Faculdade de filosofia, Letras e Ci ênci as Humanas Departamento de TeOri a Literári a e literatura Comparada

\title{
Os Malavoglia: o narrador e sua criação
}

\author{
Ana Paula freitas de Andrade
}

Tese apresentada junto à área de Teoria Literária e Literatura Comparada da Faculdade de Filosofia, Letras e Ciências Humanas da Universidade de São Paulo, sob orientação da Profa. Dra. Iná Camargo Costa, com vistas à obtenção do título de Doutor. 
Para Teresa e Amana

Agradecimentos especiais a

Homero Freitas de Andrade Iná Camargo Costa Lucia Wataghin 


\section{RESUMO}

Este ensaio propõe a obra Os Malavoglia (1881), de Giovanni Verga, como um romance-tese do Verismo, a partir do estudo de suas instâncias narrativas e da análise de seus principais procedimentos compositivos, à luz das teorias de Mikhail Bakhtin, Iúri Tyniánov, Erich Auerbach, Eleazar Meletínski e outros.

\section{Palavras-chave}

- Giovanni Verga

- Os Malavoglia

- Verismo
- Naturalismo

- Representação literária realista

- Narrador impessoal 


\section{ABSTRACT}

This essay proposes Os Malavoglia (1881), of Giovanni Verga, as roman à thèse of the Verismo, from the study of his narrative's instances and the analysis of his main compositive's proceedings, according to the teories of Mikhail Bakhtin, Iúri Tyniánov, Erich Auerbach, Eleazar Meletínski and others.

\section{KEY WORDS}

- Giovanni Verga

- Os Malavoglia

- Verismo
- Naturalism

- Realist's representantion

- Impersonal's narrator 


\section{Í NDICE}

Apresentação I

I. A formação de Verga e do Verismo 1

II. Os Malavoglia: um romance-tese? 11

III. A construção do narrador: paródia e estilização como procedimento

Bibliografia Geral 


\section{APRESENTAÇÃo}

(...) "ma per poter comprendere siffatta caparbietà, che è per certi aspetti eroica, bisogna farci piccini anche noi, chiudere tutto l'orizzonte fra due zolle, e guardare col microscopio le piccole cause che fanno battere $i$ piccoli cuori. Volete metterci un occhio anche voi, a cotesta lente? voi che guardate la vita dall'altro lato del cannocchiale?"

(G. Verga, "Fantasticheria")

Este projeto desenvolveu-se com a convicção de que Os Malavoglia (1881) são um romance-tese no qual Giovanni Verga expõe ativamente suas concepções de mundo e literatura. No plano sociocultural, a obra traça um estudo antropológico inédito da história social da Itália recém-unificada; e no literário, traz uma proposta inovadora de representação realista centrada no narrador. O romance apresenta peculiaridades estilísticas originais que propõem reformas artísticas profundas ao gênero, e demonstra um método de criação literária fecundo, que foi de suma importância para a literatura italiana.

O intuito principal deste ensaio é estudar como o autor representa a realidade no seu romance, e o foco de interesse da investigação incide sobre o narrador, pois a leitura atenta da obra levou à percepção de que ele é o manipulador de todos os procedimentos literários que dão ao leitor uma impressão de verossimilhança narrativa perfeita. Numa prática acentuadamente verista, este narrador-prestidigitador revela ao leitor o próprio processo de criação, explicitando como se constrói o tecido narrativo. E com esse gesto de narrador autodescritivo, ele desnuda os procedimentos de composição implicados em seu método de representação realista. 
O Verismo ${ }^{1}$, como vertente italiana da escola naturalista francesa, herdou a opção pela representação realista da realidade em seus estratos mais profundos e abrangentes, com a finalidade de compreender as forças que condicionam a vida humana e geram os movimentos histórico-sociais. Para Hauser, o escritor naturalista interessa-se pelas questões críticas da atualidade sociopolítica de seu país, e, lançando mão de suas convicções filosóficas e ideológicas, nutre o firme propósito quando não de sanar, de apontar, denunciar os desequilíbrios e problemas decorrentes de uma determinada situação social $^{2}$. É dessa perspectiva que Giovanni Verga, assim como os outros escritores da primeira geração verista, adota como objeto de representação literária a vida nas províncias meridionais, regida por estruturas e costumes arcaicos, afligida por antigas mazelas sociais e vítima de seqüelas do processo de Unificação italiana.

No prefácio ao romance, Verga o apresenta como o "estudo sincero e desapaixonado" das forças moventes da atividade humana que produz o progresso, especialmente da luta pelas necessidades materiais nas "baixas esferas" $^{3}$ sociais. A sua intenção é representar a realidade social contemporânea com exatidão e seriedade, valendo-se de uma observação imparcial, isenta e objetiva. O autor descreve o próprio método de criação literária ao concluir que a tarefa do observador-narrador é "restituir a cena nitidamente, com as cores devidas, de modo a dar a representação da realidade como ela foi, ou como deveria ter sido" .

No Naturalismo ${ }^{5}$, quando as classes menos favorecidas passam a ser objeto de representação literária em moldes realistas, o ideal do romance privilegia a questão da impessoalidade narrativa. $\mathrm{Na}$ escola naturalista, em que predominam o cientificismo e a intenção documental, os critérios de veracidade, isenção e objetividade orientam o método de representação artística. Novos conteúdos pedem novas formas de representação: para representar com

\footnotetext{
${ }^{1}$ Neste trabalho optou-se pela grafia do termo Verismo em itálico e com inicial maiúscula. Apesar de a palavra estar dicionarizada em português (Dicionário Houaiss da língua portuguesa, 2001), ela não aparece na forma de substantivo próprio ao designar o nome da escola literária italiana.

${ }^{2}$ Cf. A. Hauser, em Historia social de la literatura y el arte III, cit., p. 37.

${ }^{3}$ G. Verga, "Prefácio", em Os Malavoglia, cit., p. 7.

${ }^{4}$ Idem, p. 10.
} 
verossimilhança o novo objeto, o escritor precisa reformular radicalmente a maneira tradicional de narrar. ${ }^{6}$ A impessoalidade narrativa acena com a possibilidade de suprimir a distância que separa o autor-narrador e o leitor do objeto de narração, ou seja, a burguesia, do povo. No caso, o maior desafio do escritor verista consiste em criar uma representação literária que reproduza com autenticidade o mundo popular siciliano, e seja acolhida sem restrições pelo público italiano concentrado nas regiões privilegiadas do país. Em Os Malavoglia, por meio da estilização da língua falada siciliana, o escritor chega a uma solução estilística eficiente, que promove a aproximação rumo ao universo cultural popular e potencializa o efeito da verossimilhança narrativa.

No interessante ensaio introdutório à edição italiana de I Malavoglia, Edoardo Sanguineti esclarece que o ideal estético da impessoalidade narrativa fundamenta-se no mito positivista do "objeto que fala por si" ${ }^{7}$. Seu desígnio maior é sugerir ao leitor que a história se conta de per si, sem o intermédio de um narrador. Na prática, o sucesso dessa proposição reside em não se deixar entrever o narrador na matéria narrada, ou, nas palavras de Verga, fazer com que a "mão do artista"8 permaneça totalmente invisível no seu romance. É a partir dessa perspectiva, que a questão encaminhada neste estudo examina o modus operandi do narrador de Os Malavoglia, que, num movimento duplo e aparentemente contraditório, domina a narrativa por meio do simulacro da própria ausência, para que o leitor se depare com "o fato nu e genuíno". ${ }^{9} \mathrm{Na}$ medida em que o autor atribui o êxito de suas intenções literárias ao narrador, desvendar as estratégias narrativas deste segundo equivale a descobrir os procedimentos de representação da realidade articulados pelo primeiro, bem como a organicidade que lhes conferiu no interior da obra em favor da verossimilhança narrativa perfeita, que se processa a partir da ilusão da ausência do narrador. A linguagem discursiva é o único meio de que o narrador dispõe para lograr o leitor de que a sua voz é o próprio objeto artístico: a voz

${ }^{5}$ O termo é empregado aqui em sentido mais abrangente, conforme proposição de $A$. Hauser, em Historia social de la literatura y el arte III, p. 37.

${ }^{6}$ Esse narrador em terceira pessoa, despersonalizado e imparcial, surge em oposição ao velho narrador-contador de história de que trata Benjamin em seu ensaio "O narrador observações acerca da Obra de Nicolai Leskow", em Textos escolhidos, cit.

${ }^{7}$ E. Sanguineti, em "Cronologia della vita e delle opere" (Prefazione), cit., p. viii.

${ }^{8}$ G. Verga, "L'Amante di Gramigna", em Tutte le novelle, cit., p. 204.

${ }^{9}$ Idem, p. 203. 
narrativa, como representante do objeto, imita-o, em seu conteúdo e forma. Neste romance, Giovanni Verga cria uma linguagem literária a partir da estilização da língua falada da comunidade de pescadores de Aci Trezza, onde a história se passa, com todas as suas marcas socioculturais e particularidades lexicais, sintáticas, semânticas. O autor articula esta linguagem através de uma voz narrativa em terceira pessoa, portadora da voz de cada personagem e de uma voz coletiva, de senso comum, que soa livre e continuamente nas diversas modalidades do discurso (direto, indireto, indireto livre). Esta continuidade estilística, que Antônio Cândido muito bem definiu como "discurso indireto homogeneizador"10, resulta numa supressão de barreiras que iguala as vozes do narrador e das personagens num só plano discursivo.

Nessa espécie de travestimento literário da fala dialetal, ocorre um fenômeno interessante que intensifica a verossimilhança da representação da realidade no romance, porque confere naturalidade e espontaneidade ao discurso do narrador. Ao promover a mistura dos níveis de linguagens da tradição literária culta e da tradição oral popular, o autor vincula forças sociais vivas e organiza-as ativamente no interior do romance; e ao fazer com que o narrador renove as formas lingüísticas fixas do discurso, propõe a representação da realidade viva da língua, em estreita relação com a dinâmica sociocultural da comunidade retratada. No plano estrutural da obra, tais fatores colaboram para a isenção e a impessoalidade narrativas, porque atuam como mecanismos de ocultação do narrador e despersonalização das marcas ideológicas do autor.

$\mathrm{Na}$ Europa da segunda metade do século XIX, a incrementação nos setores tecnológico, industrial e comercial acelera-se e agita a vida urbana. No prefácio, Verga qualifica o seu romance como a recriação realista da realidade dos "vencidos", daqueles que, na tentativa de ascender socialmente, são engolfados pelo progresso. A história da família Malavoglia desenvolve-se num período em que, além da balbúrdia dessa nova era, conflitos internos graves abalam o país. Até mesmo na remota e esquecida Aci Trezza sentem-se os ecos do progresso, que despertam em seus habitantes "as primeiras

${ }^{10}$ Em "O mundo-provérbio", cit., p 351. 
inquietações pelo bem-estar"11; bem como o estrépito da campanha de Unificação italiana que afeta drasticamente as condições de vida da população meridional. A narração literária tradicional parece não dar mais conta de representar de modo realista este mundo em desagregação, decadência e mutação, onde as palavras e o discurso lógico escapam à compreensão, pois não conseguem abarcar a nova realidade que se impõe. Ajustar-se à demanda dos tempos para melhor representar este mundo em transformação, criando uma entidade capaz de narrá-lo com absoluta isenção e propriedade, é a principal tarefa do escritor naturalista.

No romance Os Malavoglia, Verga alcança uma resposta eficiente para essa questão do Naturalismo ${ }^{12}$, ao utilizar a paródia e a estilização ${ }^{13}$ como mecanismos de uma representação literária complexa, e de construção de um narrador impessoal inovador, apto a representar as condições da atualidade. $O$ estudo analítico desenvolvido no terceiro capítulo deste trabalho toma esses recursos como o fio condutor da investigação do método que o autor desenvolve para representar a realidade no seu romance; e pretende demonstrar como as operações paródicas são verificadas nos vários níveis estruturais da narrativa: na construção do narrador, na criação lingüística, na articulação do discurso narrativo, na enformação das personagens ${ }^{14}$, na fabulação, no desenvolvimento do enredo, na descrição de tempo e espaço, na intertextualidade etc.

O detalhe significativo do método realista de representação literária que Giovanni Verga inventou fica por conta do apelo às raízes e à ancestralidade. Em Os Malavoglia o presente é paródia do passado. O mundo moderno, de progresso rápido e idéias avançadas, só pode ser descrito com verossimilhança pela paródia do mundo antigo, estático e de pensamento absoluto. A representação paródico-estilizada ${ }^{15}$ de diversas instâncias narrativas estratifica o plano do discurso, acionando esquemas de caráter universalizante e transcendente - arquétipos, mitos, ícones, legendas, epítetos, provérbios,

\footnotetext{
${ }^{11}$ G. Verga, "Prefácio", cit., p 7.

12 Cf. G. Verga, em Lettere a Luigi Capuana, cit., p. 178 (carta de 29/ 5/ 1881).

13 Cf. I. Tyniánov, "'Dostoevskij e Gogol': per uma teoria della parodia”, em Avanguardia e Tradizione, cit., pp. 138-139.

${ }^{14}$ Cf. M. Bakhtin, em Estética da criação verbal , cit., p. 205.

${ }^{15}$ Cf. M. Bakhtin, em Questões de literatura e de estética, cit., p. 366.
} 
sabedoria popular, tradição oral, literaturas antiga, clássica e popular — que lançam o texto literário moderno em solo antigo, e consagram-lhe uma aura de elevação e perenidade. Ora, essas categorias e qualidades que a paródia introduz no romance chocam-se diretamente com os princípios positivistas e o engajamento social do Naturalismo literário nos quais a obra se fundamenta, e essa desarticulação propõe uma revisão crítica profunda da realidade artística e social.

Tudo isso leva a crer que apesar da afinidade com a escola naturalista e da colaboração decisiva para a construção do Verismo, Verga não amarrou sua produção literária nem a uma coisa e nem a outra. Avesso a rótulos, o escritor sempre se destacou por uma consciência artística independente e autônoma. Haja vista o caso de Os Malavoglia, que contemplam plenamente os preceitos naturalistas e se estabelecem na literatura italiana como obra inovadora e protótipo do romance verista, mas, ao mesmo tempo, extrapolam a própria prédica que os inspirou, porque revolucionam os padrões artísticos da época e experimentam uma "nova arte"16, antecipando a paródia como método de representação realista que caracterizaria o romance do século XX.

Nada disso faria muito sentido, se este estudo não se conduzisse pela orientação maior de reconhecer a intencionalidade da obra, e denotá-la como uma forma de percepção do mundo que está relacionada a forças históricas e condições sociais de determinado tempo-espaço. Importa ressaltar o viés ideológico do autor que, apesar de não deixar rastros evidentes na narrativa, determina o princípio de construção do romance, rege a sua organicidade e expressa uma visão de mundo autêntica e coerente. No prefácio, Verga afirma que ao narrador não cabe o direito de julgar o espetáculo que observa, e na própria premissa revela-se o contrário, pois fica claro que o narrador está desde a sua concepção munido da impostação ideológica do autor. Nesse jogo de esconde-esconde, bem caberia a seguinte pergunta: Quanto do autor há neste narrador impessoal? Uma investigação cuidadosa do romance detecta o autor justamente nos atos e momentos narrativos de maior refração: na opção pelo objeto e pelo tipo de representação artística; na invenção lingüística; na priorização dos fatos narrados, nos pontos de vista adotados neste ou naquele

${ }^{16}$ G. Verga, em “L'Amante di Gramigna”, p. 204. 
momento; nos motivos e desenlaces do enredo; nas representações paródicas; na descrição patética do tempo-espaço; no substrato cômico (a ironia) que perpassa toda a narrativa etc. Inevitável... Bakhtin explica que não há como dissociar o estilo do autor de sua posição sócio-ideológica, pois é a expressão do estilo que diferencia um autor dos outros "discursos de sua época"17.

Ao retratar o cotidiano duro e a vida desgraçada da família Malavoglia e dos habitantes da aldeia siciliana, Verga disseca aos olhos do leitor o seu objeto de estudo, reservando-se o direito, outorgado pelo escrúpulo cientificista, de não julgar as chagas sociais que expõe. No entanto, a crítica ao caso social representado dá-se de maneira indireta e oblíqua, porque o princípio de criticidade reside no próprio método de criação literária, que recorre a procedimentos paródicos para representar a realidade de forma séria. A paródia tem a intenção de mostrar o avesso dos elementos parodiados; e, assim, são engendradas na narrativa estratégias de ruptura, desconstrução, desarticulação, renovação, revolução dos padrões artísticos e axiológicos convencionais. Esta maneira de colocar as coisas revela-se bastante inteligente e democrática: Verga delega ao leitor a tarefa nada fácil de decifrar as nuances ideológicas do discurso narrativo e atribuir-Ihes sentido próprio, de um modo que, apesar de o leitor ter a impressão de fazer o percurso sozinho, caminha o tempo todo pela trilha aberta pelo narrador, e neste caso, está sempre ao lado dos "vencidos".

Nos dois primeiros capítulos deste trabalho, autor e obra são apresentados em seu contexto histórico, social e artístico, para que as projeções de um e outro sejam compreendidas no âmbito da literatura da época, e percebam-se as relações que estabelecem com a tradição literária, assim como a contribuição que oferecem para a evolução do romance moderno. Por outro lado, a ampliação do tema central tem o objetivo de estabelecer as linhas gerais que sustentam a armação teórica da tese, o estudo analítico do romance e a interpretação conclusiva do trabalho. Em italiano, dispõe-se de uma extensa fortuna crítica e inúmeros estudos biográficos sobre Giovanni Verga. No decorrer do trabalho, foram selecionados determinados materiais que melhor

${ }^{17}$ Em Questões de literatura e de estética, p. 106. 
corresponderam às intenções e prioridades de desenvolvimento de cada tópico tratado. Alguns estudos, como os de Edoardo Sanguineti, Luigi Russo, Giuseppe Petronio, Giacomo Debenedetti, Asor Rosa, Riccardo Scrivano, Corrado Simioni, Vitilio Masiello, Leo Spitzer, Nicola Merola, Gianfranco Contini ${ }^{18}$, foram essenciais e de maior utilidade para a composição dessa parte. A organização dos dados significativos da vida, formação e carreira de Verga justifica-se pelo propósito de esboçar-lhe o perfil ideológico e expor as intenções programáticas que orientaram sua criação artística. Ademais, ao considerar o fato de que a carreira do escritor e a construção do Verismo são fenômenos concomitantes e indissociáveis na literatura italiana, a exposição de cunho biográfico abrange questões relativas à filiação e ao desenvolvimento da escola literária verista; e também a suas concepções e características particulares. No que diz respeito a questões gerais da literatura européia e russa do século XIX, tomou-se por base, principalmente, os estudos teóricos de Erich Auerbach, Mikhail Bakhtin, Arnold Hauser, Antônio Cândido, Roman Jakobson, Dmitri Likhatchov, Georg Luckás; e no que concerne à literatura italiana do período, recorreu-se aos autores italianos acima citados, e ainda a tratados e compêndios específicos ${ }^{19}$.

Na produção de Verga posterior a 1874, a construção do Verismo dá-se pari passu com a experimentação de um novo tipo de narrador que desenvolva à risca e perfeição o ideal da narrativa romanesca impessoal. Foram selecionados três contos do autor que assinalam importantes etapas experimentais deste processo paulatino de construção conjunta, que culminou no romance Os Malavoglia - o qual, na opinião abalizada do mestre verista Luigi Capuana, alcançou com primazia e excelência o ideal da impessoalidade narrativa; e foi reconhecido como obra-prima do Verismo pela crítica italiana dos Novecentos. O primeiro conto é "Nedda. Bozzeto siciliano", escrito em 1874 e seis anos depois recolhido em Vita dei campi, de onde são extraídos os outros dois: "Fantasticheria" e "L'Amante di Gramigna". O exame deste material levanta temas, motivos, recursos e procedimentos de composição literária que experimentam os do romance; e dá chance a uma apresentação concisa e pertinente do método programático que o autor põe em prática na sua própria

${ }^{18}$ V. Bibliografia sobre Giovanni Verga. 
produção, com a finalidade de preparar o público para as novas concepções artísticas que defende.

O terceiro capítulo é dedicado ao detalhamento e à comprovação da proposta colocada, com análises objetivas de determinados aspectos e traços constitutivos do romance. A problemática exposta focaliza a questão do narrador como objeto central do estudo investigativo, pois entende que o seu modo de narrar determina o modelo de representação realista desenvolvido no romance e refrata as convicções ideológicas do autor. O recorte analítico incide sobre os procedimentos paródicos que reverberam em todos os estratos da narrativa, e atuam ativamente na construção do narrador, na representação realista da realidade e na concepção crítica do objeto artístico. O propósito principal dessa etapa do trabalho é compreender e elucidar tanto o método de criação do autor, quanto os elementos compositivos, a organicidade e as funções artístico-sociais do romance. As teses de Bakhtin e Auerbach compõem a base teórica sobre a qual o estudo analítico do romance se desenvolve; e são complementadas pelas teorias de outros autores, como Eleazar Meletínski, lúri Tyniánov, Antônio Cândido, Serguei Eisenstein, Walter Benjamin, Theodor Adorno $^{20}$, que tratam de questões mais específicas do tema. Na verdade, esse aparato teórico permeia todas as fases do trabalho, sua aplicação ao conteúdo imanente do romance indicou as direções de ampliação contextual da proposta; estabeleceu os campos e critérios de análise; possibilitou o aprofundamento de interpretação de cada questão abordada; e sustentou o raciocínio desenvolvido na tese, conferindo objetividade e coerência à argumentação crítica do estudo.

A interpretação do profícuo e inovador método de representação da realidade, que Giovanni Verga consumou no seu romance Os Malavoglia, leva em consideração as relações estabelecidas entre forma, estilo e sentido, e especialmente, de que modo tais componentes foram concebidos como produtos de uma história social autêntica e pertinente - o estudo literário da vida de uma comunidade de pescadores da costa oriental da Sicília, sob os efeitos colaterais da Unificação italiana. A adoção do novo objeto artístico e a necessidade de elaborar uma nova maneira de narrar que o represente em suas integridade e complexidade são fatores sobre os quais Verga se debruçou

${ }^{19} \mathrm{~V}$. Bibliografia geral: obras de teoria literária e outras. 
com afinco e chegou a uma solução estilística brilhante, que resultou em uma nova categoria de narrador romanesco. Sem perder isso de vista, importa compreender como atuam as funções artístico-sociais que esse novo tipo de romance criado por Giovanni Verga irradia. Com a realização desta proposta de estudo de Os Malavoglia, ao investigar categorias literárias interessantes, observadas em um momento crucial da trajetória de evolução do romance moderno, espera-se contribuir com um material proveitoso para o campo da Teoria literária e para a fortuna crítica do escritor.

${ }^{20}$ Idem. 


\section{A FORMAÇÃO DE VERGA E DO VERISMO}

"Io te lo ripeterò così come l'ho raccolto pei viottoli dei campi, press'a poco colle medesime parole semplici e pittoresche della narrazione popolare, e tu veramente preferirai di trovarti faccia a faccia col fatto nudo e schietto, senza stare a cercarlo fra le linee del libro, attraverso la lente dello scrittore."

(G. Verga, "L’amante di Gramigna")

Giovanni Verga publicou Os Malavoglia em fevereiro de 1881, pelo editor milanês Emilio Treves. A primeira edição do romance não alcançou o mesmo sucesso das últimas publicações do escritor siciliano. A expectativa de cinco anos de trabalho esbarrou na fria recepção de público e crítica. Dois meses após o lançamento, numa carta enviada ao amigo e também escritor Luigi Capuana, Verga queixava-se do "fracasso total" do seu romance e da indiferença do público italiano, que se dizia amante de literatura ${ }^{1}$. Pouco tempo depois, Capuana afirmava, numa resenha publicada no "Fanfulla della Domenica", que Os Malavoglia eram um romance de vanguarda, que tinha alcançado o ideal da impessoalidade narrativa, como nenhum outro romance moderno $^{2}$. E aproveitava para alfinetar o respeitado crítico Francesco De Sanctis, que acabara de publicar um estudo sobre $A$ taverna ${ }^{3}$, por não ter dado

\footnotetext{
${ }^{1}$ Em Lettere a Luigi Capuana, pp. 168-170 (carta de 11/ 4/ 1881).

${ }^{2}$ Apud C. Simioni, em "Introduzione", cit., p. 21.

${ }^{3}$ Cf. F. De Sanctis, Zola e L'Assommoir, Milano, Treves, 1879.
} 
atenção a Os Malavoglia, que, na sua opinião, mereciam como nenhum outro ter suas "belezas de primeira grandeza" ${ }^{4}$ exaltadas pelo crivo do crítico.

O silêncio da crítica e a indiferença do público, que perduraram por mais de vinte anos, podem ser creditados tanto ao caráter vanguardista atribuído à obra, como a uma série de preconceitos que sempre marcaram as relações entre o norte e o sul da península, e foram exacerbados durante o processo de assimilação das diversidades sócio-econômicas e culturais da Itália recémunificada. Certamente, a língua criada por Verga para narrar as desditas da família Malavoglia, resultado de uma ousada "sicilianização" do italiano, desgostava à crítica predominantemente conservadora da época, e afastava o público, acostumado ao italiano como padrão literário.

Somente depois da virada do século XIX, a crítica italiana "descobriu" Os Malavoglia ${ }^{5}$. Benedetto Croce dedicou-lhe um ensaio em 1903, no primeiro número de sua revista La critica $^{6}$. Uma geração de jovens escritores da década seguinte adotou o autor como mestre de "uma literatura nova"7, engajada na realidade social e moral da Itália moderna. Depois da Primeira Guerra, o romance passou a ser referido como clássico da literatura italiana, e o autor, "mestre do Verismo". Os 80 anos do escritor foram celebrados em cerimônias públicas por Luigi Pirandello e Benedetto Croce; e pouco depois, Giovanni Verga foi nomeado senador. Em 1940, a casa da família, na Catânia, foi transformada num centro de pesquisa, a "Casa Museo Verga", onde estão preservados seus manuscritos, cartas e publicações, bem como sua biblioteca, móveis e objetos pessoais. No final da Segunda Guerra, os neo-realistas elegeram-no o mais importante autor naturalista da Itália ${ }^{8}$. Em 1948, Luchino Visconti rodou La terra trema, inspirado no romance, e o filme foi premiado na IX Mostra de Veneza. A fortuna crítica do escritor é unânime ao ressaltar que suas concepções artísticas influenciaram novas levas de escritores italianos, e sua obra constitui uma rica fonte de pesquisa para artistas e estudiosos de

\footnotetext{
${ }^{4}$ Idem nota 2.

${ }^{5}$ Somente sessenta anos depois da segunda edição, Os Malavoglia foram reeditados, numa publicação das obras completas do autor organizada por Lina e Vito Perroni: Le opere di Giovanni Verga, Milano, A. Mondadori, 1940.

${ }^{6}$ Cf. "Giovanni Verga", em "La critica - rivista di letteratura, storia e filosofia". Napoli/Bari, vol. I, janeiro de 1903.

${ }^{7}$ Idem nota 2.

${ }^{8}$ Cf. G. Petronio, em L'attivitá letteraria in Italia, cit., p. 719.
} 
literatura. Atualmente, em Aci Trezza, onde a história dos Malavoglia se passa, funciona um circuito turístico-cultural.

Erich Auerbach, em Mimesis $^{9}$, faz referência ao fenômeno literário típico do final do século XIX: escritor ou obra que alcançava sucesso com rapidez, fugia à memória do público com a mesma velocidade. Todavia, se não tivessem êxito de imediato, seriam relegados ao esquecimento até o século seguinte. A obra literária inovadora arcava com a incompreensão do público e a antipatia da crítica tradicional. Esse tipo de proposta literária costumava causar estranhamento a um público pouco afeito a novidades, e tanto a compreensão da obra, como o reconhecimento de seu valor artístico processavam-se de forma lenta. Dessa perspectiva, a resposta dos leitores contemporâneos à obra pode ser observada como o reflexo imediato das funções artístico-sociais que ela irradia, e que, de uma maneira ou de outra, influencia o processo de incorporação do romance ao patrimônio literário do país. E assim cumpriu-se o destino de Os Malavoglia, que amargaram o fracasso antes de serem reconhecidos obra-prima do Verismo.

As condições da estréia do romance e a receptividade do público sobretudo o burguês, que o escritor, desde que estabilizara sua carreira profissional nos centros culturais mais importantes da época (Florença e Milão), vinha didaticamente preparando para as concepções do Naturalismo configuram-se como uma primeira resposta ao romance inaugural de um grande projeto literário, no qual Verga pretendia desenvolver um estudo de caráter sócio-antropológico da sociedade italiana do final do século XIX.

Esse breve histórico suscita alguma reflexão, para que sejam esboçadas as projeções do autor e da obra nos domínios da literatura da época, de modo a evidenciar as relações que estabelecem com a tradição literária, bem como as propostas que apresentam para a evolução do romance moderno. Por que o romance é considerado obra de vanguarda na literatura italiana? Quais são as inovações artísticas que ele propõe ao gênero? De que modo o ideal da impessoalidade narrativa foi alcançado? Como a realidade social da Itália é representada nesta obra?

${ }^{9}$ Cf. op. cit., pp. 449-450. 
Se a carreira de Verga e a construção do Verismo são adventos concomitantes numa Itália em processo de unificação, alguns elementos extraliterários, tais como aspectos da vida familiar e da formação intelectual do escritor, sua orientação filosófica e postura ideológica, sua participação na vida literária, as concepções que nortearam sua criação também podem trazer subsídios para uma melhor compreensão do caráter experimental da obra em estudo.

Giovanni Carmelo Verga nasceu aos 2 de setembro de 1840 em Catânia, na costa oriental da Sicília. A família do pai, Giovanni Battista Verga Catalano, tinha ascendência ibérica. Eram os Vergas, "cavalieri di diritto" e grandes proprietários de terras na região. O avô paterno fora líder da Carbonária de Vizzini e deputato do Parlamento siciliano ${ }^{10}$. A família da mãe, Caterina Di Mauro, pertencia à burguesia catanesa. Em casa, a mãe, além dos livros de devoção, cultivava a leitura de obras consagradas e de literatura amena. $\mathrm{Na}$ adolescência, Giovanni Verga freqüentou o instituto de Dom Antonio Abate, poeta romântico, cantor de temas patrióticos e ideais republicanos; o mestre fazia os alunos lerem Dante, Petrarca, Ariosto, Tasso, Monti, Manzoni, e também escritores populares meridionais, especialmente Domenico Castorina ${ }^{11}$. Nessa época, o jovem também tomava lições de latim e filosofia. Aos 16 anos concluiu sua primeira narrativa de cunho histórico intitulada Amore e Patria, um manuscrito de 672 páginas sobre a Insurreição de 1848, em que o próprio Abate combatera.

Em 1860, cursava direito na Universidade de Catânia, quando a "Guardia Nazionale" foi instituída na cidade por Giuseppe Garibaldi, que liderava a Expedição dos Mil, em campanha bélica no reino das Duas Sicílias, com o objetivo de subtraí-lo ao poder dos Bourbons. O serviço militar era obrigatório e Giovanni Verga serviu na I Legião por quatro anos. Durante este tempo, foi leitor entusiasmado de romances históricos, especialmente dos italianos Massimo D'Azeglio, Francesco Domenico Guerrazzi; dos franceses Dumas, Eugène Sue, Feuillet; e do inglês Walter Scott ${ }^{12}$. Em 1861, deixou a universidade e passou a se dedicar intensamente ao jornalismo. Ao lado de Antonino Abate e Niccolò

\footnotetext{
${ }^{10}$ Cf. Dizionario biografico degli Autori di tutti i tempi, cit., p. 394.

${ }^{11}$ Cf. E. Sanguineti, em "Cronologia della vita e delle opere", p.xvii.

${ }^{12}$ Cf. www.volpin.it.
} 
Niceforo, fundou e dirigiu "Roma degli italiani", "Italia contemporanea" e "L'independente", jornais engajados na luta republicana e unionista. No mesmo ano, publicou por conta própria o romance I carbonari della montagna, em que retrata a ação da Carbonária calabresa nos anos de 1820 contra a espoliação napoleônica das Duas Sicílias. Em 1863, a revista florentina "Nuova Europa" publicou em capítulos Sulle lagune, um romance epistolar ambientado em Veneza, durante a resistência ao império austríaco.

A família, o mestre, as leituras, a experiência como soldado e jornalista militante são elementos significativos na produção do jovem Giovanni Verga: Amore e patria é o lema poético-ideológico do romântico Antonino Abate; I carbonari della montagna penetra a sociedade secreta de que fizeram parte o avô paterno e o comandante Giuseppe Garibaldi; a história de Sulle lagune se desenvolve sob o regime da guerra entre a guarda italiana e o invasor estrangeiro. São romances inspirados em acontecimentos de projeção nacional e relevância histórica. O autor se interessa pela problemática político-social de sua pátria e seu tempo; e está sintonizado com tendências artísticas vindas da França, que desde as primeiras décadas dos Oitocentos atuam na formação de uma literatura pautada em idéias socialistas e interessada pelas questões críticas do século ${ }^{13}$.

A partir da segunda metade do século XIX, em toda Europa ocidental, ocorre uma crescente concentração populacional nos centros urbanos. Como explica Hauser ${ }^{14}$, o processo de urbanização da sociedade européia acelera-se a passos largos; o capitalismo permeia todas as relações sociais e uma série de mudanças transforma radicalmente a vida cotidiana nas grandes cidades. Um arsenal tecnológico e industrial inova diversos setores, como os meios de transporte e de comunicação; as condições de moradia, educação e saúde; o comércio, as finanças, os produtos alimentares e de vestuário, as opções de lazer $^{15}$. A conjunção desses fatores favorece, como nunca antes ocorrera, o acesso da população à educação e o aprimoramento das técnicas de imprensa, os quais, por sua vez, incrementam a circulação de material jornalístico e

${ }^{13}$ Cf. A. Hauser, em Historia social de la literatura y el arte III, pp. 30-31; e E. Auerbach, em Mimesis, pp. 453-454.

${ }^{14}$ Em Historia social de la literatura y el arte III, pp. 11-130 (tema tratado nos dois primeiros capítulos do livro).

${ }^{15}$ Idem, pp. 79-80. 
literário. Cresce o número de leitores: a sociedade urbana encontra-se capacitada e sequiosa por leitura ${ }^{16}$. Para Saint-Beuve, esta é a era da "industrialização da literatura" ${ }^{17}$ - um período revolucionário quando começa a se consolidar um mercado editorial abrangente e promissor, que determina um novo rumo para a produção literária. A demanda dos novos tempos pede urgentemente que os escritores se profissionalizem, pois somente assim a categoria literária pode se constituir como segmento representativo da sociedade, e desempenhar uma função social definida.

$\mathrm{Na}$ Itália, os dois pólos urbanos mais receptivos ao progresso são Florença e Milão - cidades em que a vida urbana é agitada, produtiva e aberta às novas tendências artísticas e culturais vindas do estrangeiro, principalmente da França. Desde que abandonara os estudos universitários, Giovanni Verga tinha resolvido dedicar-se somente à literatura e abraçar a carreira profissional de escritor. Foi com esta determinação que em 1865 viajou pela primeira vez para Florença, munido de uma carta de apresentação do amigo de infância e poeta Mario Rapisardi, endereçada ao influente literato Francesco Dall'Ongaro. Verga foi muito bem recebido, e logo introduzido nos circuitos culturais e artísticos. Permaneceu dois meses na cidade e foi apresentado a escritores, músicos, pintores, escultores, atores, ativistas políticos ${ }^{18}$. No decorrer dos quatro anos seguintes, viajou constantemente para lá. Numa dessas estadas, em 1869, conheceu o escritor siciliano Luigi Capuana, que à época era crítico teatral do jornal "Nazione". Tinha início ali uma duradoura amizade, fortalecida pela reciprocidade de convicções literárias. Uma "bendita camaradagem artística e moral", escreveria Verga numa carta ao amigo, fundamentada em um mesmo ideal, que motivou os projetos literários da dupla, e era, nas palavras do escritor, "nossa 'cruz e delícia"”19.

Em novembro de 1872 Verga chegou a Milão, levando na bagagem cartas de apresentação para duas personalidades influentes no meio literário e editorial — uma de Capuana para Salvatore Farina, e outra de Dall'Ongaro para

${ }^{16}$ Cf. E. Auerbach, em Mimesis, p. 450.

${ }^{17}$ Apud A. Hauser, em Historia social de la literatura y el arte III, p. 27.

${ }_{18}^{18} \mathrm{Cf}$. E. Sanguineti, em "Cronologia della vita e delle opere", p.xix.

${ }^{19} \mathrm{Em}$ Lettere a Luigi Capuana, pp. 112-113 (as duas citações, respectivamente; carta de 14/ 3/ 1879). 
Tullo Massarani $^{20}$. Estabeleceu-se na cidade, onde morou por vinte anos, durante os quais, não deixou de passar longas temporadas na Sicília. Milão, chamada de "capital moral" da Itália, destacava-se pelo franco progresso do comércio e da indústria, e pela intensidade de sua vida urbana e cultural. As atividades artísticas, especialmente literárias, fervilhavam nos cafés e nos salões da burguesia, onde Giovanni Verga conheceu diversos escritores renomados e promissores da época ${ }^{21}$. Na década de 1860, a cidade, que mais tarde seria o berço do Verismo, viu nascer a Scapigliatura, movimento literário de cunho anticonformista; avesso a moral, política, religião e retórica vigentes; e que em suas obras representa o cotidiano das pessoas que vivem à margem e a serviço da burguesia. Verga travou amizade com seus principais representantes e simpatizantes, como Luigi Gualdo, Arrigo Boito, Emilio Praga, Giuseppe Giacosa, Giovanni Camerana, Felice Cameroni. Neste período dedicava-se à leitura de Balzac, Flaubert, Maupassant, Daudet, os irmãos Goncourt, Zola - escritores cujas obras também eram os temas centrais das discussões que animavam as rodas intelectuais e artísticas. A conexão com a vida literária francesa era bastante intensa, e certamente fez chegar ao circuito milanês obras de alguns expoentes da literatura russa, sobretudo Gógol, Dostoiévski e Lev Tolstói ${ }^{22}$, cujas traduções francesas à época circulavam febrilmente entre a elite intelectual parisiense.

Entre 1866 e 1876, Verga publicou Una peccatrice (1866), Storia di una capinera (1870), Eva (1873), “Nedda, bozzetto siciliano” (1874), Eros (1875), Tigre reale (1875) e Primavera e altri racconti (1876). Essas obras compõem a chamada fase florentina do escritor, e várias delas fizeram sucesso junto aos leitores, alcançando tiragens bastante elevadas. Storia di una capinera colocou Giovanni Verga no rol dos "escritores da moda" ${ }^{23}$, e durante mais de cinqüenta anos cativou em especial o público feminino ${ }^{24}$.

${ }^{20}$ Cf. N. Merola, em Giovanni Verga, cit., p. 20.

${ }^{21}$ Cf. E. Sanguineti, em "Cronologia della vita e delle opere", p. xx.

22 Segundo Auerbach (Mimesis, p. 467), as obras de Dostoiévski e Tolstói entraram na Europa a partir da década de 1880. Já G. Contini (Letteratura dell'Italia unita - 18611968, cit., p. 141) afirma que Verga teria lido autores russos, antes de publicar Os Malavoglia.

${ }^{23}$ G. Petronio, em L'attivitá letteraria in Italia, p. 709.

${ }^{24}$ Cf. L. Russo, em Gli scrittori d'Italia - storia della letteratura italiana - v. II, cit., p. 753. 
O jovem Verga é um autor cosmopolita, cuja narrativa retrata principalmente o mundo elegante da alta burguesia italiana oitocentista. $\mathrm{Na}$ opinião de Luigi Russo, a sua produção deste período acompanha a revolução moral da sociedade e a transição literária da última metade do século ${ }^{25}$. Tendências anti-românticas eram importadas da França. Carducci e De Sanctis diagnosticavam que o público italiano fora envenenado pelo romantismo de Victor Hugo e Heine, além de se encontrar saturado de "séculos de petrarquismo"26. Os textos de Verga, de ambientação urbana (exceto "Nedda"), expõem costumes, convenções e dogmas da sociedade burguesa contemporânea, a ponto de desnudá-la e submetê-la a uma análise incisiva ${ }^{27}$. Em termos de composição literária, o processo se dá por meio de um mecanismo sincrônico de resgate e liquidação de motivos do Romantismo ${ }^{28}$, tais como a sujeição ao amor, o desvario da paixão ou a fantasia erótica exacerbada. As tramas, encabeçadas por personagens femininas, traçam uma representação romântica da psicologia da mulher, em suas reações às convenções artificiais inerentes a seu papel cotidiano na vida em sociedade. São, por assim dizer, crônicas sociais, e mais especificamente, ensaios sóciofisiológicos da figura feminina, tais quais outros grandes escritores do século também os fizeram, como Flaubert, Maupassant, Zola, Turgueniev.

O romance Eva, por exemplo, escandalizou a crítica tradicional da época. Em uma resenha anônima da "Nuova Antologia" Verga foi acusado de ter apelado a uma realidade sórdida e à sensualidade despudorada. ${ }^{29} \mathrm{O}$ enredo desenvolve a história da paixão obsessiva de um jovem siciliano por uma bailarina da cidade grande, que encara corajosamente a própria condição. Já os menos radicais viram na obra um forte acento "scapigliato", e, de fato, ao se deixar de lado o falso pudor, a segunda avaliação faz muito mais sentido, pois decifra a tônica predominante no romance, afinada com determinados preceitos da Scapigliatura, que, com maior ou menor intensidade, estão presentes também nas outras produções florentinas do autor. Eva investe no tom

\footnotetext{
${ }^{25}$ Idem, pp. 767-71.

${ }^{26}$ Apud G. Petronio, em L'attivitá letteraria in Italia, p. 710.

${ }^{27}$ Cf. G. Petronio, em L'attivitá letteraria in Italia, p. 709; e L. Russo, em Gli scrittori d'Italia..., pp. 763-67.

${ }^{28}$ Cf. L. Russo, em Gli scrittori d'Italia..., p.754.

${ }^{29}$ Cf. E. Sanguineti, em "Cronologia della vita e delle opere", p. xx.
} 
"scapigliato", ao desenvolver o tema da obsessão erótica, narrar o cotidiano de pessoas que vivem à margem da alta sociedade e descrever ambientes degradados, escancarando os falsos pudores da burguesia. No prefácio provocador que escreveu para o romance, Giovanni Verga denuncia a hipocrisia que sustenta a moral burguesa. $O$ autor se dirige a um interlocutor virtual, o leitor burguês, pedindo-lhe que não condene a arte que mostra o avesso de seus prazeres mundanos; não subestime a dor e o sofrimento daqueles que servem ao deleite dos ricos; e não pregue a moralidade, uma vez que "fecha os olhos para o espetáculo da miséria que criou" e ainda se espanta com quem deixa "o coração e o amor"30 onde só se costuma deixar o dinheiro.

$\mathrm{Na}$ contramão da opinião da crítica conservadora, Verga comentou numa carta de 1875 a Felice Cameroni ${ }^{31}$ que sempre procurou ser simplesmente verdadeiro - e não realista, idealista ou romântico —, e fora exatamente com esta intenção que escrevera seus romances. Tal declaração sugere que, à revelia de qualquer rótulo artístico, em sua práxis literária o autor buscava a veracidade, o "rigor da análise psicológica" e "a eficácia que nasce da representação viva do fato" ${ }^{\prime 2}$. Os romances da sua fase florentina desvendam, uns de maneira mais bem-sucedida do que outros, as verdades estratificadas da sociedade italiana privilegiada, por meio da desconstrução de velhos mitos e símbolos do romantismo tardio; e esse mecanismo de desmitificação experimenta procedimento artístico característico da escola naturalista. Segundo Hauser, na literatura naturalista francesa coexistiam duas tendências diferentes: uma de escritores boêmios, que na Itália inspirou a Scapigliatura; e outra de capitalistas, encabeçada por escritores como Flaubert e os irmãos Goncourt $^{33}$, que influenciou o Verismo.

Luigi Russo ressalta ainda que esta produção é um capítulo importante da formação ideológica e estética da poética de Verga, pois reflete a participação do jovem escritor no espírito e na experiência psicológica do século ${ }^{34}$. No âmbito da história da literatura italiana, trata-se de um período de transição, quando manifestações literárias inovadoras, como as da Scapigliatura ou as

\footnotetext{
${ }^{30}$ Apud G. Petronio, em L'attivitá letteraria in Italia, p. 709.

${ }^{31}$ Cf. Wikipedia, l'enciclopedia libera: "Giovanni Verga - biografia".

${ }^{32}$ G. Verga, em Lettere a Luigi Capuana, pp. 125-126 (carta de 18/ 6/ 1879).

${ }^{33}$ Cf. A. Hauser, em Historia social de la literatura y el arte III, p. 84.

${ }^{34}$ Em Gli scrittori d'Italia..., p. 767.
} 
primeiras narrativas nos moldes naturalistas, impõem-se aos desgastados clichês do Romantismo. Uma nova geração de escritores concentrada no eixo Milão-Florença, cujos representantes mais pertinazes são Luigi Capuana e Giovanni Verga, começa a trabalhar ativamente na construção do Verismo, procurando elaborar um método de representação literária realista, orientado pela estética do Naturalismo francês, mas ajustado aos conteúdos da realidade italiana, verificáveis nos processos sociopolíticos e culturais da atualidade. 


\section{II}

\section{OS MALAVOGLIA, UM ROMANCE-TESE?}

"Il bello era a sentirlo raccontare le sue aventure: e finiva sempre col dire le gran cose che ci aveva imparate, per governarsi meglio in avvenire. - Ho imparato -, diceva, - a non mettermi ne' tumulti: ho imparato a non predicare in piazza: ho imparato a guardar con chi parlo: ho imparato a non alzar troppo il gomito: ho imparato a non tenere in mano il martello delle porte, quando c'è lì d'intorno gente che ha la testa calda: ho imparato a non attaccarmi un campanello al piede, prima d'aver pensato quel che ne possa nascere. - E centr'altre cose.

Lucia però, non che trovasse la dottrina false in sé, ma non n'era soddisfatta; le pareva, così in confuso, che ci mancasse qualcosa. A forza di sentir ripetere la stessa canzone, e di pensarci sopra ogni volta, - e io, - disse un giorno al suo moralista, cosa volete che abbia imparato? lo non sono andata a cercare i guai: son loro che son venuti a cercar me. Quando non voleste dire, - aggiunse, soavemente, sorridendo, - che il mio sproposito sia stato quello di volervi bene, e di promettermi a voi.

Renzo, alla prima, rimase impicciato. Dopo un lungo dibattere e cercare insieme, conclusero che $i$ guai vengono bensì spesso, perchè ci si è dato cagione; ma che la condotta più cauta e più innocente non basta a tenerli lontani, e che quando vengono, o per colpa o senza colpa, la fiducia in Dio li raddolcisce, e li rende utili per una vita migliore. Questa conclusione, benchè trovata da povera gente, c'è parsa così giusta, che abbiam pensato di metterla qui, come il sugo di tutta la storia."

(A. Manzoni, I promessi sposi.)

Desde meados da década de 70, a dupla Verga e Capuana participava ativamente da vida artístico-intelectual milanesa, divulgando materiais literários de caráter naturalista, de origens francesa, inglesa e russa. Quando não estavam na mesma cidade, os dois amigos mantinham intensa correspondência entre si e também com outros literatos expressivos da época - 
Felice Cameroni, Salvatore Farina, Emilio Treves, e integrantes do grupo dos "scapigliati" - , em que discutiam as novas idéias literárias, e as maneiras de aplicá-las à própria criação artística, adaptando-as ao contexto sócio-cultural italiano. O plano de elaborar uma versão nacional da literatura naturalista assumira importância capital na vida dos dois escritores sicilianos, e sua atuação, juntamente com um grupo de colegas mais chegados, fez com que o Verismo começasse a adquirir contornos próprios e padrões definidos. Luigi Capuana, chamado "profeta do Naturalismo", empenhou-se especialmente em promover a obra de Zola e difundir suas concepções literárias. É autor de Giacinta, publicado em 1879 e reconhecido como o primeiro romance verista; e escreveu uma série de ensaios, estudos e artigos sobre a temática naturalista.

Segundo Hauser, a principal fonte da doutrina naturalista foi a experiência política frustrante da geração de 1848 , em conseqüência do insucesso da Revolução, da repressão à Insurreição de Junho e da subida ao poder do déspota Luís Napoleão. $\mathrm{O}$ fracasso dos ideais e das utopias democratas fez com que os escritores tomassem para si a missão política de fazer algo significativo por meio de suas penas. Num processo constante de luta contra o espírito idealista e individualizante do Romantismo, adepto à fuga da realidade e ao princípio burguês da "arte pela arte", o escritor naturalista assume com entusiasmo a função de educador, com a finalidade de reformar a sociedade e influenciar o seu futuro real ${ }^{35}$. O engajamento social e a diretividade didática da escola naturalista entendem que a maneira prática de intervir nos processos sócio-políticos de seu tempo é promover a educação do leitor, e mais amplamente, do ser humano ${ }^{36}$. Em suma, conforme explica Antônio Cândido, o escritor do século XIX procura explorar o ativismo da obra literária, a fim de granjear esferas de influência na sociedade, cultivar seu público e provocar mudanças no comportamento dos grupos sociais, que levem a uma redefinição das relações entre os indivíduos ${ }^{37}$.

Mikhail Bakhtin, em Questões de literatura e de estética, traça a trajetória de formação do romance ${ }^{38}$ e observa que os cânones de gêneros literários

\footnotetext{
${ }^{35} \mathrm{Em}$ Historia social de la literatura y el arte III, pp. 83-91.

${ }^{36}$ Cf. E. Auerbach, em Mimesis, pp. 443-470.

${ }^{37} \mathrm{Em}$ Literatura e sociedade, cit., p. 74.

${ }^{38}$ Em Questões de literatura e de estética..., especialmente no capítulo: "Epos e romance".
} 
acabados que o precederam contribuem como força histórica real neste processo. A certa altura, o autor afirma que desde o lluminismo, o romance moderno estava aberto para o "estabelecimento do livre conhecimento científico e para a criação artisticamente realista da humanidade européia" ${ }^{\prime 3}$. Esta tendência ganha força no Romantismo, quando a representação literária privilegia as particularidades sócio-geográficas — o artista romântico, movido por certa disposição ideológico-emocional, explora temas natais, projetando-os no tempo histórico local. No entanto, é na escola naturalista que tal orientação encontra maior expressividade e ganha significação mais profunda, pois se incorpora como princípio ético da criação artística. Na tentativa de investigar e compreender as idéias que impulsionam o mundo, as forças que condicionam as circunstâncias espirituais, econômicas, culturais da vida diária e geram os movimentos histórico-sociais, a expressão literária naturalista privilegia a representação da realidade em seus estratos mais profundos e abrangentes. No âmbito da literatura européia, Balzac, Stendhal e Flaubert, bem como Gógol na literatura russa, introduzem como protagonista da narrativa romanesca 0 "homem sem importância", de que fala Meletínski ${ }^{40}$, representado em seu próprio ambiente, devidamente condicionado às circunstâncias histórico-sociais que o determinam ${ }^{41}$. Antes, o homem comum, camponês, serviçal ou artesão, figura na literatura tão-somente como personagem cômica ou modelo idealizado de bondade humana, pertencente à base da pirâmide social. Tudo o que diz respeito a sua realidade cotidiana não recebe tratamento artístico sério, tolhendo-se desse modo toda e qualquer possibilidade de aprofundamento problemático das circunstâncias representadas, já que não são abordadas as verdadeiras forças que as movem e nem os reais valores que as permeiam.

O Naturalismo, como tendência dominante na última metade do século XIX, impulsiona a renovação do gênero romanesco, que passa a ter como objeto de representação o universo da gente sem importância, e, com isso, revoluciona a própria língua literária. Um imenso repertório lingüístico, que até então atentava contra os cânones estabelecidos, começa a adquirir dignidade literária, ao tornar-se instrumento para a representação realista desse universo.

\footnotetext{
${ }^{39}$ Idem p. 414.

${ }^{40}$ Em Os Arquétipos Literários, cit., p. 222.

${ }^{41}$ Cf. E. Auerbach, em Mimesis, p. 408.
} 
Ao enfocar a vida da gente comum, retratando suas mazelas pessoais e coletivas, o escritor naturalista expõe as desigualdades e injustiças que alicerçam toda a estrutura da sociedade, desperta o senso crítico do leitor e colabora para sua "conscientização". Este, segundo Auerbach, é um recurso de composição "intra-histórica" da obra literária, que contribui de maneira eficaz para o desenvolvimento da "auto-responsabilização social do homem"42.

Na opinião de Hauser, tais circunstâncias foram essenciais para fomentar na literatura a luta consciente de classes, pois pela primeira vez os estratos inferiores eram retratados de maneira fidedigna como representantes de uma camada social privada de seus direitos ${ }^{43}$. A aguçada consciência sociopolítica da escola naturalista caracteriza a sua expressão artística como de oposição e engajamento social. O escritor naturalista, interessado pelo estudo do processo histórico do ponto de vista das baixas esferas, volta sua atenção para questões cruciais e polêmicas da realidade social e política do seu país ${ }^{44}$. Tome-se como exemplo os romances franceses mais característicos do Naturalismo que versam a temática da civilização burguesa e focalizam principalmente as classes sociais desfavorecidas do ambiente citadino: os trabalhadores urbanos e o operariado industrial. Já na Itália, que vive um processo de unificação política conturbado, e onde a urbanização e a industrialização desenvolvem-se de forma desigual nas regiões norte e sul, é a sociedade rústica e atrasada das províncias sicilianas que atrai o olhar dos escritores veristas.

Com a publicação do conto "Nedda", em 1874, na Rivista italiana di Scienze, Lettere ed Arti de Milão ${ }^{45}$, Verga inaugura o principal filão temático do Verismo, a vida de camponeses e pescadores nas províncias sicilianas, durante o período da Unificação italiana, sob condições de sobrevivência extremamente precárias. O Verismo nasce milanês, com alma siciliana referendada pelas penas de Verga, Capuana e posteriormente, De Roberto. Ao longo de sua existência produtiva que se estende até o primeiro decênio do século $X X, 0$ Verismo conquista escritores e temas de outras regiões italianas, como Serao e Di Giacomo de Nápoles; Deledda da Sardenha; Misasi da Calábria; Fucini,

\footnotetext{
${ }^{42}$ Em Mimesis, p. 430 (as duas citações do período).

${ }^{43}$ Em Historia social de la literatura y el arte III, p. 46.

44 Idem, p. 37.

${ }^{45} \mathrm{O}$ conto foi publicado originalmente na revista, em 15/ 6/ 1874.
} 
Lorenzini e Pratesi da Toscana; Cagna, Giacosa, De Marchi, De Amicis do Piemonte; Dall'Ongaro e Caterina Percoto do Vêneto.

Em meio à produção florentina de Verga, em que predominam a representação da vida da sociedade burguesa e a ambientação na cidade grande, distingue-se o bucólico "Nedda". No conto, o autor explora um novo cronotopo literário: o mundo popular da província siciliana na era pós-unitária; e isto Ihe garante a primazia de experimentar, mesmo que de maneira ainda pouco aprofundada, tendências artísticas, elementos narrativos e técnicas de composição que viriam a se estabilizar no repertório da literatura verista: a apropriação de temas e motivos culturais populares, a reprodução da linguagem falada regional na prosa literária, a descrição minuciosa dos costumes e do cotidiano do homem comum, o desenvolvimento do enredo narrativo de acordo com princípios de dois sistemas filosóficos relevantes do século XIX, o positivismo, de Auguste Comte e, especificamente no caso de Verga e seus epígonos, o pessimismo, de Arthur Schopenhauer.

O narrador dá início à fabulação com um breve prólogo em primeira pessoa, por meio do qual prepara o leitor, burguês como ele, para o espetáculo de "atmosferas desconhecidas" ${ }^{46}$ que o deixará com cabelos brancos e rugas no rosto. Numa confortável poltrona, o narrador se aquece junto à lareira, e convida o leitor a acompanhar o seu espírito que vagabundeia por caminhos inusitados até chegar a uma pequena propriedade rural nas proximidades do Etna, onde a história tem início. É um lugar miserável, povoado de personagens paupérrimas, como a protagonista Nedda, a mais desgraçada de todas. Por meio desta introdução, o narrador simula um serão ao redor do fogo doméstico, e se traveste de contador de "causo". O tema de sua história é a luta desigual da protagonista contra a miséria e a morte, que paulatina e impiedosamente vão Ihe tomando os entes mais próximos - a mãe, o namorado, a filha recémnascida —, até a deixarem totalmente só e desamparada. Tanto a encenação inicial armada pelo narrador, quanto o tema da história evocam os tradicionais serões invernais entre familiares, amigos e vizinhos, em que eram desfiados os "racconti di veglia", contos maravilhosos, frutos da cultura popular apenínica, que geralmente têm por tema a visita da morte.

${ }^{46}$ G. Verga, em "Nedda", Tutte le novelle, cit., p.14. 
A abertura do conto, impregnada de um lirismo aconchegante, funciona como uma espécie de ante-sala da história a ser narrada, uma zona neutra em que o narrador, em primeira pessoa, preserva o leitor e a si mesmo a uma cautelosa distância do universo real que ele passará a narrar, assumindo então uma voz em terceira pessoa, que garante certo distanciamento do objeto de narração. É como se, à realidade crua e mísera só fosse permitido o tratamento literário sério por meio deste processo de adequação, em que uma história incômoda é revestida de uma outra aprazível que a justifica.

Embora o conto descreva determinada faceta da sociedade siciliana sob este forte acondicionamento romântico, que faz com que o narrador se mantenha diferenciado do mundo que representa, e confronte constantemente realidade e idealidade, a narrativa experimenta alguns princípios e recursos compositivos característicos da escola naturalista francesa, desde já temperados à moda italiana. A começar pelo papel de protagonista concedido a uma camponesa do mais baixo escalão de sua classe social, Nedda vive de expedientes, nem sempre consegue trabalho, não tem como comprar os remédios para a mãe doente, e nem sequer o pão de cada dia. O retrato dessa comunidade arcaica é traçado de acordo com o método desenvolvido por Balzac na década de 1830, e por ele definido como "estudos dos costumes", cuja principal característica é a descrição minuciosa de hábitos e usos do tempo presente, "com tudo o que tiver de cotidiano, prático, feio e comum" ${ }^{\text {"77 }}$ para que possam ser compreendidas as forças históricas que levaram a vida humana à condição atual. E Verga faz algo similar, ao descrever a comunidade siciliana, retratando as agruras do trabalho no campo, a parca refeição no fim do dia, as conversas de poucas palavras, orientadas pela lógica do senso comum, o comportamento das pessoas regido pela fé cega nos preceitos da doutrina cristã.

No conto, predomina a forma narrativa convencional (do narrador burguês que conta a história ao pé da lareira), e a representação da língua falada do grupo social retratado se dá pela reprodução de algumas expressões dialetais, termos específicos do trabalho agrário, o trecho de uma cançoneta popular e alguns provérbios da região, que, tanto no discurso direto, quanto no indireto,

${ }^{47}$ E. Auerbach, Mimesis, p. 430. 
aparecem destacados por grifo - recurso que em boa medida resguarda 0 nível culto da língua literária, sem deixar de apresentar uma amostra da língua local.

A representação da hierarquia da comunidade social em foco obedece aos critérios da lei darwinista de seleção natural — no dia de pagamento do trabalho da semana, diante da mesa do feitor, recebem-no primeiramente os homens turbulentos, em seguida as mulheres briguentas e por último as tímidas e fracas. A equiparação entre seres humanos e animais é recorrente na narrativa, Nedda parece um passarinho assustado, corre feito uma cabrita tresmalhada ou trabalha como uma formiga, e seu namorado migra de cá pra lá como a cotovia em busca de milho. A sucessão ininterrupta de desgraças que culmina no trágico desenlace da história, quando a pobre protagonista termina num perturbador estado de resignação ao sofrimento da vida, já engendra a lógica pessimista, típica do Verismo, que, grosso modo, sustenta a idéia de que os aspectos negativos da existência prevalecem sobre os positivos. Há que se ressaltar ainda ao menos dois conceitos da filosofia positivista que atuam como princípios organizadores da estrutura narrativa do conto: o método da observação científica, que examina todos os detalhes do objeto sem deixar de lado aspectos pouco agradáveis, e a convicção de que o meio físico determina a vida humana.

Entre 1875 e 1880 Giovanni Verga trabalhou concomitantemente na redação do romance Os Malavoglia, e de vários contos que, depois de publicados em periódicos, foram reunidos em Primavera e altri racconti, de 1876; e Vita dei Campi, de $1880^{48}$. Sem perder de vista a produção do amigo, Capuana bem notou que depois dos contos dessa segunda coletânea, Nedda não estava mais só, pois o romancista da vida elegante da cidade tinha retornado para "os campos da sua Sicília"49 e criado um numeroso elenco de personagens típicos que Ihe fariam companhia, como o compadre Turiddu Macca, sua mãe nhá Nunzia, o carreteiro Alfio e sua mulher Lola, o feitor Cola e sua filha Santa, de "Cavalleria rusticana"; o brigante Gramigna, a Peppa e o compadre Finu, de "L'Amante di Gramigna"; o Pentolaccia, sua Venera e a outra

\footnotetext{
48 Sobre os periódicos e as datas em que os contos de Vita dei campi (1880) foram publicados originalmente, cf. C. Riccardi, em "Introduzione", cit., p. xi.

${ }^{49}$ Apud, www.volpin.it (fonte: Enciclopedia Alfatematica - Microforum - Peruzzo Informatica.)
} 
ponta do triângulo amoroso, dom Liborio, de "Pentolaccia"; o Malpelo, seu pai, o mestre Misciu Bestia, sua mãe Nunziata e o companheiro Ranocchio, de "Rosso Malpelo"; e tantos outros.

A opção do autor por explorar argumentos de um novo campo sociocultural implica a criação de novos padrões estéticos, soluções estilísticas e recursos narrativos que os comportem, e representem o novo objeto literário com propriedade. Bakhtin explica que ao serem introduzidos conteúdos inéditos nos domínios da literatura, desencadeia-se uma crise na criação estética que leva à superação da própria arte $^{50}$; e dessa perspectiva, entende-se que ao colocar em prática as concepções artísticas que defendia, Verga contribuiu não somente para a construção do Verismo, como também para a renovação dos próprios fundamentos da "literaturidade e da poeticidade dominantes" ${ }^{\text {"51 }} \mathrm{em}$ seu país. O conto "Nedda" configura-se como o de anúncio do rompimento das convenções vigentes na literatura italiana da época, porque agrupa em gérmen as propostas de inovação da criação literária, as quais, ao longo dos anos subseqüentes, seriam desenvolvidas nas obras veristas e passariam a fazer parte do preceituário do Verismo.

Dois outros contos de Vita de Campi constituem material precioso para o estudo não só do processo de elaboração dos métodos de representação verguianos, como também da própria trajetória de formação da escola na Itália. Trata-se de "Fantasticheria" e "L'Amante di Gramigna"52. Além desses contos, as várias etapas de criação de Os Malavoglia consubstanciam a experimentação do escritor em busca do narrador impessoal perfeito, ao mesmo tempo em que dão uma amostra de suas reflexões acerca do significado e funcionalidade das proposições artísticas, de caráter naturalista, que iriam revolucionar os padrões axiológicos, éticos e estilísticos da literatura italiana nas últimas décadas do século XIX.

O conto "Fantasticheria", além de antecipar o argumento desenvolvido no romance Os Malavoglia, é documento importante da poética verista, dado que experimenta temas, motivos, recursos e procedimentos artísticos que

${ }^{50}$ Em Estética da criação verbal, pp. 215-216.

${ }^{51}$ Cf. M. Bakhtin, em Questões de literatura e de estética..., p. 403.

52 As publicações originais destes contos são: "Fantasticheria", em "Fanfulla della domenica", 24/ 8/ 1879; "L'Amante di Gramigna" (sob o título "L'Amante di Raja"), em "Rivista minima", fevereiro de 1880. 
conformam o método de criação do escritor verista. O conto ganha ares de manifesto da escola, quando se percebe que o seu principal objetivo não é propriamente narrar determinada história, mas sim discutir concepções e métodos literários inovadores, inspirados na práxis do Naturalismo francês, que são ilustrados com breves quadros narrativos, adaptados ao conteúdo temático próprio da realidade sociocultural italiana.

O autor-narrador apresenta o texto como uma carta em resposta a um pedido de uma signora da alta sociedade setentrional, com a qual vivera um romance fugaz e sedutor num cenário idílico à beira-mar de Aci Trezza, onde ela, depois de um primeiro momento de encanto e excitação, logo ficara entediada. Na prática, "Fantasticheria" é uma carta aberta ao leitor burguês, com a intenção de introduzir um espetáculo literário inédito, a representação realista de uma pequena comunidade da província siciliana. O narrador adverte o público de que o espetáculo pode lhe causar tanto estranheza quanto divertimento. O título do conto já desvela a ironia fina e o sofisticado tom da denúncia social que permeia toda a narrativa: para a burguesia, que passa a galope e vê superficialmente a vida vagarosa e simples da província, é fácil se dar ao luxo, por mero capricho ou excentricidade, de tomá-la por motivo de diversão intelectual. Como se o resultado da representação literária da existência "dessa gente sem eira nem beira" fosse pura fantasia e não correspondesse à realidade concreta de uma sociedade desfavorecida nos aspectos materiais, sociais e espirituais da existência.

Uma das propostas mais interessantes do conto é preparar os leitores para uma nova ótica literária que ajusta o foco em um novo objeto artístico: a realidade miserável da vida na província siciliana. O narrador convida a "gente di toga", que desfruta um mundo luxuoso, a olhar pelo microscópio o pequeno mundo da "gente di mare" de Aci Trezza ${ }^{53}$. Logo de saída, explicitando o caráter positivista da narrativa, ele se mune de princípios científicos para estabelecer um ponto de vista narrativo imparcial e objetivo, a partir do qual desenvolve a representação literária realista desta comunidade. A narrativa sustenta um sutil jogo de lentes entre a fantasia da burguesia e a realidade crua dos miseráveis.

${ }^{53}$ G. Verga, "Fantasticheria", em Tutte le novelle, cit., p 146 (as duas citações do período). 
A primeira não enxerga a segunda a olho nu, e esta, por sua vez, ofusca-se bestificada perante a miragem da opulência burguesa.

O narrador-observador focaliza uma célula da sociedade local, cujo núcleo é uma família de pescadores, e traz à tona as suas pequeninas causas. Ele expõe o nó do drama dos pequenos, como os chama, e propõe-se a desenvolvê-lo num romance a ser publicado futuramente. Ao descrever o lugar e sua população, que tem a pele mais dura que a casca do pão que come, o narrador debuxa o universo ficcional de Os Malavoglia (no qual Verga já trabalhava): o velho avô, timoneiro, que morre sozinho no hospital; a mocinha que espia por detrás do arbusto de manjericão; o pai e o filho marujos, vítimas fatais de naufrágios; a mulher que vende laranjas numa banquinha na rua; a mendiga que pede esmola na praça; aqueles que "comem o pão do rei" médico que chega montado num burrico; a casa onde falta a nespereira, já cortada; a taverneira, e a porta do seu estabelecimento abarrotada de gente em dia de chuva; os rochedos gigantescos que guardam o sofrimento e a carência desse povo. A análise da sociedade local não foge ao viés positivista, o narrador a compara com um exército de formigas: homens e insetos subjugados às mesmas e inexoráveis leis do instinto animal. A natureza reina soberana neste ambiente, onde os pequeninos nada podem fazer para refrear a sua fúria, que toma forma de borrascas, tempestades marítimas, ou ainda de pestes que periodicamente varrem o formigueiro humano.

"Non capisco come si possa vivere qui tutta la vita" ${ }^{55}$ é a questão que a distinta signora coloca, sem muito interesse por uma resposta, quando começa a sentir os primeiros sinais de tédio durante sua breve estada na aldeia. $O$ narrador a toma como mote e, a partir da premissa de que basta não dispor de cem mil liras para viver ali eternamente, desenvolve o "ideal da ostra" ${ }^{56}$ — uma alegoria filosófica de teor positivista e prognóstico pessimista, que se estabelece como estatuto da existência ficcional do elenco malavogliano e, de uma maneira geral, de toda a linhagem de personagens de obras veristas, principalmente as ambientadas nas províncias meridionais italianas. A teoria de Verga interpreta a malfadada vida da gente do mar, com base na idéia, já esboçada em "Nedda",

\footnotetext{
${ }^{54}$ Idem, p. 146.

${ }^{55}$ Idem.

${ }^{56}$ Idem, p. 151.
} 
de que o ambiente natural determina as condições da vida humana. O narrador faz uma recriação metafórica da gênese dos seres, ao supor que enquanto o destino semeava príncipes e duquesas aqui e ali, deixou cair esta pobre gente entre os rochedos. Numa atitude corajosa, eles se agarraram tenazmente aos escolhos, resignando-se a uma vida de privações e destinada à miséria, ignorância, desgraça e desesperança. O arrimo dessa comunidade é a "religião da família" 57 que invariavelmente, de pai para filho, reverencia o trabalho, a casa e as pedras que a circundam. Para o autor, o drama ganha dimensão literária quando a cobiça pelo bem-estar atinge qualquer um dos pequeninos corações, talvez o mais fraco ou incauto, a ponto de inspirar-lhe desejos que o projetam para além do seu círculo social e rompem com o restrito código moral da comunidade.

A temática, que em "Fantasticheria" é defendida como proposta "respeitabilíssima" 58 de estudo literário, torna-se o argumento central de Os Malavoglia. No prefácio ao romance, o autor volta a tratar o assunto de maneira mais detalhada, para explicar ao leitor o seu objeto artístico, sob a perspectiva de obra inaugural de um ciclo programado de cinco romances ${ }^{59}$. É a partir desse enfoque que as causas mesquinhas do reduzido mundo de Aci Trezza são concebidas como objeto de estudo literário, representante do "movente da atividade humana", da nascente da "cheia do progresso" nas dimensões "mais modestas e materiais" 60 . A investigação das pequenas causas retoma, sem dúvida, os estudos dos costumes como procedimento adequado para retratar de modo fidedigno a realidade social e decifrar o verdadeiro significado da dinâmica histórico-social contemporânea.

Quanto ao sistema lingüístico do conto, predomina a linguagem literária culta, permeada por um leve tom de informalidade, afinal de contas trata-se da representação da correspondência íntima entre interlocutores burgueses. $O$ narrador refere-se ao dialeto siciliano como semibárbaro e as poucas expressões locais que emprega no conto - "gente di mare", "gente di toga", "sotto le sue tegole", "occhiata di sole", "nei guai", "mangiano il pane del re" —

\footnotetext{
${ }^{57}$ Idem.

${ }^{58}$ Idem, p. 151.

59 Sobre o ciclo de romances programado por Verga, cf. pp. 21-2.

${ }^{60}$ Cf. G. Verga, "Prefácio", em Os Malavoglia, p. 7.
} 
figuram entre aspas, como a delimitarem dois planos de linguagem bem distintos: o alto e o baixo; aos quais correspondem duas realidades sóciogeográficas do país, radicalmente desiguais: lassù e laggiù. A organicidade lingüística do conto está de tal forma amarrada à realidade social da Itália pósunitária, que faz saltar aos olhos do leitor a fronteira invisível que, à revelia do processo de unificação política (e mesmo às custas dele), ainda divide a sociedade italiana em duas facções: a do norte, privilegiada, e a do sul, desfavorecida.

Verga não perde de vista as crises internas do seu país e as denuncia ao público com paciência didática. Ao botar o dedo nesta ferida nacional, prática timidamente inaugurada em "Nedda" e que pouco a pouco se torna mais incisiva nos contos de Vita dei campi e no romance Os Malavoglia, o escritor pretende não só sanar um quadro social desequilibrado, mas também educar o senso crítico dos leitores italianos, leia-se, a burguesia, que em matéria de literatura ainda preferia as amenidades e o melodrama ${ }^{61}$ à representação literária realista das questões sociais urgentes do país.

É interessante notar os cuidados, em doses homeopáticas, que Giovanni Verga ministra para legitimar um tratamento literário sério à problemática sociopolítica italiana e, ao mesmo tempo, cativar o espírito do público, experimentando progressivamente conceitos e procedimentos artísticos, que aos poucos abrem caminho para a prática literária naturalista na Itália e criam condições propícias à consolidação do Verismo. Verga comemora esta conquista com o amigo Capuana, numa carta que the escreve em março de 79. Ele avalia que todo o esforço feito até então tinha resultado num bom avanço, mas ainda deveriam "malhar muito o ferro" para que seus propósitos artísticos fossem bem compreendidos, e eles finalmente pudessem ser aplaudidos em vez de apedrejados ${ }^{62}$.

Em carta de abril de 1878, Verga anunciava seu grande projeto ao advogado e amigo Salvatore Paola Verdura. Ele pretendia, à maneira dos franceses, como Balzac em A Comédia Humana e Zola em Os RougonMarquart, compor um ciclo de cinco romances, intitulado Marea. O escritor relatava que a obra representaria a fisionomia da sociedade italiana moderna e

${ }^{61}$ Cf. G. Petronio, em L'attivitá letteraria in Italia, p. 710. 
traçaria a "fantasmagoria da luta pela vida"63, valendo-se dos métodos naturalistas da observação imparcial, minuciosa e da narração impessoal. Seu plano era produzir uma espécie de tratado antropológico da história social contemporânea de seu país, em que cada romance estudaria uma determinada classe social, desde a mais ínfima, onde a luta é "limitada ao pão cotidiano"64, como em "Padron 'Ntoni"; até a mais luxuosa, onde a cobiça e a avidez regem os propósitos humanos.

No prefácio a Os Malavoglia, Verga deu novo título ao ciclo, I vinti (Os vencidos), porém das cinco obras programadas, respectivamente I Malavoglia, Mastro Don Gesualdo, Duchessa di Leyra, L'onorevole Scipioni e L'uomo di lusso, somente as duas primeiras e parte da terceira foram concluídas. Mastro Don Gesualdo foi publicado em $1889^{65}$, e muito bem recebido pelo público e pela crítica. Tem-se notícia de que no verão de 1896, Verga trabalhava na redação da Duchessa di Leyra, e dois anos mais tarde, comunicou a Edouard Rod, com quem já tinha combinado a tradução da obra para o francês, que intensificara o ritmo do trabalho, porque já tinha tratado a sua publicação para o primeiro semestre do ano seguinte na "Nuova Antologia"66. Contudo, o romance nunca foi concluído, e o antigo projeto do ciclo viu-se abortado. De qualquer modo, esse projeto evidencia o interesse do escritor siciliano pelas questões críticas da realidade sociopolítica da Itália neste final de século; bem como, o seu firme propósito de denunciar os problemas sociais mais graves dela decorrentes.

Voltando ao prefácio, nele o romance é apresentado como um "estudo sincero e desapaixonado" das forças que movem a atividade humana, especialmente da luta pelas necessidades materiais nas "baixas esferas" termos utilizados pelo autor compõem uma espécie de máxima do escritor naturalista, que prima pela observação imparcial das forças subjacentes do

\footnotetext{
${ }^{62}$ Em Lettere a Luigi Capuana, p. 117.

${ }^{63}$ Apud C. G. Lanza, em "Invito alla lettura", cit., pp. 33-34.

${ }^{64}$ Idem, p. 34.

${ }^{65}$ Mastro don Gesualdo foi publicado originalmente em folhetins na "Nuova Antologia", de 01/ 7 a 16/ 12 de 1888; o texto foi revisado pelo autor e publicado em volume único em 1889, pelo editor Treves.

${ }^{66} \mathrm{Cf}$. E. Sanguineti, em "Cronologia della vita e delle opere", p. xxv.

${ }^{67}$ Em Os Malavoglia, p. 7.
} 
processo histórico contemporâneo ${ }^{68}$. Estes fatores definem a intenção programática do autor, e delineiam a "razão de ser sociológica"69 de Os Malavoglia, como a primeira obra de um ciclo de romances que pretende desenvolver um estudo que abarque toda a sociedade italiana.

A história de Os Malavoglia passa-se entre 1860 e o final da década de 70, no vilarejo de Aci Trezza, na região natal de Giovanni Verga. O período, que compreende os anos em que o escritor foi soldado e jornalista engajado, é considerado um dos mais conturbados e sangrentos da história da Unificação italiana; especialmente na Sicília, onde a "Guardia Nazionale" e o exército de Giuseppe Garibaldi, depois de derrotarem as últimas tropas da resistência bourbônica, combateram violentamente numerosos bandos de camponeses rebelados em decorrência da miséria e da fome que há muito grassavam o meridião. A luta se estendeu por cinco anos (1860-1865) e resultou num massacre de milhares de vítimas dos dois $\operatorname{lados}^{70}$. Tem-se notícia de que o batalhão de Giovanni Verga atuou em Nápoles numa cruel repressão a um levante de revoltosos, que culminou na execução sumária de sete líderes briganti $^{71}$ - como ficaram conhecidos os participantes desta rebelião popular, denominada Banditismo meridional ("Brigantaggio meridionale") ${ }^{72}$.

No prefácio ao romance, valendo-se de uma metáfora explícita dos ferozes conflitos internos, o autor define a obra como um relato objetivo da realidade social dos vencidos, que "levantam os braços desesperados, e dobram a cabeça sob o pé brutal dos que sobrevêm"73. Ele se apresenta como um observador levado pela mesma cheia, que se retira "um instante para fora do campo da luta para estudá-la sem paixão"74. Os Malavoglia não restituem episódios protagonizados por personagens célebres do passado, como ocorre nos primeiros romances do escritor e em tantos outros da tradição romântica européia. Trata-se da representação da realidade dos mais fracos e da

\footnotetext{
${ }^{68}$ Cf. E. Auerbach, em Mimesis, p. 430; e A. Hauser, em Historia social de la literatura y el arte III, p. 83.

${ }^{69} \mathrm{Cf}$. A. Candido, em Literatura e sociedade, p.46.

${ }^{70}$ Cf. A. Pagano, "1862 - Cronologia di un anno infame - La pulizia etnica piemontese nelle Due Sicilie", no sítio: www.cronologia.it.

${ }_{71}^{71}$ Cf. E. Sanguineti, em "Cronologia della vita e delle opere", p. xviii.

72 Cf. M. Lambertini, em "Brigantaggio meridionale", e "Il brigantaggio fu soltanto la guerra dei poveri", no sítio: www.cronologia.it.

${ }^{73} \mathrm{Em}$ Os Malavoglia, p. 9.

${ }^{74}$ Idem, p. 10.
} 
reconstituição de um acontecimento recente. A primeira edição do romance dista apenas duas décadas da fase mais violenta da Unificação italiana. O tema era atualíssimo e polêmico. O modo de tratá-lo também, pois seguia o receituário naturalista, segundo o qual "os caracteres, as atitudes e as relações das personagens atuantes devem estar estritamente ligados às circunstâncias da história da época” ${ }^{\text {75 }}$. Para tanto, as condições políticas e sociais do momento histórico contemporâneo são enredadas na trama narrativa, de modo a contribuir significativamente para a restituição fidedigna do "espetáculo", e alcançar, como Verga pretendia, a "representação da realidade como ela foi, ou como deveria ter sido"76.

Em suma, três fatores são fundamentais para introduzir a noção de historicidade em Os Malavoglia: a ambientação da trama no momento histórico presente, a adoção de um grupo social desfavorecido como objeto literário legítimo e o entrelaçamento do universo ficcional com elementos do mundo real. É a partir da organicidade funcional desses princípios no interior do romance que se instaura o ativismo da obra, uma vez que a assentam no tempo da atualidade real, de modo a estabelecer uma "zona de contato máximo"77, onde autor, objeto literário e leitor encontram-se num mesmo estrato axiológico e temporal. Para Bakhtin, essa conjunção favorece o desencadeamento de um processo de atuação da obra no espaço histórico em mutação:

A obra e o mundo nela representado penetram no mundo real enriquecendo-o, e o mundo real penetra na obra e no mundo representado, tanto no processo da sua criação como no processo subseqüente da vida, numa constante renovação da obra e numa percepção criativa dos ouvintes-leitores. ${ }^{78}$

Essa literatura de cunho sociológico, que investiga as causas das condições vigentes em determinada sociedade, reporta ao já referido método balzaquiano de "estudos dos costumes", como fonte de pesquisa e compreensão dos movimentos históricos que atuam no condicionamento da

\footnotetext{
${ }^{75}$ Cf. E. Auerbach, Mimesis, p. 408.

${ }^{76}$ G. Verga, "Prefácio", em Os Malavoglia, p. 10 (as duas citações do período).

${ }_{77}$ M. Bakhtin, em Questões de literatura e de estética..., p. 420.

${ }^{78}$ Idem, p. 358.
} 
vida humana na atualidade. Em Os Malavoglia, Giovanni Verga representa uma comunidade de pescadores isolada do mundo: narra detalhadamente sua vida diária, reproduz seu modo de falar e descreve com minúcias seus usos, costumes, ofícios, crenças e marcas culturais. Deste modo, são expostas as circunstâncias que compõem a vida da sociedade ficcional, e aos olhos do leitor, descortina-se um quadro humano muito significativo, que inevitavelmente remete às verdadeiras condições sociais, políticas e econômicas que determinam a vida da população insular siciliana.

O contexto sociopolítico real da Sicília pós-unitária deixa-se entrever na narração de certos episódios, como a revolta dos aldeões contra o imposto sobre o piche, além daquele já cobrado sobre o sal, dois produtos essenciais numa comunidade de pescadores; o alistamento obrigatório no serviço militar de dois irmãos Malavoglia, cuja partida da terra natal debilita a força de trabalho do núcleo familiar; a morte de um deles durante uma batalha naval ocorrida em 1866, em que uma esquadra austríaca destruiu o encouraçado "Rei da Itália"; a chegada à aldeia da epidemia de cólera que mata a mãe da família, e que de fato se alastrou pela região em 1867; a tentativa fracassada do filho mais velho de ganhar dinheiro na cidade grande, e o seu retorno em condições miseráveis; a incompetência administrativa do prefeito e do secretário da província, que em vez de defenderem interesses da população, favorecem causas próprias. Ademais, no decorrer da história, algumas personagens aludem ocasionalmente a personalidades centrais do cenário político da época: os Bourbons, linhagem familiar soberana do antigo reino das Duas Sicílias; Franceschello, apelido depreciativo atribuído ao rei Francesco II, deposto em 1860 e exilado em Roma; Garibaldi, estrategista militar que em nome da Unificação italiana derrotou as tropas de Francesco II e desintegrou o Banditismo; Vittorio Emanuele II, soberano da casa Sabóia e rei da Itália pós-unitária. A partir da identificação na narrativa de elementos reais do cenário sócio-político-econômico do país, estabelecem-se pontos de contato entre o enredo romanesco e o processo histórico real. À medida que a leitura do romance desvela as condições de miséria e desamparo a que a sociedade ficcional está fadada, oferece também subsídios para a compreensão da situação concreta e verdadeira da população siciliana à época - devastada pelo jogo abusivo dos poderosos, subjugada 
pelo despotismo, oprimida pelas injustiças sociais, castigada pela pobreza, sujeita a pragas sanitárias, vitimada por desgraças familiares, e carente de perspectiva existencial.

Os Malavoglia fazem um recorte antropológico da sociedade das províncias sicilianas no ápice da Unificação Italiana; e a versão oficial deste processo histórico, registrada em documentos governamentais, ilustrada em livros didáticos e admitida em aulas de história durante várias décadas no país ${ }^{79}$, diferia muito da realidade representada no romance. Isso se deve especialmente ao fato de o narrador-observador adotar o ponto de vista da classe subjugada. Conforme o autor explica no prefácio, o enfoque particularizado evidencia aspectos pouco nobres do "espetáculo" ${ }^{80}$, como a irrequietude, a ganância, o egoísmo, os vícios e as fraquezas que o movem. Tal perspectiva opõe-se radicalmente à visão generalizada do conjunto, que tende a diluir os pormenores pouco convenientes e a representar tão-somente a grandiosidade do todo, como sói acontecer em relatos tradicionais de História, ou mesmo em romances históricos convencionais. O aspecto documental da narrativa literária propõe ao leitor, de qualquer época ou país, uma leitura amarrada à realidade histórica, que o leva a se enxergar como peça integrante do mesmo quadro da civilização humana. Neste sentido, a função artísticosocial do romance verista satisfaz a tenção educativa que a inspira. No plano sociocultural, Os Malavoglia podem ser interpretados como uma contraversão da história oficial da Sicília pós-unitária, justamente por contá-la da perspectiva dos vencidos; e no plano artístico, como um novo paradigma literário, pois a adoção de um novo objeto artístico, aliada a um enfoque narrativo original propõe uma série de procedimentos inovadores ao rígido quadro da literatura italiana oitocentista.

A noção de objeto artístico como objeto de estudo literário está relacionada com a função que a literatura criou para si dentro da cultura burguesa européia do século XIX, especialmente na escola naturalista, em que predomina o cientificismo e a intenção didático-documental da realidade social contemporânea. Esse tipo de expressão literária privilegia o fator social no

\footnotetext{
${ }^{79}$ Cf. C. Coppola "L'insabbiamento culturale della questione meridionale - controstoria dell'unità d'Italia" no sítio: www.cronologia.it.

${ }^{80}$ G. Verga, "Prefácio", em Os Malavoglia, p. 10.
} 
processo de criação, de modo que o vocabulário do universo representado recebe tratamento estilístico cuidadoso na composição do sistema lingüístico da obra. Para Auerbach, a inserção da língua vulgar na narrativa literária foi fundamental para tratar com seriedade o cotidiano real das pessoas sem importância ${ }^{81}$. Os estudos de Bakhtin concordam com tal proposição, ao sustentar que a realidade da vida atual não é admitida como objeto de representação para nenhum gênero elevado; e o tratamento literário sério aplicado à vida do homem comum só se dá a partir do rebaixamento da língua literária culta e da mistura dos níveis de linguagem ${ }^{82}$. Numa síntese da tese do filólogo russo, pode-se afirmar que é a dialogicidade interna das linguagens estratificadas do discurso romanesco que revela o contexto social concreto.

Tudo indica que desde a primeira idéia que inspirou o romance Os Malavoglia, Verga tinha em mente a preocupação de elaborar uma solução lingüística que fizesse jus à proposta de representação realista do objeto. Em carta de setembro de 1875, ele comunicava ao seu editor Emilio Treves que estava trabalhando num "esboço marinheiresco" intitulado "Padron 'Ntoni" (texto que deu origem ao romance) $)^{83}$. É bem provável que, conforme o escritor relatou ao jornal "Tribuna" em 1911, a origem deste esboço remonte a um "acaso verídico" que the ocorrera ${ }^{84}$. Segundo a entrevista, Verga conta que certa vez caiu-Ihe em mãos um jornal de bordo que narrava as peripécias de um capitão em seu veleiro, e muito o intrigou, principalmente pela concisão e total falta de cuidados gramaticais do texto. "Golpeou-me, reli-o: era o que eu procurava sem distintamente me dar conta. Às vezes, sabe-se, basta um ponto. Foi um facho de luz" ${ }^{15}$.

O fato de a primeira pedra do romance ser um material de caráter nãoliterário, de cunho regionalista, e escrito num registro lingüístico específico da lida marinheira, demonstra que Verga estava motivado pela orientação de extrair a ficção da vida real, tinha sua atenção voltada a determinado grupo ou

\footnotetext{
${ }^{81}$ Em Mimesis, p. 26.

${ }^{82}$ Em Questões de literatura e de estética..., p. 409.

${ }^{83}$ Apud C. Simioni, em "Introduzione", p.13. Segundo C. Riccardi (Tutte le novelle, p. iv), Verga começou a trabalhar no esboço de Padron 'Ntoni no outono de 1874.

${ }^{84} \mathrm{Cf}$. E. Sanguineti, em "Cronologia della vita e delle opere", p. xxvi.

${ }^{85}$ Apud C. Simioni, em "Introduzione", p.14.
} 
problemática geográfico-social (no caso, da sua região natal), e preocupava-se com a questão da língua literária.

Dessa perspectiva, há que se considerar ainda, outro traço essencial da narrativa do romance, que advém do interesse do autor pela tradição narrativa popular, despertado por uma "pequena obra-prima" de Capuana, o divertido conto "Lu cumpari", que retoma o mote de uma velha canção folclórica ${ }^{86} . \mathrm{Em}$ carta de 1882, Verga confessava ao amigo, que devia a ele a "primeira inspiração da forma genuinamente popular"87 que tinha procurado dar a suas novelas. Enquanto escrevia o romance, Verga trocava idéias sobre o seu trabalho com Capuana; ora pedia sugestões de ditos espirituosos ou injúrias da tradição oral, ora indicações de antologias e dicionários de provérbios e modosde-falar do dialeto siciliano ${ }^{88}$.

Havia algum tempo, Capuana dedicava-se à pesquisa, tanto de clássicos da literatura italiana, quanto de narrações populares e provérbios sicilianos, a fim de coletar material e definir as perspectivas ideológico-verbais de uma língua literária que representasse com autenticidade o mundo popular das províncias meridionais, e fosse compreendida pelo público leitor concentrado nas regiões privilegiadas do país. "Ah, a língua!... O nosso gravíssimo escolho!" ${ }^{29}$, desabafaria Capuana ao relembrar o trabalho que teve, durante a redação de Giacinta, para chegar a uma solução estilística eficaz.

Verga planejava passar algumas semanas em Aci Trezza, logo que terminasse de escrever o romance, para dar 0 tom local à narrativa ${ }^{90}$. Entretanto, em razão da doença e subseqüente morte da mãe do escritor, ele viajou às pressas para a Catânia, em 1878 e só retornou para Milão no ano seguinte. De lá escreveu a Capuana, contando que, apesar de estar muito abalado, procurou afastar a tristeza, aproveitando a estada à beira mar para observar de perto "aqueles pescadores e colhê-los vivos como Deus os fez"1.

\footnotetext{
${ }^{86}$ Cf. G. Verga, em Lettere a Luigi Capuana, p. 201.

${ }^{87}$ Idem, p. 200.

${ }^{88}$ Idem, p. 93 (carta de 17/ 5/ 1878); p. 121 (10/ 4/ 1879).

${ }^{89}$ Apud G. Petronio, em L'attivitá letteraria in Italia, p. 716. O termo utilizado por Capuana, "scoglio", foi aqui traduzido literalmente, para manter a referência indireta que o escritor faz aos escolhos, ou 'farilhões dos Ciclopes', situados em Aci Trezza, que, na literatura verguiana são simbolicamente associados à força retrógrada, limitação, desgraça, perigo (cf. p.19, "o ideal da ostra").

${ }^{90}$ Cf. G. Verga, Lettere a Luigi Capuana, p. 93 (carta de 17/ 5/ 1878).

${ }^{91}$ Idem, p. 114 (carta de 14/ 3/ 1879).
} 
Ao incorporar no processo de criação do romance as linguagens de outros gêneros textuais e da tradição oral - o diário de bordo, os contos popularescos, o linguajar dos marujos, o modo-de-falar da população de Trezza, os rifões da sabedoria popular siciliana - o autor implanta na sua gênese o plurilingüismo $^{92}$, que ressoa em todos os seus elementos formais e conteudísticos. A organização do diálogo interno das diversas linguagens sociais relativas às áreas de atuação e aos sistemas ideológico-culturais da comunidade lingüística representada define a "estilística sociológica" ${ }^{\text {"93 }}$ do romance. Segundo Bakhtin, o princípio ativo do plurilingüismo social propõe a ruptura do absolutismo da língua literária, graças a essa dispersão da consciência do romancista, que se estende a campos culturais ainda não explorados, promovendo a "descentralização semântico-verbal do mundo ideológico" ${ }^{94}$. Trata-se de uma revolução muito importante nos domínios da literatura, porque liberta a expressão artística do poder arbitrário de uma língua literária única.

Uma batalha particularmente difícil no campo da literatura italiana do século XIX, onde o romance era considerado um gênero secundário, e predominava uma língua literária conservadora, totalmente refratária ao coloquialismo e aos dialetos regionais. As primeiras manifestações contrárias à regra clássica do nível lingüístico culto e do estilo elevado ocorrem no Romantismo, em razão de suas tendências individualizantes e historicistas, que tomam personagens das mais diversas classes sociais como objeto de representação. Na década de 1820, Alessandro Manzoni, com seu romance Os noivos, já tinha preparado boa parte do terreno, simplificando os excessos retóricos e o preciosismo habitual da língua literária, para contar a história de Renzo e Lucia, gente simples da província. Contudo, a proposta naturalista requeria ousadia maior, porque perseguia o ideal da impessoalidade narrativa, cujo propósito era deixar as personagens populares falarem por si, sem o intermédio de um narrador que elevasse o discurso ao nível do autor burguês. Os escritores veristas relegaram a tradição da língua literária culta para representarem os dialetos regionais com propriedade; no entanto, a significação

\footnotetext{
${ }^{92}$ Cf. M. Bakhtin, em Questões de literatura e de estética...,pp. 107-133.

${ }^{93}$ Idem, p. 106.

${ }^{94}$ Idem, p. 164.
} 
dessa atitude artística não foi compreendida pela maior parte dos leitores e da crítica da época, a qual, durante um bom tempo, atribuiu-lhes a fama de maus escritores $^{95}$.

A língua literária que Giovanni Verga criou em Os Malavoglia resultou no "instrumento mais perfeito e eficaz que o estilo narrativo conheceu na Itália por meio século"96, resume Antônio Cândido, expressando uma opinião que se afina com a da crítica italiana atual. No prefácio ao romance, o autor explicita os critérios que orientam a sua criação lingüística. Primeiramente há que se considerar o desejo sincero de "demonstrar a verdade", e então, para que o quadro social explorado possa ser representado de modo realista, é essencial imprimir no discurso narrativo a marca genuína da língua falada da comunidade social retratada. Deve-se levar em conta o fato de que "a linguagem tende a individualizar-se, a enriquecer-se de todas as meias tintas, dos meios sentimentos, de todos os artifícios da palavra para dar relevo à idéia". Para que a reprodução artística seja exata, prossegue o autor, é preciso "seguir escrupulosamente as normas desta análise", pois, no seu entender, "a forma é tão inerente ao sujeito, quanto cada parte do próprio sujeito é necessária à explicação do argumento geral" ${ }^{97}$. O discurso narrativo do romance é construído de acordo com o vocabulário e a sintaxe da língua falada dos moradores da aldeia siciliana. A solução estilística de Verga combina a língua culta com a rústica, e o seu narrador trabalha com quatro possibilidades lingüísticas: "toscano culto, toscano popular; siciliano eventualmente submetido a tratamento literário, siciliano popular"98. O ritmo da oralidade e o lugar-comum típicos do dialeto local evidenciam-se, na narrativa, pela reprodução de provérbios, expressões idiomáticas, frases feitas, jargões do trabalho e da lida doméstica; bem como, pela criação e uso recorrente de epítetos, formulados com elementos do senso comum da comunidade retratada.

A língua do romance é articulada através de um narrador em terceira pessoa que continuamente rompe as formas fixas da enunciação ${ }^{99}$, suprimindo as convenções sintáticas dos discursos direto, indireto e indireto livre, e

\footnotetext{
${ }^{95}$ Cf. N. Merola, em Giovanni Verga, p. 14.

${ }^{96} \mathrm{Em}$ "O mundo-provérbio", cit., p. 348.

${ }^{97}$ G. Verga, em "Prefácio", p. 8.

98 Cf. A. Candido, em "O mundo-provérbio", p. 348.

${ }^{99}$ Cf. M. Bakhtin, Marxismo e filosofia da linguagem, pp. 139-143.
} 
nivelando as vozes do narrador e das personagens num só plano discursivo. Em carta a Edouard Rod, tradutor de Os Malavoglia para o francês, Verga mostrava-se plenamente ciente de que a língua literária que criara era inédita na literatura italiana, e enfatizava que sua intenção fora exprimir com nitidez a língua local, preservando-Ihe ao máximo o tom verdadeiro e a marca própria ${ }^{100}$. De fato, é a força da expressão social da língua do romance que o configura como uma consciência lingüística ativa e participante do processo de evolução da língua literária italiana ${ }^{101}$. No plano estrutural da narrativa, a língua é peçachave que faz convergir os recursos estilísticos empregados pelo autor para a construção do narrador impessoal, e de uma verossimilhança narrativa perfeitamente orgânica. O estudo analítico, desenvolvido no segundo capítulo deste trabalho, pretende investigar como tais processos ocorrem no interior da obra, para que se possa refletir sobre as suas funções artístico-sociais.

Por ora, interessa registrar que os ideais naturalistas, relativos a um narrador e uma língua literária que deixam o objeto falar por si, vêem-se plenamente contemplados no romance de Verga. De acordo com Roman Jakobson, toda inovação artística que se propõe a uma maior aproximação da realidade deforma ao máximo os cânones artísticos ${ }^{102}$; e a partir dessa perspectiva, pode-se considerar que Os Malavoglia, ao desenvolverem uma série de procedimentos e recursos artísticos inovadores, contribuíram para a deflagração de uma grande crise do gênero no âmbito da literatura italiana. A língua malavogliana, como instrumento de representação realista da sociedade da província siciliana, promove uma revolução que está intimamente ligada ao processo de Unificação. Ela integra língua literária convencional e língua dialetal, e neste gesto simbólico, propõe o reconhecimento e a legitimação das diversas identidades culturais das regiões italianas. Ao organizar diferentes vozes sociais de uma só nação, a língua do romance ganha dimensão política, e define a sua função artístico-social. O romance-tese propõe a unificação da literatura italiana, pois, ao conferir dignidade literária à língua, temas, motivos e personagens da Sicília, violenta a hegemonia artística setentrional.

\footnotetext{
100 Cf. A. Candido, em "O mundo-provérbio", p. 349.

101 Cf. M. Bakhtin, em Questões de literatura e de estética..., pp. 164-210.

102 Cf. R. Jakobson, "Do Realismo Artístico", em Teoria da Literatura..., cit., pp. 122-123.
} 
Em "L’Amante di Gramigna", outra faceta da crise social da Itália pósunitária é exposta. O conto é mais uma peça importante da construção do Verismo e do narrador impessoal; bem como um dos textos mais relevantes de Verga sobre as próprias convicções e intenções artísticas. Divide-se em duas partes: a primeira é uma introdução dedicada ao escritor Salvatore Farina, em que o autor discute o critério da verdade psicológica como argumento principal de uma nova literatura, e aborda a problemática da impessoalidade no romance moderno; a segunda é a história de Peppa e seu amante, o brigante Gramigna.

$\mathrm{Na}$ introdução, o autor explica que se trata de uma narração popular de valor histórico, um "documento humano"103, que ele reproduz tal e qual ouviu há pouco nas ruas. "Parecchi anni or sono, laggiù lungo il Simeto, davano la caccia a un brigante, certo Gramigna"104. O início do conto situa a história em pleno desenrolar do Banditismo meridional, e retrata a caçada a um líder brigante. Gramigna, perseguido sem trégua por toda a força policial e militar da região, é o mais resistente deles. Suas proezas e insubordinação extraordinárias geram lendas que correm toda a província e inspiram à população sentimentos contraditórios de admiração e medo. A aura lendária de Gramigna eleva-o à condição de herói popular e seduz a bela Peppa, que está de casamento marcado com um dos melhores partidos do lugar, o compadre Finu. Fascinada pela lenda, a moça abandona a mãe, o noivo e o rico enxoval para juntar-se ao bandido, que nem conhece pessoalmente. Quando Peppa se desgarra do seio da comunidade, rompe com a "religião da família"; e a partir de então tem início toda uma sorte de desgraças que se abatem sobre ela e os seus. Junto a Gramigna, a jovem leva uma vida degradante; e depois de muitas lutas sangrentas e fugas arriscadas, finalmente os dois são capturados. A mãe de Peppa vende tudo o que tem para pagar o advogado e tirá-la da prisão. Ela volta à casa materna com um filho de Gramigna nos braços, e lá permanece, como uma fera enjaulada, até que sua mãe morre de desgosto. Na calada da noite, Peppa abandona a criança à roda dos expostos e vai para a cidade onde, dizem, Gramigna está preso. Pouco tempo depois, fica sabendo que o amante foi transferido para uma cidade muito distante, além do mar; e só lhe resta então "ganhar o pão" por ali mesmo, prestando serviços aos soldados da caserna.

${ }^{103}$ Em "L'Amante di Gramigna", cit., p. 203. 
O conto retrata as condições de vida da comunidade, sob as circunstâncias vigentes do presente histórico; e o narrador vale-se dos reflexos de tal situação no imaginário popular para contar a história. Como se trata da estilização paródica de uma lenda popular, Verga sincroniza dois planos narrativos e dois tipos de narrador: um conto escrito pelo autor burguês para o leitor burguês, que reproduz uma lenda contada por um narrador popular para as pessoas do povo. No ponto em que ocorre a defasagem desses planos, em que cada um inevitavelmente se resguarda à sua própria natureza, tornam-se evidentes os diferentes modos de transmissão de conhecimento e experiência narrativa de um e de outro. De um lado, o escritor burguês experimenta uma técnica narrativa e conceitos artísticos inusitados, com o propósito de educar a burguesia para uma literatura e uma consciência social novas; de outro, o narrador naturalista estiliza o narrador popular, que conta uma parábola anônima e transmite um preceito moral, cuja finalidade é perpetuar a tradição, educando a comunidade local para a preservação de sua cultura e seus valores.

A lenda é um gênero narrativo composto de elementos que povoam o imaginário popular, e, neste sentido, a história de Peppa e Gramigna expressa simbolicamente medos e temores que assombram a província siciliana no período pós-unitário: miséria, fome, abandono, prostituição, desagregação familiar, desamparo social e carência de perspectiva existencial. Desta feita, Verga expõe camadas mais profundas e sutis da ferida social da Itália recémunificada, haja vista a declaração que faz na introdução do conto, afirmando que seu interesse maior concentra-se no estudo e na representação literária séria dos fenômenos psicológicos da sociedade.

Há que se observar ainda outro procedimento artístico, experimentado nesse conto e desenvolvido de forma mais sistemática e produtiva no romance, que atua no âmbito das verdades interiores, com a intenção de questionar e desconstruir valores impostos aos indivíduos pela tradição religiosa. Trata-se da enformação de personagens centrais da trama, a partir da paródia de legendas de santos e mártires da fase inicial do Cristianismo, os quais são patronos da região em que a história se passa, e protetores de profissões, atividades ou

${ }^{104}$ Idem, p. 204. 
costumes típicos do lugar. Peppa, por exemplo, é comparada à padroeira das prostitutas arrependidas ${ }^{105}$, "lei che ci aveva dell'oro quanto Santa Margherita!"106 . Nesse processo de representação paródica, a trajetória da vida, as provações e o destino que o enredo reserva à personagem correspondem, até certo ponto, àqueles que a legenda da santa narra. Ao parodiar hagiografias o autor reporta para o seu texto certas características marcantes do gênero, e as organiza na estrutura narrativa em prol da despersonalização do narrador e intensificação da verossimilhança do fato narrado. A "forma hagiográfica é tradicionalmente convencional" ${ }^{107}$, pois parte do princípio de que seu objeto de representação é pouco verossímil, e para que sua narrativa inspire credibilidade, requer uma espécie de renúncia resignada do autor. Essa atitude de resignação para lidar com a inadequabilidade de tal objeto, propõe a elaboração de uma voz narrativa que abre mão da individualidade autoral para ressoar numa determinada freqüência comum, de generalização. De acordo com essa perspectiva, o narrador verista ao mesmo tempo em que intensifica a marca de impessoalidade no seu discurso, desfruta da "autoridade indiscutível" ${ }^{108}$ que advém da narrativa hagiográfica, para adentrar o imaginário do leitor, sem que este imponha restrições. No que diz respeito à representação realista dos fenômenos psicológicos pretendida por Verga, esse recurso cai como uma luva, pois retrata a mentalidade ultrapassada e as limitações imutáveis da vida deste grupo social, por meio da paródia de seus próprios ícones e valores religiosos.

As linhas que Giovanni Verga dedica a Farina têm, como "Fantasticheria", um quê de manifesto verista, porque, além de apresentarem as concepções e intenções programáticas do escritor, são redigidas na primeira pessoa do plural, sugerindo que ele é porta-voz das idéias de um grupo que atua no desenvolvimento de uma nova literatura. "Noi rifacciamo il processo artistico al quale dobbiamo tanti monumenti gloriosi” ${ }^{109}$ - seu discurso não rejeita a tradição romântica, antes, digere-a e dá continuidade à exploração de um argumento que seus antigos representantes já tinham intuído, "o fato humano",

${ }^{105}$ Cf. www.santiebeati.it.

${ }^{106}$ G. Verga, em "L'Amante di Gramigna", p. 208.

107 Cf. M. Bakhtin, em Estética da criação verbal, p. 170.

${ }^{108}$ Idem.

${ }^{109}$ Em “L’Amante di Gramigna", p 203. 
marcado pelas "lágrimas verdadeiras, febres e sensações que passaram pela carne" ${ }^{, 110}$.

A expressão que usa para definir a arte do futuro, "ciência do coração humano"111, traduz o momento de transição na literatura, quando uma nova geração de escritores, provida de conviç̧ões e ideais artísticos que articulam um estilo inovador, reelabora um velho conteúdo humano, adaptando-o a uma nova forma de expressão literária. Esse novo estilo distingue-se por aplicar, como Verga explica, os princípios científicos da objetividade e da causalidade no estudo do "homem interior"112, com o escopo de demonstrar o "desenvolvimento lógico"113, e desvendar os fenômenos psicológicos, que, no seu entender, constituem a principal e inesgotável fonte de argumentos do romance moderno ${ }^{114}$. O preceito está estritamente ligado ao positivismo de Comte, que propõe a ordenação das ciências exatas e naturais como modelo de análise, interpretação e transmissão do conhecimento humano.

As palavras do autor traduzem a típica visão de mundo do "eu naturalista" que procura equilibrar razão e emoção num só corpus fisiológico, composto com base nas descobertas científicas, que constituem a tônica da época. No âmbito da literatura italiana, Verga introduz a discussão sobre a aplicabilidade em literatura de princípios da psicologia - disciplina que, somente a partir de 1860 e em alguns países da Europa, como França e Alemanha, passou a ser colocada como ciência experimental. Ao argumentar que o verdadeiro "fato humano" é de natureza psicológica, Verga demonstra que os critérios que orientam seu método de criação não se restringem à compreensão de uma representação realista apegada tão-somente à realidade concreta, que, conforme coloca Adorno, apenas "reproduz a fachada" e "auxilia na produção do engodo"115; mas sim, privilegiam a representação que explora a essência psicológica dos indivíduos. A partir dessa perspectiva, pode-se considerar que, na concepção do escritor, se o fato verdadeiro é o psicológico, a consciência do artista que o representa não é menos verdadeira; e a subjetividade do autor

\footnotetext{
${ }^{110}$ Idem.

${ }^{111}$ Idem, p. 204.

112 Idem.

${ }^{113}$ Idem, p 203.

${ }^{114}$ Idem.

${ }^{115}$ Em Notas de literatura I, cit., p. 57.
} 
traduz-se em objetividade, dado que a percepção psicológica e a concepção artística da realidade atuam num mesmo plano de representação. A realidade do existir e aquela representada artisticamente são uma só.

$\mathrm{Na}$ teoria e na prática, como nos mais bem-sucedidos contos de Vita dei campi e no romance Os Malavoglia, Verga propõe a observação dos caracteres das personagens e dos valores morais atuantes em cada situação, por meio de um processo dedutivo, em que a inferência do leitor faz-se essencial para que o ambiente e as condições exteriores que condicionam o universo ficcional sejam depreendidos. De acordo com esse método, os fenômenos psicológicos são veiculados na narrativa a partir da consciência do autor, que se dá conta e se apropria das forças subjacentes atuantes no momento e no lugar em que a história se passa. O autor então as decifra sistematicamente ao conceber o estado e os processos mentais e emotivos de cada uma de suas personagens, e expressá-los através do discurso de seu narrador. Este, por sua vez, descreve as personagens em situações corriqueiras e de interação entre si, de modo que as qualidades e os valores internos individuais revelam-se naturalmente e atuam de per si na representação da realidade social e material a que estão submetidas. Esse método de criação privilegia a representação da fisiologia do espírito humano, de forma integrada a um contexto de amplitude antropológica.

Ao tratar a questão da impessoalidade no romance moderno, em "L’Amante di Gramigna", Verga ousa ir além da proposta lançada em "Fantasticheria", onde convida o leitor a observar o objeto artístico por intermédio do microscópio. Em "L'Amante di Gramigna", tais distâncias protocolares são abolidas, pois sua intenção declarada é deixar que o leitor se depare com "o fato nu e genuíno"116, não submetido à lente do escritor; em tese, não há mais qualquer barreira que separe o leitor-observador do objeto de representação.

$\mathrm{Na}$ resenha que fez a Os Malavoglia, Capuana alega que a questão da impessoalidade narrativa é o alvo supremo das ambições dos romancistas da época. A razão histórica deste ideal artístico da escola naturalista decorre de um processo extenso e gradativo de tomada de consciência da realidade, surgido do mal-estar social e da sensação de inadequação do indivíduo ao

${ }^{116}$ Em “L'Amante di Gramigna", p 203. 
mundo pós-napoleônico ${ }^{117}$. O Naturalismo, nascido sob o signo da desilusão, caracteriza-se como arte de oposição, engajamento social e impessoalidade ${ }^{118}$; e adere à revolução do pensamento que as doutrinas positivista, evolucionista e mecanicista impõem a partir da segunda metade do século XIX. Os escritores naturalistas reformulam os critérios da criação literária, desenvolvendo uma expressão artística extremamente objetiva, de cunho determinista e apegada aos fatos reais. Move-os a conviç̧ão de que a impessoalidade e a insensibilidade são os únicos critérios capazes de garantir a representação literária realista da realidade, e dar procedimento à compreensão exata das causas dos fenômenos sociais e das condições de vida da atualidade. Além do mais, esta é uma época em que se multiplicam as descobertas científicas e as invenções tecnológicas, as quais, por sua vez, aceleram o ritmo do cotidiano e promovem transformações profundas no modo de vida. A narração literária tradicional parece não acompanhar o compasso dessas mudanças; e o escritor naturalista vê-se compelido a criar uma nova instância narrativa que seja capaz de representar, com propriedade e isenção, esse mundo em mutação.

Numa carta que escreveu a Capuana em fevereiro de 1881, mês do lançamento de Os Malavoglia, Verga se referia à sua "velha fixação"119 pela impessoalidade da obra de arte. Na sua opinião, a obra bem-sucedida configura-se como um organismo vivo, completo, imortal; e, portanto, muito mais valiosa do que o artista que a criou. Para defender a sua idéia junto ao amigo, que, conforme o próprio Verga relatava na carta, tendia a considerar a obra em suas relações com a mente que a produziu, colocava as seguintes questões: "Che cosa è non il tuo nome, né il mio, ma quel del Manzoni, o di Zola, in faccia ai Promessi Sposi e dell'Assomoir? L'opera d'arte non val più dell'autore?"120 Verga sabia que Capuana não acolhia integralmente as suas concepções, mas fez questão de prenunciar que a arte do futuro deveria, de maneira universal, admitir o total desapego pelo artista.

Tais declarações denotam que o escritor reflete sobre a trajetória de evolução do romance moderno e participa ativamente de tendências e idéias

${ }^{117}$ Cf. E. Auerbach, em Mimesis, p. 411.

${ }_{118}$ Cf. A. Hauser, em Historia social de la literatura y el arte III, p 83.

${ }_{119}^{119}$ Apud R. Scrivano, em La narrativa di Giovanni Verga, cit., p. 137 (carta de 19/2/ 1881).

${ }^{120}$ Idem. 
artísticas originais em seu tempo. A Salvatore Farina, Verga afirma que o triunfo do romance será alcançado quando a organicidade de suas partes for tão perfeita, e a sua matéria, tão necessária, que a "mão do artista" permanecerá totalmente invisível, de modo que a obra tenha "a marca do acontecimento real" e pareça "ter sido feita por si", como um "fato natural", que espontaneamente amadurece e nasce sem conservar nenhum ponto de contato com o autorcriador, e nenhuma mancha do "pecado original"

Essa previsão, assim como os termos que usa para expressá-la, remetem, não por acaso, ao cânone da impessoalidade artística concebido por Flaubert ${ }^{122}$; especialmente porque as duas noções trazem fortes resquícios românticos, que as fazem vibrar numa tônica "místico-realista"123. De acordo com Auerbach, a correspondência do escritor francês, especialmente entre os anos de 1852 a 1854, quando trabalhava em Madame Bovary, é uma fonte rica de suas concepções e intenções artísticas ${ }^{124}$. Numa delas, de dezembro de 1852, endereçada a Louise Colet, o autor escreveu: "L'auteur, dans son ouvre, doit être comme Dieu dans l'univers, présent partout, et visible nulle part" ${ }^{125}$. O escritor italiano comunga a teoria de Flaubert sobre o artista que imita os processos da Criação, para que a sua obra se constitua como um organismo vivo, de existência real e autônoma; e a representação do objeto se faça de per si, pelo simples fato natural de que é como deve ser.

Em literatura, o ideal da impessoalidade recai sobre o narrador: os esforços do autor convergem para não se deixar entrever o narrador na matéria narrada. A "emancipação do romance em relação ao objeto"126 é limitada justamente pela linguagem discursiva, a qual, por sua vez, é o único instrumento de que o narrador dispõe para contar a história. Superar tal limitação depende, em boa medida, da força criativa da técnica de representação desenvolvida no discurso do narrador para iludir o leitor de que a voz narrativa é o próprio objeto. Uma representação artística funciona bem, quando "não é entendida como representação, mas como o próprio objeto

\footnotetext{
${ }^{121}$ G. Verga, em "L'Amante di Gramigna", p 204 (todas as citações do parágrafo).

122 Cf. V. Masiello, "La lingua di Verga tra mimesi dialettale e realismo critico", em A. Rosa [et alii], Il caso Verga, cit., p. 94.

${ }_{123}$ Cf. E. Auerbach, em Mimesis, p. 436.

${ }^{124}$ Idem, pp. 435-436.

${ }^{125}$ Apud V. Masiello, em "La lingua di Verga tra mimesi dialettale e realismo critico", p. 94.
} 
representado"127. Dessa perspectiva, compreende-se como a construção bemsucedida do narrador verista, que não se deixa detectar com facilidade na narrativa, está intimamente vinculada à aplicação maciça do princípio de verossimilhança ao sistema lingüístico-discursivo do romance. $O$ objeto de representação artística parecerá autêntico ao leitor, na mesma medida em que a voz narrativa também soar natural e legítima, por se expressar numa linguagem identificada com o universo sócio-cultural representado.

Verga trabalhou nos contos de Vita dei campi e no romance Os Malavoglia sempre com o firme propósito de alcançar a impessoalidade narrativa, a sua "velha fixação". E, de fato, se for observada a seqüência cronológica dessas obras ${ }^{128}$, os contos podem ser tomados como etapas experimentais da composição do narrador impessoal, almejado pelo autor, e alcançado no romance de maneira inigualável, como avaliou Capuana, na já referida resenha. Em "L'Amante di Gramigna", ao propor a reprodução fiel de uma narração popular de caráter histórico, Verga lança os fundamentos da construção do seu narrador. Ele informa que apenas repetirá a história que ouviu, preservando-Ihe as palavras "simples e pitorescas"129. Ou seja, propõe a recuperação escrita de uma narrativa da tradição oral popular. A escolha desse tipo de material e dessa maneira de narrar é decorrente das convicções e intenções artísticas do escritor, que o deixam de prontidão para pesquisar aquilo que chama de "documento humano"130, o qual pretende reproduzir em seu texto, sem o intermédio de um narrador, deixando o objeto falar por si.

$\mathrm{O}$ autor colhe o argumento literário da realidade imediata, extraindo material artístico vivo da tradição oral popular. Segundo Benjamin, "a experiência que anda de boca em boca"131 é a fonte de todos os narradores, e ao recorrer diretamente a ela, Verga investe na despersonalização do seu narrador, valendo-se do princípio de que a história escrita que provém da tradição oral popular tende a preservar-Ihe o espírito de anonimato, justamente

${ }^{126}$ Cf. T. Adorno, em Notas de literatura I, cit., p. 56.

${ }^{127}$ M. Bonati, Representation and fiction, cit., p.124.

${ }^{128}$ Os contos de Vita dei Campi (1880) foram originalmente publicados em revistas entre 1878 e 1880; o romance Os Malavoglia foi publicado em 1881.

${ }^{129}$ Em "L'Amante di Gramigna", p. 203.

130 Idem.

${ }^{131}$ Em "O narrador — observações acerca da Obra de Nicolai Leskow", cit., p. 58. 
porque procura não se distinguir "do discurso dos inúmeros narradores anônimos"132.

$\mathrm{Na}$ apresentação deste trabalho, já foi colocada a proposta de que a paródia e a estilização são as operações essenciais do método que Verga desenvolve para representar a realidade no seu romance, e construir o narrador impessoal perfeito. Expôs-se também a idéia de que os procedimentos paródicos a que o autor recorre apelam às raízes e à ancestralidade, de modo a engendrar esquemas de caráter universalizante e transcendente na narrativa. Ao se relacionar o princípio ativo e a funcionalidade dessa particularidade estilística com a teoria que Verga desenvolve sobre as verdades psicológicas como fonte do argumento do romance, é possível esboçar algumas idéias sobre como tais categorias fundamentam a técnica que o romancista desenvolve para produzir a ilusão de impessoalidade do narrador de Os Malavoglia.

Representar artisticamente o fato psicológico equivale a penetrar e desvelar uma série de arquétipos que simbolizam as situações que o sujeito, individual ou coletivo, vivencia. Segundo Meletínski, os arquétipos, por se referirem a correlações mútuas entre a interioridade do ser e o seu mundo externo, e em virtude de sua natureza simbólica e transcendental, constituem-se como unidades temáticas permanentes da literatura universal ${ }^{133}$. No seu romance, Verga explora inúmeros arquétipos literários (a serem analisados no capítulo seguinte), que, em camadas mais profundas da obra, funcionam como núcleos simbólicos carregados de ancestralidade, imemoriabilidade, conteúdo mitológico. Ao parodiar arquétipos e mitos, o autor os converte em fatores estéticos que se configuram como agentes da estrutura narrativa, cuja repercussão, no ato da leitura, ativa, na imaginação do leitor, os mesmos esquemas simbólicos que eles representam.

Em função da objectualidade intencional da obra ${ }^{134}$, o autor-narrador seleciona e manipula uma série de mitos de modo a estabelecer o "sistema dinâmico de símbolos" ${ }^{135}$ da universo ficcional. No caso específico do narrador que Verga constrói, tal recurso é utilizado como mecanismo de

\footnotetext{
132 Idem.

${ }^{133} \mathrm{Em}$ Os arquétipos literários, pp. 21-22.

134 Cf. A. Rosenfeld, "Literatura e personagem", em A. Candido, A personagem de ficção, cit., p. 31.

${ }^{135}$ Cf. E. Meletínski, em Os arquétipos literários, p. 34.
} 
despersonalização e isenção narrativa. De uma perspectiva processual, esse recurso, que é experimentado de modo ainda incipiente em "L'Amante di Gramigna" (como em outros contos de Vita dei campi) e elaborado com maestria no romance Os Malavoglia, vale-se da força arquetípica dos mitos que a narrativa recupera. A história de Peppa, que se deixa conduzir pela força hipnotizadora da lenda do herói popular Gramigna, ilustra muito bem tal processo. Os arquétipos atuam na esfera do inconsciente coletivo - onde não há individualidade, mas sim, um todo indivisível; e não há um tempo específico, mas sim, a atemporalidade, a eternidade; e dessa maneira, eles atingem em cheio o leitor, cuja energia psíquica, num processo de identificação sensívelintuitiva, é ativada pelo dinamismo simbólico que a narrativa propõe. Sem dúvida, este é um recurso poderoso para suprimir as barreiras que costumam delimitar as relações convencionais entre os elementos da comunicação artística: autor, obra e leitor ${ }^{136}$.

Como instância mediadora dessa tríade, o narrador de Os Malavoglia oculta-se do leitor, não por se diferenciar dele, do mesmo modo como não se diferencia de suas personagens; mas, ao contrário, por uma espécie de contaminação mimética. Em relação às personagens, esse processo se dá pela representação paródico-estilizada ${ }^{137}$ de elementos da realidade da comunidade retratada (linguagem, cultura, crença, mentalidade, valores morais, situações cotidianas e do trabalho etc.). Já no que diz respeito ao leitor, a tarefa de aproximação do narrador dá-se a partir da representação, também paródica, de temas arquetípicos (mitos, legendas, sabedoria popular, tradição oral, literaturas antiga, clássica e popular) que apelam a esferas subliminares de generalidade, primordialidade, perenidade; de modo a fazer com que o leitor identifique-se com a história narrada, a ponto de ter a impressão de estar circunscrito àquele universo, que mesmo sendo outro é o seu, pois a expressão artística irradia a essência do gênero humano.

O narrador segue à risca as regras do jogo que inventa de dissolver os limites individuais na esfera da coletividade, e sabe aproveitar-se muito bem disso para forjar a ilusão da impessoalidade narrativa. A representação de arquétipos literários no romance possibilita que o narrador simule o retorno a um

${ }^{136}$ Cf. A. Candido, em Literatura e sociedade. p. 22. 
estado pré-individual em que não se diferencia do todo. Neste ponto, há que se retomar o assunto já abordado dos princípios positivistas, de que o narrador de Verga também se vale nesta hora para incutir no seu discurso características de generalização típicas da formulação científica, procurando, dessa forma, validar a isenção de sua conduta.

Pode-se então arriscar uma resposta, parcial que seja, à pergunta lançada na apresentação deste trabalho: "Quanto do autor há neste narrador impessoal?" A visão crítica do escritor, que rege a intencionalidade da obra e transmite determinada ideologia, encontra, no processo de representação paródico-estilizada de arquétipos e mitos, uma chave que faz a sua mensagem individual diluir-se na generalidade da voz coletiva. Neste gesto de dispersão, a voz ideológica do autor ganha força, porque seu narrador faz-se representante da coletividade. Contudo, convém ressaltar que este narrador não se restringe a ser mero porta-voz de determinada ideologia, e nem tampouco facilita o próprio trabalho, pasteurizando as vozes da narrativa num só ramerrão ideológico. Ele orquestra cada uma delas, e também uma voz coletiva em que culminam todas as individuais, com tamanha precisão, que o leitor atento é capaz de perceber com nitidez cada uma das diferentes vozes sociais nela harmonizadas.

Redigido um mês antes da publicação do livro, o prefácio foi recomendado especialmente ao editor, numa carta que Verga enviou-lhe em agosto de 1880, com a primeira parte do manuscrito ${ }^{138}$. A recomendação, que a princípio parece um detalhe sem importância, ganha significado por indicar que o texto já tinha sido planejado pelo escritor como parte indissociável da obra, e sua ideação foise maturando ao longo do trabalho de redação do romance. "Em qualquer livro, o prefácio é, ao mesmo tempo, a primeira e a última palavra. Serve para explicar o objetivo da obra ou para justificar e responder às críticas" ${ }^{\text {"139 }}$, observa Liérmontov. No prefácio de Os Malavoglia, a voz do autor implícito ${ }^{140}$ é veiculada no prefácio por uma instância narrativa de estilo marcadamente naturalista, que, ao apresentar a intenção programática do escritor verista, e os

${ }^{137}$ Cf. M. Bakhtin, em Questões de literatura e de estética..., pp. 365-66.

${ }^{138}$ Cf. R. Scrivanno, em La narrativa di Giovanni Verga, p. 162.

${ }^{139} \mathrm{Em}$ "Prefácio do autor", O herói do nosso tempo, RJ, Ed. Guanabara, 1988, p. 11.

140 Cf. H. Grosser, em Narrativa - Manuale / Antologia, cit., p. $44 . \quad$ O termo é aqui empregado de acordo com a proposição de Grosser, de autor implícito como projeção de 
conceitos e métodos fundamentais de sua práxis, resgata suas raízes na tradição literária, ao mesmo tempo em que projeta suas funções artístico-sociais na trajetória da literatura contemporânea.

O prefácio evidencia os principais aspectos e traços constitutivos do romance, e orienta sua leitura para as questões específicas nele tratadas. Trata da estruturação e da organicidade do romance verista, justificando a escolha do objeto e dos critérios que regem sua representação, além de discorrer sobre o modus operandi do narrador impessoal. Aqui, o prefácio sustenta a unidade orgânica da obra, porque expõe os princípios básicos que "darão vida a todos os setores, colorindo cada um com suas particularidades qualitativas próprias" ${ }^{141}$. Tais fatores dão a liberdade de imaginar o prefácio como material e instrumento de calafetação da obra, cujo propósito é promover a "afinidade e a coesão"142 de cada uma de suas partes, garantindo que todas componham um só organismo - essa idéia é sintetizada no conceito de que "a forma é tão inerente ao sujeito, quanto cada parte do próprio sujeito é necessária à explicação do argumento geral" ${ }^{143}$.

Como definição do método de criação verista, que visa à reprodução artística exata da realidade, os preceitos apresentados dão ensejo a um processo de composição metonímico, de acordo com o qual, forma e conteúdo são atravessados por um único princípio de representação, que resulta e reverbera no todo. Desse ponto de vista, a concepção de Os Malavoglia como um romance-tese torna-se mais consistente, pois é possível entrever que a força integradora da organicidade estrutural da obra permite que nela coexistam ativamente o romance verista e a tese desse romance.

Nele, são apresentados os critérios do método de observação que o narrador desenvolve para compor uma narrativa que represente o objeto de maneira incontaminada, preservando integralmente suas particularidades. $\mathrm{O}$ narrador verista é idealizado como um observador imparcial que, ao contar a historia de uma pequena família siciliana subjugada às condições do presente histórico, restitui a "cena nitidamente, com as cores devidas, de modo a dar a

uma imagem literária associada ao escritor de determinada obra, a partir da perspectiva de suas convicções artístico-sociais.

${ }^{141}$ Cf. S. Eisenstein, em Reflexões de um cineasta., cit., p. 62.

142 Cf. G. Verga, em "L'Amante di Gramigna”, p. 204.

143 Cf. G. Verga, em "Prefácio", p. 8. 
representação da realidade como ela foi" ${ }^{144}$. Para tanto, ele procura identificarse plenamente com o seu objeto de representação, colocando-se como um observador arrastado pela mesma cheia, que olha "ao seu redor", com interesse "pelos fracos que ficam pelo caminho"145. Representar a realidade em toda sua complexidade, através de uma instância narrativa despersonalizada e imparcial, que seja capaz de deixar o objeto falar por si, é o cerne da problemática naturalista, e também a questão para a qual este romance-tese propõe uma solução.

O narrador verista utiliza a isenção e a neutralidade como critérios formais do seu método de composição da narrativa. A impessoalidade não deve ser verificada no resultado de seu trabalho, o relato em si, pois tal expectativa anteciparia a redução da prosa literária a um discurso narrativo pasteurizado, que rouba ao objeto de representação suas características originais e autenticidade expressiva. Esse procedimento é explicado no prefácio, ao se afirmar que o observador não tem o direito de julgar, sua tarefa é estudar o espetáculo "sem paixão"146 , para compor um relato sincero.

A fórmula de construção do narrador verista apresentada no prefácio prevê a ilusão da impessoalidade que é engendrada na narrativa. Tal artifício concede uma espécie de passe-livre para o narrador do romance, graças ao qual o leitor tende a dar por descontada a isenção da narrativa. Na defesa da tese verista, o prefácio explicita todas as etapas de concepção e criação do narrador do romance, para lançar com maior segurança as bases de sua construção. Desse modo, o "narrador oficial" do romance, é concebido ali, antes mesmo de a narração ter início; e, na explicitação de seus traços constitutivos, projeta-se a imagem do narrador verista ideal.

No prefácio são defendidos argumentos que preparam o leitor para a nova maneira de narrar, e o predispõem a aceitar os índices de subjetividade do discurso narrativo, como inerentes ao próprio objeto. No desenvolvimento dessa proposta no romance, a astúcia do narrador revela-se na sua capacidade de bem disfarçar o fato de que seleciona informações a dedo, e as organiza no esquema narrativo, de acordo com seus desígnios dramáticos. Apesar da

\footnotetext{
${ }^{144}$ Idem, p. 10.

${ }^{145}$ Idem, p. 9.

${ }^{146}$ Idem, Os Malavoglia, p. 10.
} 
orientação documentária e do cientificismo da literatura naturalista, ela também prescinde dessa "traição metódica", a partir da qual se estabiliza a relação entre narrador e leitor, pois a prosa ficcional não se caracteriza como tal, sem a consciência dessa brecha, o "quinhão da fantasia", que advém da "relação arbitrária e deformante que o trabalho artístico estabelece com a realidade"147.

O prefácio coloca que o narrador verista privilegia a observação de perto e o enfoque dos detalhes, a fim de evidenciar "todas as contradições, de cujo atrito brota a luz da verdade" ${ }^{148}$. Tal proposição remete ao princípio paródico que rege o método de representação do romance. Em Os Malavoglia, a paródia estabiliza-se como o princípio organizador da estrutura do romance, graças à continuidade do estilo do autor, que a adota como principal operação de representação; e a função artístico-social específica que tal mecanismo desempenha, distingue-se por articular a criticidade ativa do argumento em diferentes estratos da narrativa. É a partir dessa perspectiva, que a crítica ao caso social representado no romance dá-se de maneira oblíqua ${ }^{149}$. O narrador não formula expressamente qualquer opinião ou juízo; ele provoca o senso crítico do leitor, reunindo aspectos contrastantes do objeto.

A representação paródica desdobra-se numa operação de mão dupla, porque pressupõe a aproximação de dois planos, seja na imitação por oposição (paródia), seja, por identidade (estilização). O plano da obra é sobreposto ao plano do elemento parodiado, explica Tyniánov, e para que a paródia possa ser concebida como tal, e alcançar sua tenção reveladora, faz-se necessária a "desarticulação dos dois planos, o deslocamento de ambos" ${ }^{\text {"150 }}$. Nesse ponto, as proposições do escritor italiano e do teórico russo afinam-se: a paródia é uma operação literária, que produz um "atrito" revelador, aquele que dá chance à percepção da verdade subjacente da coisa.

$\mathrm{Na}$ representação do momento histórico, a população da província siciliana está à margem do desenvolvimento e da modernização característicos do século XIX, e vive o presente à moda antiga, de acordo com o regime de vida de seus antepassados. É a partir dessa perspectiva que, em Os

\footnotetext{
${ }^{147}$ Cf. A. Candido, em Literatura e sociedade, p. 13 (as três citações do período).

${ }^{148}$ G. Verga, em "Prefácio", p. 9.

149 Cf. Apresentação, p. vii.

${ }^{150}$ Em “'Dostoevskij e Gogol': per uma teoria della parodia”, p. 138.
} 
Malavoglia, o presente é paródia do passado. Em plena era da modernidade o mundo antigo subsiste. A visão de perto do observador verista consegue distinguir, em meio à "gloriosa luz" da "conquista do progresso"151, aqueles que ficam para trás - os "extenuados que se deixam ultrapassar pela onda"152. $\mathrm{Na}$ convivência paradoxal desses dois mundos, a inclinação específica do Naturalismo, que se interessa por dissecar um organismo em decadência, privilegia a observação do sistema social agonizante, e busca, no passado histórico local, as origens das questões críticas do presente.

Em resposta à questão da impessoalidade narrativa como fator determinante de uma representação realista da realidade, Os Malavoglia colocam em xeque a própria tese. Não há solução para o problema: a impessoalidade é (mais) uma convenção artística, e o romance naturalista só é possível, tal como ele se propõe, por meio da revolução do modo tradicional de narrar. A narração convencional não dispõe de recursos para conceber a complexidade da contemporaneidade, com todos os seus contrastes e disparidades. E nesse caso, a paródia, em razão do princípio de duplicidade que a caracteriza, apresenta-se como a única possibilidade de recriação crítica desse mundo. Em uma mesma operação paródica de representação, é possível combinar elementos opostos, que coexistem nesse mundo; ao se sobrepor o plano da antiguidade ao da atualidade, este último, por estar em vigor, desnudase em profundidade.

O velho modo de narrar não acompanha o compasso da história, e a sua estrutura não comporta a expressão da realidade atual. O narrador do prefácio trata desse "incessante movimento", que transcorre num "caminho fatal, ininterrupto" 153 , de acordo com o qual, o antigo modelo da arte de narrar baseada no princípio da sabedoria "tende para o fim"154, está em agonia. Veneno se cura com veneno, segundo o dito popular, e o narrador verista parece se inspirar nessa máxima para sanar o mal. Partindo do princípio da similitude ele recorre à estilização de tradições narrativas populares e literárias de todos os tempos, parodiando seus mitos, arquétipos, ícones e símbolos, de

\footnotetext{
${ }^{151}$ Cf. G. Verga, em "Prefácio", pp. 9-10.

152 Idem, p. 9.

${ }^{153}$ Idem, p. 8 (as duas citações respectivamente)

${ }^{154}$ Cf. W. Benjamin, em "O narrador - observações acerca da Obra de Nicolai Leskow", p. 58 (as duas citações respectivamente).
} 
modo a legitimar o caráter literário da língua literária e da instância narrativa que inventa para representar o novo objeto artístico em seu romance. 


\title{
A CONSTRUÇÃO DO NARRADOR: PARÓDIA E ESTILIZAÇÃO COMO PROCEDIMENTO
}

\begin{abstract}
O destino é obra dos deuses; se eles fiaram a ruína dos homens, foi para proporcionar poemas à posteridade. Sucumbiu diante de ílio algum teu parente? um bravo, talvez teu genro ou teu sogro, que vêm a ser os mais caros após os de nosso próprio sangue $e$ família? Ou quiçá um amigo devotado? porquanto um amigo compreensivo não vale menos que um irmão.
\end{abstract}

(Homero, Odisséia.)

Analisar a narrativa de Os Malavoglia é trabalho de arqueólogo. O estudo verista recupera o passado rico da região de Aci Trezza, onde a história se passa. A Sicília situa-se num ponto privilegiado, no qual convergem muitos "raios da história universal"155, observou Goethe. A ilha foi originalmente habitada por sicanos, vindos da Ibéria; e sículos, da Península ${ }^{156}$. Desde a idade do Bronze até a Unificação italiana, esteve sob diversas hegemonias, e abrigou civilizações de diferentes origens: grega, romana, bizantina, normanda, árabe, espanhola. Sua posição estratégica para a navegação nos mares Jônico e Mediterrâneo sempre atraiu embarcações de várias procedências, fenícios, vândalos, godos, sarracenos, sírios, judeus, germânicos, austríacos, ingleses passaram pela ilha ou nela se estabeleceram.

${ }^{155}$ Apud M. Aymard, em Storia d'Italia: Le regione dall'Unità a oggi - La Sicilia, cit., p. xx.

${ }^{156}$ Cf. E. Ciaceri, "Siculi e greci nella storia più antica della Sicilia", em Archivio storico per la Sicilia orientale, cit., p. 6. 
A Catânia (Katane) foi fundada em 729 a.C., durante o período da Magna Grécia. A intensa atividade comercial desenvolvida no seu porto beneficiou o crescimento da cidade. Contudo, por estar situada no sopé do Etna, a região sempre foi castigada por erupções, derramamentos de lava e terremotos, que submeteram a vida local a um ciclo imutável de construção-destruiçãoreconstrução ${ }^{157}$. As histórias do passado estão como petrificadas na sua natureza ${ }^{158}$, nas camadas do magma endurecido que se sobrepõem e formam a "sciara"159. Cada camada cobre determinado período histórico, e guarda as memórias dos povos que ali viveram, nos resquícios de suas culturas e costumes.

A estrutura narrativa de Os Malavoglia reproduz organicamente a geologia de Aci Trezza. O observador verista, ao propor o recorte do presente até as raízes, escava os campos de significados do objeto, e resgata vestígios das tradições culturais e narrativas dos povos colonizadores da Sicília oriental, fazendo-os convergir para o romance. O narrador, imitando o sistema da natureza, constrói um discurso narrativo estratificado, que apreende a complexidade de componentes da formação étnico-cultural da sociedade siciliana. Esse tipo de representação metonímica, em que forma e conteúdo são atravessados por um princípio único, que faz os elementos concorrem para o conjunto $^{160}$, estabelece uma dinâmica relacional de espelhamento, de acordo com a qual cada parte reflete o todo, dando chance à composição de camadas narrativas orgânicas, que refratam significados mais abrangentes da obra.

Tal como ocorre na vida real, em que cada geração porta características, usos e costumes das gerações passadas, essas camadas narrativas não são estanques, em cada uma delas coexistem resquícios das tradições e culturas

${ }^{157}$ Cf. M. Aymard, em Storia d'Italia: Le regione dall'Unità a oggi - La Sicilia, p. xxi. Escreve o autor: "E por toda parte, nas planícies e colinas, os traços indeléveis - ruínas de templos e restos de tesouros, trajetos viários, escombros de fortalezas, cinturões urbanos rachados e castelos vazios - da grandeza política, da piedade suntuosa do passado siciliano."

${ }^{158}$ Idem, p. xxiii.

159 Relevo típico da região de Aci Trezza, composto de camadas endurecidas do magma vulcânico derramado.

${ }^{160}$ Cf. S. Eisenstein, em Reflexões de um cineasta, p. 62. 
anteriores. O prólogo ${ }^{161}$ é um bom exemplo para investigar como se dá a organicidade estrutural e conteudística nesse tipo de construção narrativa, pois traz uma amostra dos estratos culturais explorados, reúne elementos recorrentes e desenvolve procedimentos que repercutem em todo o romance. $\mathrm{O}$ fracionamento do texto em três partes, definidas por suas características e funções narrativas específicas, permite que sejam destacados não só os índices das tradições culturais e narrativas contidos em cada uma, como também as operações paródicas efetuadas para representá-los e a significação que reportam para ao interior da obra.

Em outros tempos os Malavoglia tinham sido numerosos como as pedras da estrada velha de Trezza; e deles havia até em Ognina, e em Aci Castello, todos boa e brava gente do mar, bem ao contrário do que parecia pela alcunha, como sói acontecer. Realmente, no livro da paróquia chamavam-se Toscano, mas isso não queria dizer nada, pois desde que o mundo é mundo, em Ognina, em Trezza e em Aci Castello, sempre tinham sido conhecidos como os Malavoglia, de pai para filho, que sempre tiveram barcos na água e telhas ao sol. (p.13)

O cronotopo inicial do romance ${ }^{162}$ remete às origens, à vida dos antepassados e suas tradições. Nesse estrato narrativo, os dados genealógicos da família são recuperados nos vestígios das primeiras civilizações da região. Os Malavoglia, por serem "todos boa e brava gente do mar", estão ligados ao universo cultural das navegações mediterrâneas. O seu modo de ganhar a vida, que "sempre tiveram barcos na água e telhas ao sol", reproduz a tradição do trabalho e a economia de antigas comunidades de origem grega, que povoaram o lugar. A transmissão "de pai para filho" dos conhecimentos, valores e costumes, pautados na ordem patriarcal, remonta às raízes da família grecoromana. Essas declarações, que exaltam os ancestrais e o ideal do passado nacional, como um artifício de glorificação da própria raça, são formuladas ao

\footnotetext{
${ }^{161}$ Nesse estudo entende-se que o prólogo é composto dos sete parágrafos iniciais do capítulo I (de: "Em outros tempos os Malavoglia"; até: "quem tem mando não abandona o comando" - pp. 13-15).

${ }^{162}$ Cf. M. Bakhtin, em Questões de literatura e de estética...., pp. 211-212.
} 
estilo da tradição épica, e engendram na narrativa fortes traços constitutivos do gênero.

O "livro da paróquia", que traz o verdadeiro sobrenome da família, é documento da Igreja católica romana, instaurada efetivamente na região durante o domínio normando ${ }^{163}$. O fato de o sobrenome do registro da igreja ser Toscano, que não quer "dizer nada", na verdade, diz muito: a tradicional família siciliana é de ascendência setentrional ${ }^{164}$. A projeção da origem dos antepassados no plano narrativo da contemporaneidade, que diz respeito ao conturbado período da Itália recém-unificada, evidencia a marca ideológica de cunho unionista, como fator determinante da narrativa; não há razão palpável que justifique o separatismo, que, durante muito tempo, determinou a fragmentação política da península.

$\mathrm{Na}$ representação da máscara familiar, a articulação do duplo ToscanoMalavoglia contrapõe a natureza dinâmica dos primeiros ancestrais que vieram do continente em busca de melhores condições de vida, ao sedentarismo das gerações posteriores, estabelecidas em Ognina, Trezza e Aci Castello "desde que o mundo é mundo". O apelo trágico do primeiro estrato narrativo do prólogo fica por conta desse motivo patético (a total inversão do modo de vida) que a história da família guarda.

[...] Agora em Trezza só restavam os Malavoglia do patrão 'Ntoni, aqueles da casa da nespereira, e da Providência que ficava na encosta do areal, debaixo do lavadouro, perto da Concetta do tio Cola, e da chalupa do patrão Fortunato Cipolla.

As borrascas que dispersaram os demais Malavoglia de uma banda e de outra tinham passado sem causar grande dano à casa da nespereira e ao barco amarrado debaixo do lavadouro; e o patrão 'Ntoni, para explicar o milagre, costumava dizer, mostrando o punho fechado -- um punho que parecia feito do lenho da nogueira - Para manejar o remo é preciso que os cinco dedos se ajudem uns aos outros.

\footnotetext{
${ }^{163}$ A Sicília esteve sob o domínio dos normandos no século IX.

${ }^{164}$ O sobrenome deriva de indicador étnico, e significa "gente da Toscana".
} 
Dizia ainda: - Os homens são como os dedos da mão: o dedão deve agir como dedão, e o dedo mindinho como dedo mindinho.

E a família do patrão 'Ntoni estava realmente disposta como os dedos da mão. Primeiro vinha ele, o dedão, que comandava as festas e as quarenta horas; depois seu filho Bastiano, Bastianazzo, porque era alto e corpulento como o São Cristóvão pintado sob o arco do mercado de peixe da cidade; e assim alto e corpulento como era, cumpria à risca a tarefa ordenada, e não teria assoado o nariz sem que o pai lhe tivesse dito "assoe o nariz", tanto que se casara com a Longa quando the disseram "case-se com ela". Depois vinha a Longa, mulher miúda que cuidava de tecer, salgar as anchovas, e fazer filhos, como uma boa dona-de-casa; finalmente os netos, por ordem de nascimento: 'Ntoni, o mais velho, um mandrião de vinte anos, que vivia levando pescoções do avô, e pontapés mais abaixo para recuperar o equilíbrio quando o pescoção tinha sido forte demais. Luca, "que tinha mais juízo que o mais velho" na opinião do avô; Mena (Filomena), apelidada de "Santa Ágata" por estar sempre ao tear, e costuma-se dizer "mulher de tear, galinha de galinheiro, salmonete de janeiro"; Alessi (Alessio), um ranhento que era o avô escrito e borrado!; e Lia (Rosalia), ainda nem coisa e nem loisa. Aos domingos, quando entravam na igreja, um atrás do outro, parecia procissão.

O patrão 'Ntoni sabia também certos motes e provérbios que ouvira dos antigos, "porque dos antigos o mote não mente jamais": - "Sem piloto a nau não dá quinau" - "Para ser papa é preciso saber ser sacristão" - ou ainda - "Faze o trabalho que conheces que, se não enriqueces, de fome não morrerás" - "Contenta-te com o que de ti fez o teu pai; se não fores outra coisa, pelo menos tratante não serás" e outras sentenças judiciosas. (pp. 13-15)

O cronotopo da atualidade ("Agora em Trezza") introduz o segundo estrato narrativo do prólogo, que se refere particularmente à história de vida dos "Malavoglia do patrão 'Ntoni". A seleção e organização dos traços que compõem a imagem da família, bem como a explicitação dos vínculos que ela 
estabelece com a comunidade são elementos de composição que reportam a antigas memórias autobiográficas de famílias romanas patrícias, nas quais eram descritas sua genealogia, funções públicas e relações sociais ${ }^{165}$.

Nessa apresentação da família tradicional de Trezza, os sinais da decadência do clã são evidenciados, e revelam o estado arqueológico do grupo familiar contemporâneo (o único ramo que resta da antiga linhagem), cujo histórico, recuperado pela narrativa, acumula as ruínas e desgraças dos antepassados. A história dos Malavoglia, repleta de peripécias marítimas, traz temas e motivos de velhas narrativas de viagens. "O mar é cruel e o marinheiro morre no mar", repetem os Malavoglia, em diversas situações do romance, expressando uma espécie de fórmula concentrada da experiência familiar.

O princípio metonímico do método de representação desenvolvido no romance sustenta, na estrutura narrativa, diversos planos de enfoque. $O$ narrador dirige a focalização principal para a vida da família; e dispõe uma série de focos narrativos menores, ou secundários, que alcançam outros núcleos do universo social de Trezza, os quais se configuram como extensões da história principal. $O$ trecho de abertura desse estrato explicita tal procedimento: a imagem da família é construída e estabelecida como ponto referencial da narração, a partir do qual são projetados os outros planos de enfoque, que incidem sobre os lugares onde a vida pública do povoado decorre, tal como os exemplos citados, do areal e do lavadouro, local de trabalho dos homens e das mulheres, respectivamente. Esse jogo dos focos narrativos deixa claro que o enredo concentra-se na história familiar, e as tramas paralelas são desenvolvidas somente na medida em que interferem na vida da família, ou especificamente no destino de algum dos parentes. Mais uma vez, o narrador parece inspirar-se na realidade geológica da região para armar a estrutura e ajustar as lentes da narração, como se o foco narrativo principal correspondesse à imensa cratera do Etna, e os demais, às menores que se espalham ao seu redor. A refração do relevo do lugar na estrutura formal do romance (como nos casos da disposição dos focos narrativos, da segmentação do discurso narrativo em estratos, e do sistema das instâncias narrativas) configura-se como um poderoso recurso de representação realista do ambiente,

${ }^{165}$ Cf. M. Bakhtin, em Questões de literatura e de estética...., p. 256; e em Estética da 
de acordo com o qual, sem que haja descrições sistemáticas do espaço geográfico, ele seja facilmente depreendido através da leitura.

Os epítetos atribuídos à família ("os Malavoglia do patrão 'Ntoni" e "aqueles da casa da nespereira e da Providência") retratam a sua posição social e o seu patrimônio. Isso indica que a concepção da imagem familiar, no interior da própria comunidade, tem por base os critérios de ordem econômica. "Os homens são como os dedos da mão: o dedão deve agir como dedão, e o dedo mindinho como dedo mindinho", reza o provérbio do patrão 'Ntoni. No quadro da comunidade, o título da personagem (patrão) indica que a família tem propriedade e trabalha por conta própria. Na organização hierárquica de Trezza são levados em conta os bens e a capacidade de produção dos indivíduos. A decrepitude dessa estrutura deixa-se entrever na importância que os valores materiais adquirem nessa sociedade marcada historicamente pela pobreza. Os escassos recursos e as pequenas propriedades dos habitantes de Trezza parecem não ser suficientes para preencher a grandeza que os velhos títulos hierárquicos evocam.

Os provérbios que explicam a permanência da família no decorrer dos tempos refletem uma filosofia de vida toda voltada para o trabalho. Eles projetam modelos de subsistência cristalizados, que traduzem um mundo onde tudo é feito com as próprias mãos, à custa de muita força e do sacrifício de todos pelo bem comum: "Para manejar o remo é preciso que os cinco dedos se ajudem uns aos outros."

A profissão de pescador é uma das poucas possibilidades de sobrevivência nesse sistema social arcaico e fechado; moldado por valores axiológicos que carregam a marca do conformismo e da resignação: "Contentate com o que de ti fez o teu pai; se não fores outra coisa, pelo menos tratante não serás", diz o ditado; ou ainda, "Faze o trabalho que conheces que, se não enriqueces, de fome não morrerás." Esses provérbios encerram conceitos e princípios morais que datam da Idade Média, são resquícios culturais do feudalismo que vigorou na região por séculos.

A construção da imagem do chefe da família dá-se em mão dupla, pela articulação de traços constitutivos de significações opostas. Num primeiro plano,

criação verbal, p. 213. 
a objetivação do conjunto de dados selecionados pelo narrador esboça determinada faceta da máscara da personagem. O perfil do patriarca é traçado: chefe de família respeitado pela comunidade, proprietário de uma casa conhecida de todos e de uma das poucas barcas de pesca do lugar. Homem simples e conservador, calejado pelo ofício, segue o modo de vida e o código moral dos ancestrais. Sua concepção de mundo é explicitada nos provérbios e aforismos que vive a repetir como se fossem mandamentos. A contrapelo dessa representação, a simbologia dos traços caracterizadores da personagem decalca toda uma camada de significados não aparentes, que configuram outra face da máscara.

Os dois ícones da família, que compõem o seu epíteto, referem-se ao sentimento religioso: a casa da nespereira retoma a "religião da família" ${ }^{166}$, que preza o trabalho e o lar; a barca batizada de Providência representa o temor e a reverência ao árbitro divino. A conjunção de dois símbolos correlatos reforça os atributos a que eles remetem, caracterizando o exagero: devoção fervorosa, crença cega no destino, submissão à lei celestial. O punho do patrão 'Ntoni "feito do lenho da nogueira" denota força física e experiência adquiridas na lida diária do trabalho, demonstrando a adaptação mimética do homem ao seu ofício. Esses predicados ganham um colorido especial pela refração de seus significados simbólicos: a nespereira é associada à parvoíce e estultice; a Providência e a nogueira relacionam-se com 0 dom da profecia e o conhecimento antecipado do futuro ${ }^{167}$.

Desse ponto de vista, a imagem da personagem construída no plano superficial esfacela-se, porque se mostra destituída de conteúdo real. A falta de discernimento do patrão 'Ntoni redunda na aceitação inquestionável de ideais, valores e normas de um passado absoluto, acumulados em formas proverbiais estropiadas, que são empregadas para alicerçar e conduzir o modo de vida atual. A estreiteza de visão confere-lhe um dom de profecia que só enxerga a possibilidade única de o presente e o futuro serem iguais ao passado, ou ainda, o que parece ocorrer, espelharem as ruínas do passado, que são a única forma dos tempos imemoriais que o velho 'Ntoni e toda a gente de Trezza conhecem.

\footnotetext{
${ }^{166}$ Alegoria filosófica criada por G. Verga (cf. pp. 19-20).

167 Cf. Dictionnarie des symboles - mythes, réves, coutumes, gestes, formes, figures, couleurs, nombres, cit.
} 
Essa imagem equívoca da personagem, perceptível pelo descompasso dos planos objetivo e subjetivo de sua representação, prepara o leitor para a hybris cometida no final do primeiro capítulo, graças a um desvio do patriarca de sua conduta habitual: se pudesse realmente antecipar o futuro, o avô não teria fechado o negócio dos tremoços, que acaba causando a derrocada da família. Desse modo, o prólogo antecipa, na forma de motivo trágico, a transgressão que rompe a normalidade da vida familiar, o estado inicial de equilíbrio da época em que a "casa da nespereira prosperava", retratada no prólogo.

No mecanismo de construção da imagem das personagens, esse procedimento, que dispõe significações controversas de um só conteúdo, nos vários estratos de uma mesma camada narrativa, corrobora com outro, que faz reverberar um mesmo significado em camadas narrativas diversas. Se, num certo fragmento do romance, um conteúdo significativo é resguardado no substrato narrativo, num outro, posterior a esse, tende a ser exposto na camada superficial, escancarando um sentido que até então permanecia velado. Esse método de composição propicia a interação orgânica das camadas do discurso narrativo, graças à continuidade estilística do narrador como portador de todas as vozes; e pode ser observado, ainda no caso da construção da imagem do patrão 'Ntoni.

As duas primeiras camadas do prólogo guardam, no interior da narrativa, o conteúdo implícito relativo à significação simbólica dos traços caracterizadores descritos até então. Nos dois parágrafos que fecham o prólogo, a situação se inverte, e o teor desse conteúdo é explicitado, quando o narrador reproduz o senso comum do vilarejo: "o patrão 'Ntoni passava por pessoa com a cabeça no lugar, a ponto de que em Trezza tê-lo-iam nomeado conselheiro municipal”168.

Tal argumentação mostra-se pouco consistente, e suscita no leitor dúvida razoável acerca do que foi afirmado. O fato de o patrão 'Ntoni 'passar por' homem ajuizado, e 'quase' ter sido conselheiro municipal indica que, por detrás da aparência, escondem-se elementos que a desmentem. Em seguida, ao citar a opinião de dom Silvestro, de que o velho não passa de um "caturra empedernido" e "um reacionário", o narrador mostra o outro lado da moeda. $\mathrm{O}$ 
secretário, em razão de sua condição de forasteiro, dispõe de uma visão diferenciada daquela de senso comum da aldeia, e, mesmo ao se levar em conta a parcialidade do seu julgamento, moldado na medida exata dos interesses próprios, que estão em jogo no conselho do município, quando a narrativa registra a sua opinião, as cartas são lançadas e marcam a imagem da personagem.

O narrador organiza as camadas narrativas, de modo que os seus conteúdos (temas, motivos, atributos) são continuamente reiterados. A narração é marcada por essas antecipações; o desenvolvimento da trama não guarda surpresas, pois tudo o que acontece já foi previamente tramado no tecido narrativo.

E a família do patrão 'Ntoni estava realmente disposta como os dedos da mão. (p.14)

O parágrafo que descreve a composição da família é o mais substancioso do prólogo, e concentra em si a essência do romance, pois nele são lançados os fundamentos da construção das imagens das personagens centrais da história. No estrato superficial da narrativa é traçado um breviário familiar, que parodia antigas autobiografias de famílias romanas. Cada Malavoglia é classificado de acordo com a ordem "dos mais velhos", e caracterizado por seus atributos distintivos. A formalidade documental é quebrada pelos elementos afetivos do texto - os hipocorísticos precedem os nomes próprios, e os dados apresentados misturam aspectos da vida pública e da intimidade familiar. A paródia do registro documental é caracterizada pelas particularidades do estilo de uma instância narrativa interior (a fonte das informações que o narrador verista reproduz), que aparentemente não tem pleno domínio das convenções do gênero, e recorre a clichês e lugares-comuns para compor a memória da família.

Os traços constitutivos de cada Malavoglia refletem a simbologia do universo familiar e social de Trezza; pois a composição das máscaras das personagens dá-se pela representação paródico-estilizada de seus mitos,

168 Os Malavoglia, p. 15 (Doravante, as citações de trechos do romance serão referidas pelo título). 
crenças, ícones, provérbios, gestos, usos e costumes, resgatados nas suas tradições culturais. Os vários campos de significados, concernentes a esses elementos, irradiam-se por toda a narrativa, e marcam o desenvolvimento do enredo.

As descrições concisas que retratam as personagens compõem imagens cristalizadas, carregadas de elementos simbólicos, os quais, graças a sua significação transcendente, prenunciam o destino de cada uma na biografia familiar. O recurso configura-se como mais uma peça do mecanismo de antecipação da trama, que, trabalhando em favor da unidade orgânica da obra, organiza a composição narrativa de modo que cada parte reflete o todo - no começo está contido o final da história, assim como o final redunda no começo...

Esse estrato do prólogo expõe o panteão das divindades cultuadas pelos povos que habitaram na região, desde a era pagã. A enformação das personagens faz convergir, para o interior da narrativa, resquícios das crenças e das tradições religiosas de todos os tempos. A caracterização do avô como o responsável pelas práticas religiosas, a alusão a elementos que remetem a certos mitos mediterrâneos de épocas primordiais, a atribuição de nomes de santos cristãos a todos os familiares, a associação da Mena a Santa Ágata, a referência ao costume de ir à missa aos domingos, a comparação da família com uma procissão, são índices compositivos que esboçam o universo místicoreligioso de Trezza.

O resgate paródico de velhas lendas mediterrâneas, que evocam mitos de crenças ancestrais, é feito em um substrato narrativo que atua na construção das máscaras de Bastianazzo e de sua mulher, a Longa.

Longa é o nome de um dos farilhões "dos Ciclopes", que ficam em frente à praia de Trezza169; e as características físicas do Bastianazzo, por ser "alto e corpulento", lembram as desses seres mitológicos gigantescos ${ }^{170}$. A

${ }^{169}$ As ilhas (ou farilhões) dos Ciclopes, em frente à enseada de Trezza são denominadas: Longa, Zu lanu di terra, Zu lanu di fora (lanu, em sículo, corresponde a Bastiano), e Lachea.

${ }^{170}$ Segundo a lenda, em época muito remota, os ciclopes viviam nas redondezas do Etna e da costa da Catânia. Eram gigantes de um só olho no meio da testa e força descomunal; antropófagos, e coléricos. O mito relaciona-se com a geografia da região, caracterizada pelo vulcão e as inúmeras crateras menores. O aspecto gigantesco e o olho único dos ciclopes correspondem à forma do vulcão; seus atos de violência repentina são 
denominação do arquipélago rochoso advém de uma lenda que narra a sua formação, protagonizada por Polifemo, o ciclope filho de Posidão e personagem de vários outros poemas de navegações e lendas sicilianas, que remontam ao período da colonização grega (IX e III a.C. ${ }^{171}$ ).

Essa mesma narrativa foi recuperada pela Odisséia ${ }^{172}$, numa das aventuras do retorno de Ulisses a Ítaca (canto IX). O herói e alguns companheiros desembarcam na região, e são aprisionados por Polifemo. Cegado pelos homens de Ulisses, que do barco lança-Ihe impropérios, que o enfurecem, "ele, então (...); arrancou o pico duma grande montanha e arremessou-o; acertou à frente do barco de escura proa." Não satisfeito, o herói desacatou-o uma segunda vez, e, novamente, o gigante "apanhou um penhasco muito maior, rodopiou e arremessou-o"173. A referência, no prólogo, a elementos desse episódio é bastante significativa, pois caracteriza uma marca de intertextualidade que se estabelece entre o romance verista, como camada narrativa mais recente, e o poema homérico, considerado, por sua vez, um dos primeiros exemplos de narrativa romanesca da antiguidade clássica.

Resquícios culturais do lendário "país dos arrogantes e iníquos Ciclopes" ${ }^{\text {174 }}$ subsistem na comunidade contemporânea de Trezza. Os atributos simbólicos do mito revelam-se na caracterização de personagens masculinas. A força bruta, a irascibilidade e a grosseria ciclópicas modelam o tipo físico, o comportamento e as atitudes dos homens "de fígados" da aldeia.

[...] nesse dia depois do almoço divertiram-se trocando socos com o compadre Pizzuto, que não tinha medo nem de Deus, apesar de não ter sido soldado, e que foi rolar por terra na frente da taverna, com o nariz cheio de sangue; mas, em compensação, o Rocco Spatu foi mais forte e derrubou o 'Ntoni aos seus pés.

associados às erupções. De acordo com a tradição grega, os ciclopes simbolizam a força bruta desenfreada, de natureza primitiva e retrógrada. Eles servem a Zeus e trabalham sob as ordens de Hefesto. (Cf. Dictionnarie des symboles - mythes, réves, coutumes, gestes, formes, figures, couleurs, nombres.)

${ }^{171}$ Cf. E. Ciaceri, em "Siculi e greci nella storia più antica della Sicilia", pp. 3-4; e L. Bernabò Brea, Sicília, cit.; e www.acitrezzaonline.it.

172 Cf. R. Aubreton, em Introdução a Homero, cit., p. 168.

${ }_{173}$ Cf. Homero, Odisséia, cit., pp. 111-112, respectivamente.

${ }^{174}$ Idem, p. 103. 
- Puxa vida! exclamaram os que estavam assistindo. Este Rocco é forte como o mestre Turi Zuppiddu. Gostasse de trabalhar, ganharia bem o seu pão!

- Eu só sei rezar por este catecismo aqui! dizia o Pizzuto mostrando a navalha, para não se dar por vencido.

Enfim, o 'Ntoni passou o dia inteiro se divertindo [...] (pp. 84-

5)

A imagem do mestre Turi Zuppiddu, o calafate, é a mais arquetípica. Os elementos, instrumentos e gestos do seu ofício - fogo, caldeirão, alcatrão, piche, formão - associam-se à simbologia do Etna, onde os ciclopes trabalham, sob as ordens de Hefesto.

[...] e percebia-se o mestre Turi Zuppiddu cantar à toda voz, com aqueles seus pulmões de boi, enquanto batia com o formão, e o cheiro do alcatrão que vinha da praia [...] $\quad$ (p. 68)

A compleição física, o ofício, o sobrenome (cujo significado é "manquitola") e o nome de sua mulher, Venera (Vênus), revestem a personagem com elementos do mito de Hefesto, o deus coxo, mestre da arte do fogo, casado com Vênus, a deusa do amor.

A mentalidade e os valores de senso comum, que permeiam as relações sociais, também são marcados pelo simbolismo dos Ciclopes. Vestígios de sua natureza, dominada pelo egocentrismo, e por forças primitivas e retrógradas, transparecem nas regras de convivência da família e da comunidade - seja na atitude do patrão 'Ntoni, que manda e desmanda na própria casa, como diz dom Silvestro; ou ainda, na de uns e outros, como o Piedipapera, que defendem seus interesses com unhas e dentes, e costumam usar os provérbios para justificarem suas desculpas: "Sinto muito, patrão 'Ntoni; dissera-lhe: mas o que você quer? Preciso pensar nos meus interesses. São José fez a barba primeiro e só depois fez a dos outros" ${ }^{\text {"175 }}$.

${ }^{175}$ Os Malavoglia, p. 162 (grifo nosso). 
Esses traços esboçam um quadro da terra de Trezza contemporânea, que pouco difere daquele da época primitiva, descrito por Ulisses ao observar a sociedade dos ciclopes:

Não têm praças de assembléia, nem leis estabelecidas; moram na crista de altas montanhas, no seio de cavernas, e cada qual dita leis aos filhos e esposas, sem se preocuparem uns com os outros. ${ }^{176}$

A tradição cristã é resgatada pelos elementos que compõem a imagem dos membros da família; a começar por seus nomes, que remetem a santos da fase inicial do Cristianismo - mártires, virgens, anacoretas, pregadores, que são patronos de localidades da região e protetores de profissões, atividades, emblemas de objetos, plantas, animais e alimentos de oferenda.

A intertextualidade com hagiografias cristãs vincula o romance verista ao antigo romance de provação ${ }^{177}$. Essa ligação, estabelecida a partir da enformação das personagens centrais, configura-se como fator determinante do esquema do enredo, pois faz convergir o ideal dogmático da modalidade hagiográfica para a narrativa romanesca, definindo o encaminhamento da trama. Nesse sentido, a representação paródico-estilizada do romance de provação propicia a transposição da característica principal do gênero, a imutabilidade dos caracteres, para a enformação das personagens do romance verista: "o herói da provação é acabado e predeterminado, as experimentações (sofrimentos, seduções, dúvidas) não se tornam para ele uma experiência formadora nem o modificam" ${ }^{178}$. Na organicidade macroestrutural do romance, a conjuntura desses elementos compositivos evidencia a inalterabilidade do tipo de vida retratado — os acontecimentos da história da personagem não culminam numa vida nova, apenas confirmam o modelo habitual.

O nome da personagem determina o seu duplo, e a representação paródica da legenda do santo respectivo atua na construção da máscara, condicionando-a. Esse recurso de composição permite que elementos da tradição hagiográfica permeiem a narrativa e consubstanciem a imagem da

\footnotetext{
${ }^{176}$ Homero, Odisséia, p. 103.

177 Cf. M. Bakhtin, em Estética da criação verbal, pp. 207-08.

${ }^{178}$ Idem, p. 209.
} 
personagem. A legenda marca, por assim dizer, essa imagem, seja pelo empréstimo de características físicas e psicológicas, ou pela determinação da trajetória de vida. A personagem é destinada a reproduzir o mesmo modelo de existência, passando por provações, desejos, sofrimentos e alegrias (poucas) que simulam aquelas da vida do santo que lhe empresta o nome. Os limites desse acondicionamento, que o simbolismo dos traços caracterizadores impõe, são reforçados por aqueles do "bloco descritivo" que acompanha cada nome, e retrata os atributos elementares de cada personagem. Esse retrato mostra uma imagem que a narrativa perpetua, confirmando-a em cada passo da trama; não há desenvolvimento ou transformação dos caracteres. O destino de cada um é marcado por aquilo que prediz o mito, a legenda, o provérbio, o lugar-comum.

O destino de Mena é ser a Santa Ágata — é o que diz o seu apelido; a reverência das comadres, "Oh! Santa Ágata!"179; o elogio do avô, "Muito bem, Santa Ágata!"180 Já no prólogo, o provérbio "mulher de tear, galinha de galinheiro, salmonete de janeiro", que determina o comportamento exemplar de toda mulher de família, serve-lhe de guia e atributo, como serviu a sua mãe. O nome de batismo, Filomena, remete à santa homônima, e desvela uma outra face da máscara da personagem, que endossa todos esses atributos, pois Santa Filomena, que é de uma geração posterior à de Santa Ágata, caracteriza-se como uma continuadora da sua tradição. As duas santas vigoram no mesmo cânone das virgens, mártires e seviciadas, do ciclo das persecuções romanas aos cristãos.

A Mena se conforma com o que fazem da sua vida; o avô, agindo de acordo com o ditame da tradição, traça o destino da neta:

O patrão Cipolla continuava a fazer que sim com a cabeça, tanto mais que entre ele e o patrão 'Ntoni tinham sido feitos alguns acertos para casar a Mena com seu filho Brasi, e se o negócio dos tremoços corresse bem, a Mena teria seu dote em metal sonante, e o trato logo seria fechado. (pp. 31-2)

\footnotetext{
${ }^{179}$ Os Malavoglia, p. 36.

${ }^{180}$ Idem, p. 217.
} 
Ironicamente, a personagem tem menos opções do que as santas associadas a sua imagem, as quais, segundo a legenda, renegaram pedidos de casamento de figurões do Império romano e resistiram às retaliações a que foram submetidas, graças à fé inabalável. A Mena solapa o sentimento que traz no peito, pelo compadre Alfio, em nome das regras familiares, determinadas pelo sistema social estratificado e fechado de Trezza, que prevê o casamento entre indivíduos da mesma classe - a neta do patrão 'Ntoni deve se casar com o filho do patrão Fortunato Cipolla.

- Já temos metade do dinheiro para dar ao Piedipapera e com a salga das anchovas pagaremos o resto.

O Alfio, ao ouvir esta fala, largou o burro no meio do quintal, e veio até a rua. - Então vão casá-la depois da Páscoa?

A Mena não respondeu. - O que foi que eu lhe disse? acrescentou o compadre Alfio. - Bem que eu vi o patrão 'Ntoni de conversa com o patrão Cipolla.

- Será como Deus quiser! disse então a Mena. Não me incomodava de casar, contanto que me deixassem ficar aqui.

- Que beleza, ajuntou o Mosca, quando se é rico como o filho do patrão Cipolla, que pode se casar com quem quiser e ficar onde Ihe aprouver! (pp. 130-31)

As desgraças se acomodam de tal jeito, que a Mena vê-se obrigada a renunciar definitivamente ao casamento, e se consola com um arremedo de maternidade, dedicando-se a criar os filhos do irmão caçula. Mesmo depois da ruína da família e do desgaste do velho código moral, ela se vê impedida de aceitar o pedido do carroceiro Alfio Mosca:

- Eu já não sou moça para me casar - tornara a dizer a Mena; - case-se você, que ainda está na idade; e assim, ela tinha subido para o sótão da casa da nespereira, como as caçarolas velhas, e sossegara o coração, esperando os filhos da Nunziata para criar.

$[\ldots]$ 
O compadre Mosca abanava a cabeça ao vê-la passar, e virava-se para o outro lado, com aquele peso nas costas. - A mim não me julgou digno desta honra! disse-lhe por fim, quando não agüentou mais, com um peso maior no coração do que nas costas. - Eu não era digno de que me dissesse sim!

- Não, compadre Alfio! - respondeu a Mena, que sentia as lágrimas aflorarem. - Por esta alma pura que trago no colo! Não é esse o motivo. Mas já não sou moça para me casar.

- Por que não, comadre Mena?

- Não! não! - repetia a comadre Mena, quase chorando. Não me obrigue a dizer, compadre Alfio! Não me obrigue a falar! Se me casasse agora, as pessoas voltariam a falar da minha irmã Lia, porque ninguém se atreveria a casar com uma Malavoglia, depois do que aconteceu. Você seria o primeiro a se arrepender. Esqueça-me, que não sou moça casadoura, e sossegue o coração.

- Você tem razão, comadre Mena! respondeu o compadre Mosca; - nisso eu nunca tinha pensado. Maldita sorte, que trouxe tanto infortúnio! (pp. 325-26)

A legenda refrata o padrão de comportamento feminino, que, arraigado no sistema axiológico dessa sociedade, serve como modelo de enformação da personagem contemporânea, pois reproduz uma das poucas opções de vida, que a mulher solteira tem no esquema social de Trezza.

A outra opção coube à Lia. A Mena não pode mais se casar por causa do destino da irmã, marcado pela legenda de Santa Rosalia - jovem não mártir, nascida na Sicília durante o período de renovação cristã instaurado pelo rei normando, que abandonou a casa dos pais, para viver como eremita numa caverna. E é o que, mais ou menos, acontece com a Lia, por não ser "nem coisa e nem loisa". A caçula tem um comportamento "renovado", que não lembra em nada o da Santa Ágata:

Mas a Lia era mais estouvada do que o irmão 'Ntoni, e gostava de ficar à porta, exibindo o lenço com estampa de rosas, porque todos 
Ihe diziam: - Como você fica linda com este lenço, comadre Lia! e dom Michele devorava-a com os olhos. ${ }^{181} \quad$ (p. 258)

Como representante de uma nova geração, a personagem está mais apta a enxergar os sinais da decadência familiar, que a rigidez do código moral camufla; por isso, sem outra saída, a moça tende a guiar seu comportamento pela sua vontade própria, e não exatamente por aquilo que as regras da família e da comunidade ditam:

[...] para não perder a caminhada, dom Michele tinha lançado olhares à Lia, que também se tornara uma bela moça e não tinha ninguém para tomar conta dela, a não ser a irmã, que corava em seu lugar e Ihe dizia: - Vamos para dentro, Lia. Não fica bem estar à porta, agora que somos órfãs. [...] e a Lia respondia: - Tem medo de que ele me coma? Pois sim, ninguém quer saber de nós, agora que não temos mais nada. Não está vendo como acabou o nosso irmão, que nem os cachorros o querem? (p. 258)

As atitudes da moça acabam se virando contra ela, pois são usadas, oportunamente, pelo advogado Scipione, como argumento principal de defesa no julgamento do irmão, que esfaqueara Dom Michele, ao ser pego com a boca na botija, durante o desembarque do contrabando. Depois de ter suas virtudes desmentidas no tribunal perante toda a comunidade, Lia percebe que não cabe mais na aldeia, e, por conta própria, decreta a própria penitência, abandonando a família.

— Quero ir embora! não quero ficar mais aqui! e falava isso à cômoda e às cadeiras, como uma louca, que em vão a irmã ia atrás dela chorando: - Eu Ihe tinha dito! eu Ihe tinha dito! e tentava agarrá-la novamente pelas mãos. De noite, quando trouxeram o avô na carroça e a Mena fora correndo encontrá-lo, sem ter mais vergonha dos outros, a Lia saiu no quintal e dali para a rua, e foi-se embora de fato, e ninguém tornou a vê-la. (p. 306)

${ }^{181}$ A coroa de rosas na cabeça é o emblema de Santa Rosalia. 
A taverneira Santuzza, ao saber o destino de Lia, agradece a "Nossa Senhora que a protegera do perigo em que caíra a irmã da Santa Ágata, como tantas outras" ${ }^{182}$. Na sociedade sem perspectivas, os papéis sociais femininos estão estagnados, e a rigidez dos costumes não abre brechas para mudanças. $\mathrm{Na}$ representação metonímica da estrutura social de Trezza, as três mulheres da casa da nespereira simbolizam as condições da existência feminina, no momento histórico contemporâneo. Resignar-se com a própria desdita é o que resta a Lia, assim como tinha acontecido à mãe e à irmã, que renunciaram aos desejos próprios, em favor do bem da família - tal qual a legenda, que narra as tentações das santas, nas provações da sua fé.

Para "uma boa dona-de-casa", como a Maruzza, mulher do Bastianazzo, um condenado como São Sebastião, e mãe de todos aqueles mártires e penitentes (Santo Antonio, São Lucas, Santa Ágata, Santo Aleixo e Santa Rosalia), só resta o destino de "mater dolorosa"183. Todos no povoado a chamam assim. A imagem da personagem é marcada, conforme sugere o seu hipocorístico, pela história de Maria, mãe de Deus. No decorrer do romance, a cada revés do seu destino, a Maruzza é denominada por algum epíteto tradicionalmente atribuído à santa. Todas as desgraças dos familiares recaem sobre seus ombros, conformando a sua imagem - logo que fica viúva, e está "sentada aos pés da cama, pálida e desfeita como um trapo sujo", tem a feição de "Nossa Senhora das Dores"; ou ainda, quando reza pela alma do filho Luca, morto em combate, sente "cravadas no próprio coração todas aquelas espadas de prata fincadas no peito da Virgem"184.

De natureza diferente, mas com a mesma marca de fechamento e perpetuidade, a função social do homem é determinada pelo dever e a obrigação. "Quem tem casa pra sustentar não tem querer deitar", diz o patrão 'Ntoni. O último parágrafo do prólogo sintetiza o papel masculino nessa comunidade: cuidar dos negócios e não abandonar o comando. No rigor da sociedade patriarcal, cabe-lhe ainda a tarefa de preservar e transmitir, "de pai

\footnotetext{
182 Os Malavoglia, p. 316 (grifo nosso).

183 Idem, p. 160.

${ }^{184}$ Idem.
} 
para filho"185, o legado da experiência e do conhecimento acumulado. Tal como faz o patrão 'Ntoni, ao repetir no dia-a-dia os provérbios e "outras sentenças judiciosas" dos antigos.

[...] "e o avô tratava de repetir: "Mar branco, siroco em campo" ou "mar crespo, vento fresco", como se estivessem ali para aprender provérbios; e com os benditos provérbios, enquanto ficava à noite olhando o tempo pela janela, de nariz no ar, ainda dizia: "Quando a lua está vermelha é sinal de vento, quando está clara faz tempo ameno; quando está pálida, vai chover." (p. 178)

É interessante observar como a legenda determina o modelo de representação de avô e neto nos seus papéis de depositários e transmissores da tradição familiar. O "patrão "Ntoni" e o "Ntoni do patrão 'Ntoni" são associados a Santo Antonio, cuja tradição também se desdobra num duplo: o precursor, Santo Antonio do deserto ${ }^{186}$ (III d.C.); e o seu seguidor, Santo Antonio de Pádua, que viveu quase um milênio depois, e adotou o nome em sua homenagem. Ambos foram pregadores bem-afamados, que, em seus discursos e sermões, reuniam milhares de ouvintes - caracterizam-se como velhos mestres da arte narrar baseada no princípio da sabedoria. As personagens romanescas são marcadas pelo atributo substancial dos santos: na história da família e de Trezza, tanto o avô quanto o neto cumprem funções sociais de narradores; na organicidade estrutural do romance, eles atuam como instâncias narrativas internas.

Contudo cabe ressaltar que, na construção das imagens de avô e neto a partir da recuperação das legendas de prógono e epígono, a articulação dos dois duplos desenvolve categorias de tempo, que sustentam a noção de sucessividade das gerações - critério essencial para a definição do tipo de narrador que cada personagem representa. Nesse caso, a regra de "dois pesos e duas medidas" mostra-se válida, pois o avô e o neto, como instâncias narrativas internas, defendem valores de conotações opostas, e, conseqüentemente, desempenham funções distintas.

\footnotetext{
185 Os Malavoglia, p. 13.

${ }^{186}$ Também conhecido como S. Antonio egípcio, ou S. Antonio Abade.
} 
Todos esses aspectos estão relacionados com o arquétipo da passagem do clã ${ }^{187}$, de acordo com o qual, o avô remete à figura do demiurgo, por ser o detentor da história da família e da sabedoria dos ancestrais, acumulada nos "motes e provérbios que ouvira dos antigos." O princípio organizador da passagem da tradição familiar determina que o filho seria o seu sucessor natural. Todavia, com a morte do Bastianazzo, cabe ao neto primogênito, o 'Ntoni, assumir tal posto, para dar continuidade à tradição e transmissão da história da família. O fim trágico do pai rompe a linha natural dos acontecimentos, e a tradição é subvertida pela precipitação das etapas de superação do ente mais velho pelo mais novo.

Caso o Bastianazzo, que "não teria assoado o nariz sem que o pai the tivesse dito 'assoe o nariz'", herdasse a função de narrador do patrão 'Ntoni, a tendência seria dar prosseguimento aos princípios e valores em vigor, sem grandes modificações. É o que sugere a passagem em que o pai examina a carta que o filho mandou de Nápoles, reclamando da má vida na Marinha:

O Bastianazzo abanava a cabeça e fazia que não, que assim não estava certo, e, tivesse sido com ele, teria colocado sempre coisas alegres, de fazer os outros rirem do fundo do coração, ali no papel, - e apontava para ele com o dedo grosso como a régua do escalmo [...]

A confluência desses aspectos no entrecho narrativo sinaliza o embate que se trava entre o conservadorismo do avô e o inconformismo do neto; pois, de acordo com a categorização arquetípica do esquema representado, o 'Ntoni, em seu tempo próprio, desempenha o papel de jovem órfão, que não se enquadra nas "molduras e cláusulas sociais" ${ }^{188}$ da comunidade patriarcal onde nasceu.

$\mathrm{Na}$ configuração das duas personagens como instâncias narrativas internas com funções distintas, o rompimento da linha sucessória familiar simboliza a ramificação da raiz comum, que deu origem a diferentes linhagens

${ }^{187}$ Cf. E. Meletínski, em Os arquétipos literários , pp. 42-45.

${ }^{188}$ Idem, p. 45. 
de narradores. O avô é emblema do velho mundo e reprodutor das convenções antiquadas, e o neto é porta-voz da nova ordem e das convicções reformadoras. Essa relação, estabelecida pela oposição dos atributos intrínsecos de cada um, é deslindada, no romance, como argumento da própria história. É o que pode ser observado no trecho em que os dois discutem sobre a vida que a família leva, e o discurso ("as palavras") de cada um exprime conceitos e ideais de vida diametralmente opostos:

- Sim, sim, alguma coisa você tem na cabeça, meu rapaz! Alguma coisa que antes não tinha. "Dize-me com quem andas, dirte-ei quem és".

- É que eu não passo de um pobre diabo! é só isso!

- Bem! que novidade! e não sabia disso? Você é o que o seu pai foi e o que foi o seu avô! "Quem mais quer, menos tem". "É melhor se contentar do que se lamentar".

- Grande consolo!

Dessa vez o velho encontrou logo as palavras, porque the vinham do coração:

- Ao menos, não diga isso diante da sua mãe.

- A minha mãe... Era melhor que não me tivesse parido, a minha mãe.

- Sim, acenava o patrão "Ntoni, sim, melhor que não o tivesse parido, se agora era para você falar deste jeito."

O 'Ntoni, por um instante, não soube o que dizer: - Pois bem! exclamou depois, o que vou fazer é por ela, pelo senhor e por todos. Quero enriquecer a minha mãe! é isso que eu quero. Agora suamos a camisa pela casa e pelo dote da Mena; daí, a Lia crescerá e, por menos ruins que sejam os anos, estaremos sempre na miséria. Não quero mais esta vida. Quero mudar a minha situação e a de todos vocês. Quero que sejamos ricos, a mamãe, o senhor, a Mena, o Alessi e todos.

O patrão 'Ntoni esbugalhou os olhos e ficou ruminando aquelas palavras, como que para poder engoli-las. - Ricos! dizia, ricos! e o que faremos quando ficarmos ricos? 
O 'Ntoni coçou a cabeça e pôs-se a procurar ele também o que fariam. - Faremos o que outros fazem... Não faremos nada, não faremos nada!... Iremos viver na cidade, sem fazer nada, e comer massa e carne todos os dias.

- Vá, vá você viver na cidade. Por mim, quero morrer onde nasci; - e pensando na casa onde tinha nascido, e que não era mais sua, deixou pender a cabeça sobre o peito. - Você é moço, e não entende isso!... não entende!... Vai entender o que é, quando não puder mais dormir na própria cama; e o sol não entrar mais pela sua janela!... Você vai entender! Digo-Ihe eu, que sou velho! - O pobre coitado tossia que parecia sufocar, com as costas curvadas, e abanava tristemente a cabeça: - "Minha casa, minha brasa". Está vendo aqueles pássaros? está vendo? Sempre fizeram o ninho ali, e tornarão a fazê-lo, e de lá não querem sair.

- Eu não sou um pássaro. Eu não sou um animal, como eles! respondia o 'Ntoni. Eu não quero viver como um cão preso à corrente, como o burro do compadre Alfio, ou como um jerico de nora, sempre girando a roda; eu não quero morrer de fome num cantinho, ou acabar na goela dos tubarões. (p. 218-19)

O jovem se recusa a dar continuidade à tradição, porque conhece "o mundo melhor que os outros" e sente-se entediado com os falatórios do avô. O seu comportamento, em correspondência à demanda dos novos tempos, associa-se a um tipo de narrador que se interessa por lugares distantes e anseia adquirir novos conhecimentos, para narrar experiências diferentes, com palavras novas.

- História boa, disse então o 'Ntoni, é a dos forasteiros que chegaram hoje, com uns lenços de seda que até parece mentira; e nem olham para o dinheiro que tiram do bolso. Correram meio mundo, diz, que Trezza e Aci Castello juntos não são nada em comparação.

(pp. 213-14) 
O avô, por sua vez, representa um tipo de narrador que se apega ao conhecimento do passado da sua terra, e, na época de transição em que vive, está condenado ao desaparecimento, porque a sua narração, sustentada pelos motes dos antepassados, não corresponde à realidade atual.

O patrão 'Ntoni, agora, tinha-se tornado uma perfeita ave de cemitério e outra coisa não fazia a não ser andar por ali, dobrado em dois, com aquela cara de cachimbo, a dizer provérbios sem pés nem cabeça (...) dele ninguém queria saber, agora que estava reduzido àquele estado. (p. 307)

A sociedade da remota aldeia de Trezza, regida por costumes e códigos arcaicos, fica à margem do desenvolvimento característico do final do XIX, não acompanha a evolução do pensamento e da tecnologia - sintoma de um mundo em desagregação, que não pode mais ser entendido com base na sabedoria popular acumulada, expressa pelos provérbios e aforismos. Tal dicotomia, que o abismo dos tempos acarreta, é flagrada, por exemplo, na passagem do romance, em que um grupo da velha guarda do vilarejo tem a sua conversa rotineira interrompida abruptamente:

Nesse instante, ouviu-se o apito da locomotiva e os vagões desembocaram de supetão na encosta do morro, vindos do buraco que tinham feito ali, fumegando e estrondeando como se tivesse o diabo no corpo. - Aí está! concluiu o patrão Fortunato: a ferrovia de um lado e os vapores do outro. Em Trezza já não se pode mais viver, palavra de honra! (p. 112)

A história de vida do 'Ntoni é marcada justamente pela impossibilidade de narrar esse mundo em transformação. A menos que se revolucione o modelo tradicional de narração...

Por isso é que a casa da nespereira prosperava, e o patrão 'Ntoni passava por pessoa com a cabeça no lugar, a ponto de que em Trezza tê-lo-iam nomeado conselheiro municipal, não fosse dom Silvestro, o secretário, ter apregoado do alto de sua experiência que 
era um caturra empedernido, um reacionário daqueles que defendem os Bourbons, e que conspirava pelo retorno de Franceschello, para poder mandar e desmandar no vilarejo, como costumava fazer em sua própria casa.

O patrão 'Ntoni, ao contrário, não conhecia Franceschello nem sequer de vista, cuidava de seus negócios, e costumava dizer: "Quem tem casa pra sustentar não tem querer deitar" porque "quem tem mando não abandona o comando." (p. 15)

A primeira frase do último estrato narrativo do prólogo sugere que o segredo da prosperidade da casa da nespereira (tal como é retratada no prólogo) encontra-se no passado idealizado, e na constante evocação de suas fórmulas consagradas. No entanto, ao se ler todo o período, percebe-se que, no quadro representativo da atualidade contemporânea, a afirmação inicial não se sustenta, uma vez que a "cabeça no lugar" do patrão 'Ntoni não serve para ocupar o cargo público do município. Isso demonstra que o ideal da política dominante despreza os valores axiológicos do passado, os quais, na prática, definem o modo de vida da população. Essa, em compensação, guiada pelo instinto de preservação da comunidade, tende a resgatar, nas situações corriqueiras do dia-a-dia, os índices das tradições culturais e históricas da terra de Trezza, numa tentativa de estabilizar as condições atuais da vida nesse universo social em transição.

Nessa última camada do prólogo são apresentados índices cronotópicos da vida cotidiana na praça pública. As referências aos cargos administrativos do município e nomes da casa bourbônica concentram informações significativas, que projetam quadros da situação sociopolítica da Itália recém-unificada. $O$ secretário, dom Silvestro é representante do regime administrativo da nova monarquia constitucional em Trezza; a alusão aos Bourbons aponta para o final do longo domínio bourbônico na Sicília; e a suposição de uma conspiração pelo retorno de Franceschello presume forças de resistência política ao Estado unificado.

O apelido popular Franceschello, atribuído a Francesco II de Bourbon, pela conotação depreciativa e jocosa, compõe uma caricatura do último soberano do Reino das Duas Sicílias. A alcunha diminui a figura do rei, 
reduzindo-o a mero fantoche, e destituindo o seu título de qualquer atributo de magnanimidade - em razão da circunstância em que se deu a sua renúncia, a qual teve início com a batida em retirada do campo de batalha, deixando Nápoles livre para as tropas garibaldinas, e culminou com sua evasão definitiva da Sicília. Como resume dom Silvestro, ao alfinetar os membros do conselho municipal de Trezza: "Tudo um bando de bourbônicos da mesma igrejinha; uns covardes, que hoje dizem branco e amanhã preto, e o último a falar tem sempre razão"189.

Para os indivíduos dessa comunidade, o elemento cômico é a chave que possibilita a leitura da realidade política italiana contemporânea. Em sua concepção crítica, a queda do velho regime bourbônico e a figura do rei deposto acabam virando motivos de chacota em conversas e comentários do dia-a-dia; dando margem à criação de pilhérias, anedotas, chistes e frases feitas sobre o tema, que se caracterizam como breves representações satíricas do episódio político. A ridicularização do acontecimento histórico e a zombaria do povo fazem parte de um processo de extravasamento, que, através do riso, procura restabelecer a ordem do mundo, uma vez que o sistema axiológico da sociedade foi transgredido pelo seu mais expressivo representante, o rei. De acordo com os valores arraigados de Trezza, a expatriação é um ato inaceitável, configura-se como uma ofensa à moral e aos bons costumes. É o que se depreende dos argumentos a que o avô e a Mena apelam, quando o 'Ntoni desabafa que quer ir para a cidade grande:

— Pois agradeça a Deus, se o fez nascer aqui; e nem pense você em ir morrer longe das pedras que o conhecem. (p. 219)

- O pior é expatriar-se de sua terra natal, disse a Mena, onde até as pedras o conhecem, e deve ser coisa de partir o coração deixá-las atrás de si pelo caminho. "Feliz do passarinho que em sua terra faz o ninho."

- Muito bem, Santa Ágata! concluiu o avô. Isto se chama falar com juízo. (p. 216)

${ }^{189}$ Os Malavoglia, p.118. 
Como fórmula concentrada do prólogo, que aponta para o esquema de representações do romance, o apelido burlesco do rei, em virtude de sua remissão a conteúdos do campo sociopolítico, estabelece a comicidade como chave de apreensão e tratamento da vida social nos espaços públicos de Trezza.

$\mathrm{Na}$ organicidade microestrutural do romance, a representação de cenas do cotidiano da vida pública dispõe as séries culturais pertinentes à dinâmica social do povoado - usos e costumes, códigos de valores e comportamentos, modos de tratamento, jargões e hábitos da profissão e da lida doméstica. Os moradores, regulados pela vida monótona, freqüentam sempre os mesmos lugares e caminhos. Todos vão à praça, e à missa de domingo; as mulheres encontram-se no lavadouro, na fonte, ou na praia à espera dos homens que estão no mar; os homens divertem-se na taverna da Santuzza, bebem a "erbabianca" na barbearia do Pizzuto, "fazem a república" na botica do dom Franco, e tratam negócios à sombra do olmo ou na escadaria da igreja. A abrangência da vida em comum faz da aldeia toda uma enorme praça pública, onde tudo acontece, e até o cego do tio Santoro vê. Não há privacidade, a não ser que a família se feche em casa, como manda o figurino, nos casos de doença, falência, vergonha ou luto. É o que acontece, por exemplo, depois que o 'Ntoni é preso, por esfaquear dom Michele. O avô diz:

- Não posso voltar à barca, enquanto o 'Ntoni estiver preso; não posso voltar. Todos nos olhariam onde passamos, e depois já não tenho a cabeça no lugar, agora que o 'Ntoni está preso.

E tornava a repetir sempre a mesma coisa, enquanto o dinheiro escoava como água e todos os seus passavam os dias recolhidos em casa, com a porta fechada. (pp. 300-01)

Como se tudo isso não bastasse, há toda sorte de bisbilhoteiros, que espiam detrás das moitas, escutam atrás das portas, e espalham as fofocas para quem quiser ouvir. Os assuntos particulares tornam-se de domínio público.

Porém, o compadre Tino sabia porque dom Michele estava indo zelar pelos interesses dos homens de bem lá para os lados da 
taverna, pois tinha perdido noites ficando de tocaia atrás do olmo ali perto para descobrir; e costumava dizer:

- Vai lá para confabular às escondidas com o tio Santoro, pai da Santuzza. Os que comem o pão do rei devem ser todos esbirros e saber da vida de cada um em Trezza e em toda a parte, e o tio Santoro, cego como ele é, que parece um morcego ao sol, à porta da taverna, sabe tudo o que se passa na aldeia, e poderia chamar um a um pelo nome só de ouvi-los andar. Ele só não escuta quando o feitor Filippo vai rezar o terço com a Santuzza, e é um verdadeiro achado para ficar de guarda, melhor do que se the tivessem vendado os olhos.

(pp. 43-4)

Todos esses aspectos, lugares e situações são partes da representação da vida diária na praça pública de Trezza, e recuperam elementos do teatro popular de marionetes, comédias do folclore e fábulas sicilianas ${ }^{190}$. O lavadouro, por exemplo, um lugar tradicional da narrativa popular, é resgatado nas narrações das mulheres, no cotidiano do trabalho. Na história que a prima Anna conta para as crianças, o lavadouro é o lugar "encantado" do encontro amoroso:

— Quem deve comer estas sardinhas aqui, começava a prima Anna, há de ser o filho de um rei coroado, lindo como o sol, que cavalgará um ano, um mês e um dia, no seu cavalo branco, até chegar a uma fonte encantada de leite e mel; onde, apeando do cavalo para beber, encontrará o dedal da minha filha Mara, que as fadas levarão, depois que a Mara o tiver deixado cair na fonte ao encher a bilha; e o filho do rei, ao beber no dedal da Mara, ficará apaixonado por ela; e cavalgará mais um ano, um mês e um dia, até chegar a Trezza, e o cavalo branco o levará ao lavadouro, onde minha filha Mara estará estendendo a roupa; e o filho do rei se casará com ela, pondo-lhe o anel no dedo; e depois fará com que monte na garupa do seu cavalo branco e a levará para o seu reino. (p. 215) 
As máscaras da cultura narrativa popular talham as imagens das personagens da vida pública. O prefeito do vilarejo, o mestre Croce Callà, é apelidado por todos de Giufà, porque tem a mesma aparência, os trejeitos e as expressões da personagem popular, que, em sátiras folclóricas e histórias para crianças, desempenha o papel de bobo.

Estava ali ainda o prefeito, mestre Croce Callà, o "Bicho da Seda", também chamado Giufà, com o secretário dom Silvestro, e como sempre de nariz para cima, tanto que o povo dizia que ele vivia farejando o vento para saber para que lado devia se virar, e olhava ora um ora outro que falava, como se estivesse procurando as folhas da amoreira e quisesse comer as palavras, e quando via o secretário rir, ele também ria. (p. 61)

O usurário da aldeia, o tio Crocifisso, é chamado de Campana di Legno (Sino de Madeira, literalmente), "porque fazia ouvidos de mercador quando queriam pagá-lo com conversa fiada"191. A rua é o seu local de trabalho, onde fecha os seus negócios, numa rotina infalível, conhecida por todos:

Ele era um bom diabo, e vivia de empréstimos aos amigos, não tinha outro ofício, e para isso passava o dia inteiro na praça, de mãos nos bolsos, ou encostado na parede da igreja, com seu casacão todo puído, pelo qual não dariam um tostão furado; mas tinha todo o dinheiro que quisessem e, se alguém vinha lhe pedir doze tarí, emprestava-os no ato, sob empenho, pois "quem faz crédito sem empenho, perde o amigo, a mercadoria e o engenho" [...] (p. 57)

Nos mexericos do dia-a-dia, os gestos e atitudes invariáveis da personagem são motivos de gozação; por isso, o tio Crocifisso costuma ser comparado com o "Peppinino" e o "Tartaglia" — o primeiro é personagem do

\footnotetext{
${ }^{190}$ Cf. V. Propp, em Comicidade e riso, cit., pp. 99-102.

${ }^{191}$ Os Malavoglia, p. 57.
} 
teatro de bonecos siciliano, e o segundo, máscara napolitana da Commedia dell'arte.

A praça pública é palco dos encontros, tratativas e negociatas que tramam os caminhos do enredo. As representações desses episódios, se considerados isoladamente, configuram-se como encenações que desenrolam motivos tradicionais da literatura humorística. O negócio dos tremoços estragados, por exemplo, desenvolve uma ação bastante explorada em peças da Commedia dell'arte e comédias clássicas da Europa Ocidental: "o fazer alguém de bobo"192. $\mathrm{Na}$ trama do episódio são observados componentes e procedimentos básicos, que sustentam a armação característica desse tipo de narrativa: a dupla de embusteiros, o tio Crocifisso e o Tino Piedipapera; a "vítima", o patrão 'Ntoni; o engodo, a venda a crédito dos tremoços estragados; o cenário, o local público.

O patrão 'Ntoni, então, para ir tocando o barco, tinha combinado com o tio Crocifisso, vulgo Campana di Legno, um negócio de tremoços comprados a crédito para vender em Riposto, onde o compadre Cinghialenta tinha dito que havia um navio de Trieste recebendo carga. Na verdade os tremoços estavam um pouco estragados; mas não havia outros em Trezza, e o ladino do Campana di Legno sabia muito bem que a Providência estava sendo carcomida inutilmente pelo sol e pela água, lá debaixo do lavadouro, sem serventia nenhuma; por isso insistia em dar uma de joão-sembraço. - Então, não está interessado? Não pegue! Mas um centavo a menos é impossível, em sã consciência! que minh'alma hei de entregá-la a Deus! - e balançava a cabeça, que realmente parecia um sino sem badalo. Essa conversa acontecia às portas da igreja de Ognina, no primeiro domingo de setembro, que fora festa de Nossa Senhora, com grande afluência de todos os povoados vizinhos; e também lá estava o compadre Agostino Piedipapera, que, com suas pilhérias, conseguiu fazê-los chegar a um acordo sobre as duas onças e dez a salma, a serem pagas "com o violino" a tanto por mês. (pp. 22-3)

${ }^{192}$ Cf. V. Propp, em Comicidade e riso, p. 100. 
Todas as etapas de realização do golpe aplicado no patrão 'Ntoni, assim como outros tantos ardis e logros que a narrativa desenvolve, acontecem a céu aberto; de tal modo que, ao ler tais passagens, o leitor tem a impressão de que os lugares públicos do vilarejo, como a praça, o areal, a taverna, a barbearia ou a porta da igreja são palcos em que as personagens caricatas encenam esquetes cômicos do cotidiano.

O local público pode também contar, ainda em moldes cômicos, um pouco da história contemporânea do país, como no caso específico da botica de dom Franco, que, nesse povoado esquecido, funciona como uma janela para o mundo, pois é aonde os jornais chegam, e os homens vão saber as notícias e discutir suas idéias. As personagens que a freqüentam reconstituem, metonimicamente, as frentes atuantes na cena política do Estado italiano recém-unificado: o secretário dom Silvestro representa a situação; o boticário dom Franco, a oposição de ideal republicano; o vigário dom Giammaria, o clero, não-simpatizante com o governo saboiano; e dom Michele, a segurança pública.

O boticário estava conversando à porta do estabelecimento, ao ar livre, com o vigário e alguém mais. [...] passavam o dia inteiro em discussões [...] e chegavam a ter derrames de bílis; mas não teriam conseguido passar um dia sem se verem. [...] e de vez em quando vinha dom Michele, primeiro-sargento da guarda-fiscal aduaneira; e também dom Silvestro, o secretário municipal, voltando do vinhedo, ali parava um momento.

Então, esfregando as mãos, dom Franco dizia que estava parecendo um Parlamento em miniatura, e ia plantar-se atrás do balcão, cofiando a barbona com os dedos, com um sorriso malicioso que parecia querer jantar alguém, e de vez em quando deixava escapar meias palavras em voz baixa diante da assistência, [...] tanto que dom Giammaria não o tolerava e roía o próprio fígado, atirando-Ihe na cara palavras em latim. Dom Silvestro, por sua vez, divertia-se ao vê-los com o sangue a ferver nas veias por dá cá aquela palha, sem ganharem um tostão com isso" [...] (pp. 30-1) 
Os "pilares" da sociedade de Trezza formam um verdadeiro elenco de bufões; seus discursos ideológicos, representativos do segmento privilegiado, são entretecidos na narrativa, simulando uma ópera-bufa, que satiriza a situação contemporânea da política nacional. Nessa camada narrativa encontrase a chave que decifra o universo social de Trezza; a caricatura dos fenômenos sociopolíticos da realidade italiana (Trezza, Sicília, Itália) põe a nu os defeitos, vícios e contradições do sistema social da época.

A carnavalização dos gêneros literários da Antiguidade e das tradições culturais de todos os tempos, concentrada no prólogo, e desenvolvida ao longo do romance, é um modo de atribuir dignidade literária à insignificante aldeia de pescadores da província siciliana; auferindo, de antemão, uma aura de grandiosidade e elevação a um objeto de representação que, convencionalmente, não tem valor artístico ou representatividade social. As raízes fincadas no solo antigo, da epopéia e da tragédia, validam o caráter de literaturidade da obra verista, conferindo tratamento literário sério ao argumento, à língua e às personagens, aparentemente deslocados da tradição. Do ponto de vista antropológico, a intertextualidade que o romance estabelece com tradições narrativas e gêneros literários de outros tempos é um modo de resgatar criticamente as origens do universo social representado, pela recuperação da herança sócio-artístico-cultural dos povos que colonizaram a região da Catânia e contribuíram na sua formação sociocultural. De acordo com tais aspectos, o apelo do romance aos gêneros literários consagrados não é, como supõe um dos estudiosos de Verga, um "ato de sublime anarquia cultural" ou de "diletantismo decadente" ${ }^{193}$ do autor; mas, antes, a refração de sua intencionalidade, ao explorar e tornar objetos de representação, os conteúdos intrínsecos ao próprio argumento do romance.

O prólogo, como estilização paródica de seu modelo clássico, em parte acata as convenções do gênero, e em parte, subverte-as. A simulação do estilo grandiloqüente e do discurso altissonante, a recitação genealógica e a invocação das tradições dos antepassados, a enumeração dos "heróis" (personagens principais) são procedimentos que estão de acordo com as normas do gênero. No entanto, no que diz respeito à organicidade e progressão

${ }^{193}$ Cf. N. Merola, em Giovanni Verga, p. 73. 
de seus conteúdos, a composição transgride a recomendação da retórica clássica, pois distingue-se pela marca do declínio. A grandiosidade inicial do texto não evolui para a tradicional chave-de-ouro, em que os elementos representados culminariam na elevação suprema. Em vez disso, o final do prólogo descarta toda e qualquer pomposidade, em favor do rebaixamento cômico.

De um lado, o desenvolvimento decrescente desse estrato narrativo, que tem início no passado glorioso, e termina na atualidade pouco plausível e até mesmo ridícula, configura-se como um artifício do narrador verista, para viabilizar a narração desse universo social que passa por mudanças profundas, e não pode mais ser narrado nos moldes convencionais da tradição literária. De outro, tal procedimento, ao dar mostras do desgaste dos tempos, explicita o rebaixamento do argumento literário; a narrativa da realidade contemporânea só é possível a partir da destituição dos atributos míticos dos elementos nela representados.

Todos esses aspectos que concorrem para a representação da decadência estão concentrados no simbolismo dos elementos do cronotopo inicial do romance, mais especificamente, nas "numerosas pedras da estrada velha de Trezza", que são minúsculos destroços dos enormes rochedos lançados pelos Ciclopes. O narrador verista ajusta as lentes para o mundo dos pequeninos, que não enxergam a grandeza lendária dos farilhões ciclópicos, mas tão-somente, o perigo que eles representam para o marujo que está no mar.

As referências mitológicas e lendárias articuladas na representação das personagens e dos episódios sustentam-se num fio tênue, reforçando a noção de que no mundo representado restam apenas os vestígios dos mitos e das lendas do passado. A operação paródica é a única maneira de presentificar a significação simbólica desses arquétipos, pois ela, a partir da projeção do plano da ancestralidade sobre o da atualidade, engendra estratégias de ruptura e revelação no esquema de representação, que dão chance ao desvendamento de significados surpreendentes, e provêem de sentido pleno os elementos do romance. Desse ponto de vista, a total inversão das expectativas, que o encaminhamento degressivo do prólogo provoca, leva ao rompimento da crosta 
narrativa, e à conseqüente exposição de significados mais profundos desse estrato, os quais desvelam uma sociedade sustentada pelas ruínas das civilizações anteriores.

Nesse sentido, percebe-se como a carnavalização de gêneros literários do solo antigo e modalidades narrativas da tradição popular faz com que os modelos cronológicos e axiológicos do passado sejam transferidos para a história contemporânea. Os traços constitutivos dessas tradições, transpostos para a narrativa moderna, atuam como agentes desencadeadores de um processo de cristalização que atinge em cheio as personagens e os eventos representados. Tal procedimento revela-se um poderoso recurso de que o narrador verista dispõe para mostrar o estado arqueológico de seu objeto, e dar ao leitor a sensação exata do processo de fossilização e soterramento, pelo qual passa a comunidade de Aci Trezza, que, em plena era do progresso, atémse a um sistema de vida regido por estruturas e costumes arcaicos.

Como procedimento do mecanismo de composição do romance, a transgressão de determinadas leis dos gêneros clássicos recuperados, cometida no prólogo, funciona também como carta marcada da trajetória do enredo, pois, no esquema do romance verista, a subversão estabelece-se como norma: os heróis são homens comuns, os grandes feitos são pequenos, as aventuras terminam mal, os deuses não protegem os humanos, não há salvação para os desafortunados, e a vida, uma vez desviada de seu curso, jamais retorna à normalidade.

Não existe a possibilidade de a história dos Malavoglia "da casa da nespereira e da Providência" terminar nas mesmas condições gloriosas da vida dos primeiros antepassados, tal como é descrita no estrato inicial do prólogo. Depois de todas as desgraças que desabaram sobre a família, e culminaram na entrega da casa e na venda da barca para o tio Crocifisso, o destino está selado.

Quando finalmente o Alessi resgata a casa da nespereira, simula-se a possibilidade da volta ao curso normal da vida, que, de fato, não ocorre, pois as condições já são outras. O Alessi simplesmente adapta o modelo de vida do avô ao contexto da atualidade. O padrão é retomado, mas a essência mudou. Tudo parece estar no seu devido lugar, pois lá estão "as galinhas no galinheiro e o 
bezerro no estábulo, a lenha e forragem no alpendre, as redes e toda sorte de apetrechos pendurados, tudo como dissera o patrão "Ntoni"194.

Mas... e a Providência? A barca não foi recuperada. O ícone da família partiu-se ao meio, virou ruína. Os Malavoglia não são mais "boa e brava gente do mar", como sempre foram; o elemento épico da biografia familiar esgotou-se, e não há como dar continuidade a essa mesma história.

Além disso tudo, há os "dois tresmalhados", o 'Ntoni e a Lia, que deviam estar "pelas estradas escaldantes de sol e brancas de pó" e "não voltariam mais à aldeia depois de tanto tempo" ${ }^{\text {"195; }}$ e também os espinhos cravados do avô, da mãe, do irmão e do pai, que partiram para nunca mais voltarem. Apesar do aparente restabelecimento da velha ordem, a vida dos Malavoglia que sobraram foi definitivamente marcada, e nem mesmo aqueles que voltam a morar na casa onde nasceram conseguem sossegar o coração:

Lembrando todas essas coisas, largavam a colher na tigela e pensavam e repensavam em todos os acontecimentos, que até parecia escurecer, como se acima de tudo pairasse a sombra da nespereira. (pp. 327-28)

A carnavalização do prólogo engendra outras peças importantes no mecanismo de composição do romance, como a construção da imagem da terra de Aci Trezza, e a apresentação dos componentes essenciais do seu sistema narrativo

A projeção de elementos do país dos ciclopes, da origem sícula, da civilização grega, dos dois impérios romanos, dos domínios normando, árabe e espanhol, e da monarquia constitucional de Vittorio Emanuele, combinam os traços e atributos que definem a máscara da terra de Aci Trezza, estabelecendo-a como personagem do romance. A recuperação de suas tradições expõe as especificidades que caracterizam a formação étnica e cultural do lugar - aspecto que, no desenvolvimento da história é confirmado, metonimicamente, pelos nomes e sobrenomes das personagens, os quais remontam às origens dos diversos povos que ali se estabeleceram: sículos

\footnotetext{
${ }^{194}$ Os Malavoglia, p. 326.

${ }^{195}$ Idem, p. 328.
} 
(Malavoglia, Zuppiddu, Cinghialenta, Mangiacarrube, Spatu); gregos (Sebastião, Filomena, Alessio, Luca); romanos (Antonio, Rosalia, Alfio, Venera); hebraicos (Maria, Anna, Michele); germanos (Franco, Betta). O esquema estrutural dos estratos, focos e instâncias narrativas do romance, articulado de acordo com a geografia da região, consubstancia a imagem de Trezza, como que the conferindo integridade orgânica. Essa imagem é construída com tamanha vivacidade, que, em determinadas passagens do romance, fica-se com a impressão de que a aldeia tem vida própria:

As colinas tinham tornado a se vestir de verde, e as figueirasda-Índia estavam novamente em flor. As moças tinham semeado manjericão à janela, e borboletas brancas vinham pousar ali; até as pobres giestas da sciara tinham suas pálidas florzinhas. De manhã, sobre os telhados, esfumeavam as telhas verdes e amarelas, e a passarada fazia algazarra até o pôr-do-sol.

Também a casa da nespereira parecia ter um ar de festa; o quintal estava varrido, os apetrechos bem arrumados ao longo da mureta e pendurados nas estacas, a horta toda verde de couves e de alfaces, e o quarto aberto e cheio de sol, parecendo todo contente também, e tudo dizia que a Páscoa se aproximava. Os velhos vinham para a porta lá pelo meio-dia, e as moças cantavam no lavadouro. As carretas voltavam a passar durante a noite, e ao anoitecer ouvia-se novamente o murmúrio de gente conversando na rua. (p. 141)

[...] a própria aldeia que ia adormecendo, ouvia-se o mar ressonar ali perto, no fim da ruela, e de vez em quando bufar, como quem se vira e revira na cama. (p. 44)

A recuperação carnavalesca dos gêneros da tradição literária e popular faz convergir produtivamente para o romance suas instâncias narrativas e respectivas linguagens. Desse modo, é sedimentada a base da construção do narrador verista, o qual se configura como uma instância narrativa superior, em terceira pessoa, produtora e organizadora de um sistema narrativo, que encadeia e articula as diversas instâncias internas. 
O narrador verista mimetiza as características constitutivas desses diferentes tipos de narradores, e, estilizando suas linguagens e esquemas discursivos, faz-se portador das vozes sociais e históricas estratificadas. Os componentes de suas tradições são urdidos no tecido narrativo do romance, pela representação paródico-estilizada dos mitos, arquétipos, símbolos, ícones e gestos recolhidos nas narrativas de todos os tempos - epopéia, tragédia e comédia gregas; romances de aventuras e provações; "commedia dell'arte"; legendas de santos e mártires; contos, sátiras e "causos" populares; anedotas; provérbios etc. A instância narrativa superior cria a voz de cada personagem e uma voz coletiva, da comunidade; e na composição da narrativa, faz com que soem livremente nas formas enunciativas do discurso (direto, indireto, indireto livre), num estilo contínuo, que as consolida num só bloco discursivo.

De acordo com esse sistema, a terra de Aci Trezza caracteriza-se como uma instância narrativa interna, à qual o narrador verista atribui essa voz coletiva, que reporta todas as linguagens e discursos dos diversos estratos sociais da aldeia.

Ao concertar todas as vozes sociológicas numa só voz da coletividade, o narrador as integra homogeneamente, sem, no entanto, deixar que percam suas características próprias; pois a instância narrativa coletiva expressa-se através de um discurso monolítico, que dispõe, em estratos sincrônicos, como num recorte arqueológico, os elementos intrínsecos ao repertório lingüísticocultural de cada segmento social representado. Essa instância distingue-se pelo caráter plurilíngüe do seu discurso, que carnavaliza diferentes linguagens sociais e discursos ideológicos.

A voz da coletividade parodia os atributos e funções do coro trágico, pois sua narração expressa o senso comum da população de Trezza, refletindo os valores e princípios morais em vigor na dinâmica social contemporânea. O coro é, a um só tempo, produto e produtor dessas vozes, e em suas narrações, manifesta-se ora em conjunto, ora em solos individuais, de coreutas. Ele narra determinados episódios e ações da trama, fazendo o relato de tudo aquilo que o povo vê, ouve, imagina ou fala.

Para que se verifiquem os traços constitutivos e a organicidade do discurso do coro; bem como, a atuação dessa instância no sistema narrativo do 
romance convém examinar determinados estratos do capítulo III, cuja narração concentra-se no dia em que os Malavoglia esperam pela volta do Bastianazzo, que partira com a barca para vender o carregamento de tremoços.

Depois da meia-noite o vento começara a fazer o diabo, como se no telhado estivessem todos os gatos do povoado, e a sacudir as persianas. Ouvia-se mugir o mar em torno dos farilhões, como se lá estivessem todos os bois da feira de Santo Alfio, e o dia despontara mais negro que a alma de Judas. Enfim, um horrível domingo de setembro, daquele setembro traiçoeiro que acerta na gente uma lambada de mar entre a cabeça e o pescoço, como um tiro de espingarda entre os figos-da-Índia. (p. 47)

Em concordância com uma das principais características da narrativa épica, as figuras predominantes nesse estrato são o símile e a comparação. As construções sintáticas das orações compostas são organizadas, quase sempre, de acordo com um padrão básico: à narração de um fato segue-se uma interpretação de senso comum, que o contextualiza ideologicamente. Desse modo, cada ação narrada é acompanhada de uma imagem, ou cena, que a retrata a partir de determinado ponto de vista ideológico, e dos elementos do seu respectivo repertório cultural, relativos às categorias sociológicas representadas. São as donas-de-casa que comparam o barulho do vento nos telhados e persianas, com o de "todos os gatos do povoado". Já os mais carolas associam o rumor do mar tempestuoso com aquele que fazem os "bois da feira de Santo Alfio"; e enxergam o dia "mais negro que a alma de Judas". Os marujos, por sua vez, sabem reconhecer o temporal típico do mês de setembro, que thes acerta uma lambada de mar entre a cabeça e o pescoço. E os contrabandistas relacionam o mar furioso com os tiros que os surpreendem, quando estão escondidos "entre os figos-da-Índia". E assim, as pequenas narrativas do cotidiano, que estão na boca do povo, convergem para a prosa romanesca, criando uma variedade de imagens de um mesmo fato ou episódio, que compõem um rico panorama dos aspectos da vida doméstica, religiosa, do trabalho, da praça pública. 
O repertório lingüístico diversificado, graças à incorporação dos temas e motivos culturais populares torna-se instrumento de representação realista desse universo social, pois a linguagem literária é criada a partir da estilização da língua falada da comunidade siciliana, com todas as suas particularidades lexicais, sintáticas, semânticas; o ritmo da oralidade é garantido pela reprodução sistemática de provérbios, epítetos, frases feitas, lugares-comuns e jargões do trabalho e da lida doméstica.

Essas fórmulas, que são recorrentes no romance e remetem à tradição narrativa homérica, contribuem para unificar o estilo, garantindo a unidade do discurso narrativo. $\mathrm{O}$ esquema frásico que as compõe é basicamente sempre 0 mesmo, o que muda são os nomes das personagens e os seus atributos referidos. Os epítetos, por exemplo, geralmente são frases curtas atreladas aos nomes de algumas personagens, e caracterizam-se como denominações sugestivas, explicativas ou pejorativas, que retratam um traço distintivo ou atitude habitual da personagem, que todos do povoado conhecem ou estão acostumados a ver: dessa forma são designados o "Ntoni do patrão 'Ntoni" e o "Menico da Locca"; o boticário dom Franco, que sempre se põe "a rir entre os fios da barbona"; o secretário dom Silvestro, ri "cacarejando feito galinha"; o guarda aduaneiro dom Michele, faz a ronda "de pistola na barriga e calças dentro das botas"; e a Nunziata, sempre está rodeada pelos irmãozinhos, parecendo "uma galinha choca com seus pintinhos"196. Esses excertos qualitativos, ao introduzirem apreciações das personagens através da voz do narrador, articulam diferentes planos de entoações, pois se constituem como discursos ocultos ${ }^{197}$, por meio dos quais o narrador expressa opinião de forma indireta, sem comprometer a impessoalidade do seu discurso.

O jogo narrativo do coro organiza, como na tragédia, manifestações conjuntas e individuais. Na passagem em que a Longa está aturdida, por causa do marido no mar com um temporal daquele, tem-se a impressão de que a voz de um coreuta se destaca:

\footnotetext{
${ }^{196}$ Os exemplos podem ser conferidos respectivamente em Os Malavoglia, pp. 16, 39, 43, 36-37.

${ }^{197}$ Cf. M. Bakhtin, em Marxismo e filosofia da linguagem, p. 169.
} 
Maruzza, a Longa, não dizia nada, como era o certo, mas não conseguia ficar quieta um instante, e não parava de andar de um lado para o outro, em casa e no quintal, parecendo uma galinha prestes a botar o ovo. (pp. 47-8)

Assim como quando é narrado o episódio em que o patrão 'Ntoni, desesperado, aguarda pela Providência:

À beira-mar estava somente o patrão 'Ntoni, por causa do carregamento de tremoços, que seguia mar adentro na Providência e, também, do seu filho Bastianazzo, além do filho da Locca, que nada tinha a perder, e no mar só tinha o irmão Menico, no barco dos tremoços. (p. 48)

O coro se manifesta em uníssono, para narrar fatos que dizem respeito a toda comunidade; ou então, um coreuta narra uma determinada ação, relacionada, geralmente, com uma só personagem, ou pequeno grupo. Nos dois casos, as narrativas expõem episódios que movimentam a trama, expressando observações do senso comum da aldeia; e, por meio de comparações e símiles, constroem imagens triviais desse universo social.

De acordo com o código de comportamento da comunidade, em situações e assuntos relacionados com o trabalho dos homens, a mulher não deve dizer nada. Então, segundo a opinião generalizada expressa pelo coro, à Maruzza só resta ficar "de um lado para o outro", tal e qual ficam as galinhas nos quintais da aldeia; e ainda, o velho 'Ntoni está à beira-mar ansioso por notícias, em primeiro lugar, dos tremoços; depois, do filho Bastianazzo.

É interessante observar como funciona o esquema dos narradores, na construção da narrativa, e na estruturação do enredo. Para ordenar a sucessão dos acontecimentos que compõem o episódio central do capítulo III, o naufrágio da Providência, o narrador verista organiza estratos narrativos, que expõem as manifestações do coro, e todas as conversas, fofocas e súplicas, relativas à barca, que "seguia mar adentro", com os tremoços, o Bastianazzo e o Menico da Locca. São selecionados determinados discursos para representar as cenas que encadeiam a progressão do episódio. O coro relata o temporal, e descreve 
a Longa, no quintal; o patrão 'Ntoni e o irmão do Menico, à beira mar; e toda a gente que está na "baiuca de sóror Mariangela, a Santuzza"198, onde só se fala do mesmo assunto. A certa altura, o Piedipapera comenta:

- O Bastianazzo Malavoglia está pior do que ele, a esta hora, respondeu o compadre Piedipapera, e o mestre Cirino pode badalar o sino da missa à vontade; mas os Malavoglia não vão à igreja hoje; estão de mal com o Dominus Vobiscum, por causa da carga de tremoços que têm no mar. (p. 49)

Pouco depois, à hora da missa, todos vão para a igreja. Lá, as mulheres não falam de outra coisa:

A Zuppidda, ali perto, debulhava ave-marias, sentada nos calcanhares, lançando olhares para um lado e outro, que parecia andasse às turras com a aldeia inteira, e a quem quisesse ouvi-la, repetia: - A comadre Longa não vem à missa, tendo o marido no mar com um temporal desse! Depois não adianta querer saber porque Deus castiga!

[...]

- É preciso rezar também pelos pecadores; respondia a Santuzza; as boas almas estão aqui para isso. (р. 50)

O coro, como portador da voz da comunidade, revela o pensamento comum:

Ninguém podia deixar de pensar que aquela água e aquele vento valiam ouro para os Cipolla; as coisas deste mundo caminham de tal modo, que os Cipolla, agora que tinham a chalupa bem amarrada, esfregavam as mãos assistindo à borrasca; enquanto os Malavoglia iam ficando brancos e arrancavam os cabelos, por causa da partida de tremoços que tinham tomado a crédito do tio Crocifisso Campana di Legno. (p. 51)

${ }^{198}$ Os Malavoglia, p. 48. 
O tio Crocifisso, que financiou a compra dos tremoços que estão no mar, reza ajoelhado

ao pé do altar de Nossa Senhora das Dores, de terço na mão, e entoava as estrofes com uma voz fanhosa, capaz de amolecer o coração do próprio satanás. Entre uma e outra ave-maria, falava-se do negócio dos tremoços, da Providência, que estava no mar, e da Longa, que ia ficar com cinco filhos nas costas. (p. 51-2)

Ao anoitecer, a Longa vai com os filhinhos para a sciara, avistar o mar, e eles até "pareciam as almas do Purgatório", dizem os que viram. Depois, quando a estão levando para casa, e passam em frente à porta da taverna, o tio Santo sentencia:

- Requiem eternam, rosnava em voz baixa o tio Santoro, o coitado do Bastianazzo sempre me dava esmola, quando o patrão 'Ntoni Ihe deixava uns trocados no bolso. (p. 54)

O melhor é que se trata da narração de um acontecimento que ninguém está vendo. A narrativa é constituída de especulações, previsões, suposições, as quais vão, progressivamente, consumando o fato, que culmina no "grito desesperado" da Longa.

Na frente da varanda de sua casa estava um grupo de vizinhas que a esperavam, tagarelando juntas em voz baixa. Assim que a viram de longe, a comadre Piedipapera e a prima Anna vieram ao seu encontro, com as mãos na barriga, sem falar nada. Então ela enterrou as unhas nos cabelos com um grito desesperado, e foi correndo fechar-se em casa.

- Que desgraça! diziam na rua. E o barco ia carregado! Mais de quarenta onças de tremoços! (p. 55) 
A narração da morte do Luca, que estava fora de casa, servindo a Marinha, segue o mesmo esquema. A ação é narrada através do discurso de dois marinheiros vindos de fora, que contam a história da batalha, em que o navio onde estava o Luca naufragou, bombardeado por uma esquadra inimiga.

No tal ajuntamento, [...] havia dois soldados da marinha, de saco às costas e as cabeças enfaixadas, que voltavam de licença. No entanto, tinham parado no barbeiro para cavar um traguinho de erbabianca. Contavam que se havia travado uma grande batalha no mar e que embarcações do tamanho de Aci Trezza, abarrotadas de soldados, tinham sido afundadas; em suma, um mundaréu de coisas que pareciam as que eram contadas na história de Orlando e dos paladinos de França na Marinha de Catânia, e as pessoas escutavam de orelhas em pé e paradas feito moscas.

- O filho da Maruzza, a Longa, também estava no Rei da Itália, observou Dom Silvestro, que se aproximara para ouvir.

\section{$[\ldots]$}

O soldado não parava de falar àqueles que Ihe davam ouvidos, gesticulando com os braços como um pregador. - Sim, havia lá sicilianos também; havia gente de todos os lugares. De resto, vocês sabem, quando toca a generala nas baterias, não se ouve mais nem sor nem senhor, e as carabinas fazem todos falar a mesma língua. Valentes rapazes todos eles! e com fígados sob a farda. Ouçam, quando se viu o que estes olhos viram, e como aqueles rapazes cumpriam o seu dever, Virgem Santa! podemos usar este quépi de lado, sim senhores!

O rapazola tinha os olhos brilhantes, mas dizia que não era nada, que era da bebida. - Chamava-se Rei da Itália, um navio sem igual, com uma couraça, que se podia dizer parecida com o espartilho que vocês, mulheres, usam e como se este espartilho fosse de ferro contra o qual se pudesse disparar um tiro de canhão sem causar dano. Foi a pique num segundo, e não mais o vimos, em meio à fumaça, uma fumaça que parecia sair de vinte fornos de olaria, sabem como é?

(pp. 154-55) 
A linguagem literária comporta os diferentes discursos sociológicos, por meio de um trabalho de estilização, em que o narrador verista preserva as especificidades de cada um, dispondo-os em estratos narrativos indissociáveis, que compõem organicamente a narrativa.

Dessa perspectiva, pode-se perceber que a isenção e a impessoalidade do narrador funcionam bem como normas reguladoras do seu método de composição; como resultado artístico, revertem em suprapessoalidade. $O$ segredo da impessoalidade do narrador de Os Malavoglia reside na sua excepcional parcialidade, que é, convencionalmente, projetada e subentendida como aquela própria do objeto; e também na habilidade de escamotear sua persona (como entidade ficcional), multidimensionando-a numa série de instâncias narrativas internas, que, por sua vez, parodiam tipos tradicionais de narradores. O narrador verista cria artisticamente o mundo narrativo, e, de acordo com o princípio metonímico de concepção do romance, configura-se como o criador de uma obra literária em que o narrador é a própria obra.

A instância narrativa superior projeta a história em diversos textos, estilizando todas as vozes do universo ficcional. Além do coro, que parodia os discursos ideológicos da comunidade, o narrador verista manipula duas instâncias narrativas fundamentais, representativas dos princípios sociais masculino e feminino. No universo social de Trezza, os homens têm voz, e cumprem o encargo de transmitir a tradição oral "de pai para filho"199; as mulheres, ao contrário, não devem dizer nada, "como era o certo"200, e passam, de mãe para filha, a tradição da tecelagem. Ser mulher em Trezza é "estar sempre ao tear"201.

A moça como é criada, a estopa como é fiada", disse por fim o patrão Malavoglia, e o patrão Cipolla confirmou que todos na aldeia sabiam que a Longa tinha sabido criar a filha, e que qualquer um que passasse pela ruela àquela hora, ouvindo as batidas do tear de

\footnotetext{
${ }^{199}$ Os Malavoglia, p. 13.

${ }^{200}$ Idem, p. 47.

${ }^{201}$ Idem, p. 15.
} 
Santa Ágata, diria que ela, a comadre Maruzza, não desperdiçava o óleo do candeeiro. (p. 32)

As funções narrativas masculinas e femininas são bem definidas; os homens representam a expressão verbal e os aspectos épicos da história; as mulheres, a expressão emotiva, e a visão fatalista. A narrativa é feita do relato racional dos homens e da urdidura emocional das mulheres; o trabalho das tecelãs desenvolve-se como esteio da função de narrador específica dos homens. As mulheres produzem a história bruta, configurando-se como protonarradoras de um discurso pré-lógico - para as mulheres de Trezza daquele tempo, a lógica da língua não é o instrumento de compreensão dos fatos da vida. Na sociedade patriarcal, as mulheres são marcadas pelo silêncio.

Desde que ouve falar pela primeira vez do negócio dos tremoços, a Longa tem um mau pressentimento, mas como não tem direito à voz, cala-se:

A Maruzza sentia sempre o coração pesado, mas não abria a boca porque não era assunto seu, e, bem quietinha, tratava de arrumar o barco e tudo o que era necessário para a viagem, o pão fresco, a bilha de azeite, as cebolas, o capote forrado de peles, embaixo do pau de voga ou no paiol de provisões. (р. 24)

$\mathrm{Na}$ quietude do trabalho diário, enquanto preparam o tecido, mãe e filha desfiam os sentimentos calados no peito, e as recordações dos entes queridos:

O compadre Bastianazzo não pôde assistir a esta festa! pensava com seus botões a comadre Maruzza, avançando e recuando diante da urdideira, preparando a trama, que aqueles rolos e aquelas travessas tinham sido todos feitos pelas mãos de seu marido, aos domingos ou nos dias de chuva, e fora ele mesmo que as pregara na parede. [...] A Mena, enquanto engomava o tecido, também estava com um aperto coração, pensando no compadre Alfio, que ia embora para Bicocca, e venderia o seu burro, pobre animal! (pp. 108-09) 
A trama das tecelãs é feita dos silêncios significativos; nela é urdido tudo aquilo que não é dito, mas, sentido, e pressentido. De acordo com essa forma particular de apreender o mundo, a narrativa das mulheres não pode ser lida, ou compreendida racionalmente; mas, percebida nas entrelinhas, e, desse modo, estabelece-se o substrato emotivo do sistema narrativo do romance. As tecelãs tramam, "ao vivo", intuições, emoções e afetos relacionados com a vida familiar.

Depois que o 'Ntoni vai embora de casa para o serviço militar, a Longa se consola no tear:

A mãe, enquanto rebatia o pente no tear — um! dois! três! pensava naquele bum bum da locomotiva que levara seu filho, e que Ihe ficara no coração, naquele grande atordoamento, e ainda batia em seu peito, — um! dois! três! (p. 19)

Os gostos e desgostos da vida são urdidos no próprio ato de tecer; no movimento das travessas cumpre-se um ritual de estruturação e condução do mundo. A Mena, sentada ao tear, dispõe os fios do seu destino:

A Mena ficava muitas vezes com um aperto no coração enquanto tecia, porque as moças têm faro fino, e agora que o avô andava sempre de confabulações com o compadre Fortunato, e em casa não parava de falar dos Cipolla, tinha sempre a mesma imagem diante dos olhos, como se aquele cristão do compadre Alfio estivesse colado nas travessas do tear, junto com os santinhos. (р. 130)

Assim como o patrão 'Ntoni e o 'Ntoni relacionam-se com as legendas dos santos pregadores homônimos; a Longa e a Mena estão ligadas à antiga tradição mediterrânea das tecelãs; e, na passagem da herança cultural feminina, cabe à jovem dar continuidade à urdidura da história afetiva da família. Esses aspectos são reforçados pela associação da personagem à Santa Ágata, patrona das tecelãs; e pelo significado de Filomena, 'amante do canto' (do grego), ou ainda, pela interpretação imaginativa, das duas palavras (em italiano), que se desprendem do nome: filo (fio) - mena (conduz, de "menare") 
- sugerindo a idéia daquela que conduz o fio da vida, ou tece a trama da história.

No trabalho cotidiano de mãe e filha, cumpre-se o ritual da transição:

A Mena, porém, estava tranqüila e, por conta própria, tornara a pôr a presilha de prata nas tranças, sem abrir a boca. [...] A mãe a mimava com os olhos, enquanto trabalhava ao seu lado, e a acariciava com o tom da voz, quando Ihe dizia, - passe-me a tesoura, ou, segure a meada - porque sentia a filha nas próprias entranhas, agora que todos the voltavam as costas; mas a moça cantava como um estorninho, porque tinha dezoito anos e, nessa idade, se o céu é azul, ele ri nos olhos da gente e os pássaros cantam no coração. Aliás, nunca tinha gostado daquela criatura, como disse no ouvido da mãe, enquanto urdiam a trama. A mãe era a única que tinha lido em seu coração e que soubera lhe dizer uma palavra boa naquela angústia. - Pelo menos, se o compadre Alfio andasse por aqui, não nos teria dado as costas. Mas quando for a época do vinho novo, ele há de voltar. (р. 167)

A representação desses aspectos e atributos da personagem carnavalizam o arquétipo literário das deusas gregas ao tear. A cena da Mena que tece, cantando "como um estorninho", remete a duas passagens da Odisséia, em que Calipso e Circe trabalham em condições muito semelhantes:

[...] dentro, cantava Calipso com bela voz e, indo e vindo junto ao tear, tecia com uma lançadeira de ouro.

[...]

Parados no vestíbulo da deusa de belas madeixas, ouviam a voz maviosa de Circe, que, dentro, cantava, indo e vindo tecer uma trama grande e imperecível como são os trabalhos finos, bonitos e brilhantes, das deusas. ${ }^{202}$

${ }^{202}$ Cf. Homero, Odisséia, pp. 61 e 118, respectivamente. 
A história da Mena, que anseia pela volta do Alfio Mosca, parodia o mito de Penélope, que espera pelo retorno de Ulisses, e, para protelar as propostas de casamento dos pretendentes, fez a promessa:

[...] e deixo fundir meu coração de saudades de Odisseu. Eles me pressionam para que me case e eu venho tecendo enganos; para começar um deus suscitou-me a idéia de instalar em meus aposentos um grande tear e pôr-me a tecer um pano delicado e demasiado longo, e daí lhes disse: Moços, pretendentes meus, visto como morreu o divino Odisseu, pacientai em vosso ardor pela minha mão até eu terminar a peça, para que não se desperdice o meu urdume: [...] Assim falei e os seus corações altivos deixaram-se persuadir. Daí, de dia, ia tecendo uma trama imensa: de noite, mandava acender as tochas e as desfazia. ${ }^{203}$

$\mathrm{Na}$ representação da personagem romanesca, evidencia-se a destituição do mito épico da fidelidade feminina, simbolizado pelo tear e o trabalho diário da urdidura. Penélope tece enquanto espera por Ulisses, e a Mena, pelo compadre Mosca; o desejo da rainha de Ítaca realiza-se integralmente, já o da Santa Ágata, não se cumpre. O compadre Alfio volta para Trezza, no entanto, encontra condições tão adversas em seu retorno, que em nada favorecem a conciliação dos enamorados.

Simbolicamente, o tear relaciona-se com a intuição, por isso as narradoras-tecelãs sabem ler o coração, e, ao sussurrarem palavras boas, de consolo, fiam o destino dos indivíduos. Tecer não é somente um ato de predestinação, é também criação; a reunião de realidades diversas no plano cosmológico $^{204}$. Toda a significação do trabalho das mulheres, como produtoras e produtos da trama, deslinda-se no entrecho da história. Logo depois da morte da Longa, a Mena pára de tecer, porque não Ihe sobra mais tempo:

[...] agora que the morrera a mãe e andava de lenço preto; e depois devia também cuidar da irmãzinha, servir-Ihe de mãe, sem ter quem

${ }^{203}$ Cf. Homero, Odisséia, p. 225. 
a ajudasse nos afazeres de casa, tanto que precisava ir até ao lavadouro e à fonte, e levar o pão aos homens, quando trabalhavam por diárias; de modo que já não era como a Santa Ágata, quando ninguém a via e não largava do tear. Agora tinha pouco tempo para tecer. (p. 239)

Durante o tempo em que a Mena fica afastada do tear, a vida da família parece escapar-Ihe às mãos: a Lia, espevitada, não lhe obedece; o 'Ntoni passa o dia "vadiando pela aldeia" ${ }^{205}$, e a noite, bebendo na taverna; o avô, doente, "passava a maior parte do tempo na cama, como um caranguejo debaixo das pedras". Ao deixar o tear, a Mena sela o próprio destino, e sossega definitivamente o coração, subindo para o sótão da casa da nespereira, como uma caçarola velha.

$\mathrm{Na}$ representação da história do amor da Mena e do Alfio Mosca, vê-se arruinado o ideal épico do regresso à terra natal. E o carroceiro se lamenta:

- Ah! Nunziata! quem diria, quando ficávamos conversando de uma porta à outra, a lua no céu, e as vizinhas a prosear ali em frente, e ouvia-se o dia inteiro o barulho do tear da Santa Ágata, e as galinhas que a conheciam só de puxar o ferrolho, e a Longa que a chamava pelo quintal, que dava para ouvir tudo de casa, como se eu estivesse lá dentro! Pobre Longa! Agora, veja, que tenho a mula e tudo que desejava, que se um anjo do céu tivesse vindo me anunciar eu não teria acreditado, agora, penso sempre naquelas noites, em que ouvia as vozes de todas vocês, enquanto cuidava do burro e via a luz na casa da nespereira, que agora está fechada, e quando voltei, não encontrei mais nada do que tinha deixado, e a comadre Mena não me pareceu mais a mesma. Quando a gente sai da sua terra é melhor não voltar mais.

[...] porque tudo muda de cara, enquanto estamos longe, e até as caras com que nos olham estão mudadas, e parece que também nós nos tornamos estrangeiros. (р. 310)

\footnotetext{
${ }^{204}$ Cf. Dictionnarie des symboles - mythes, réves, coutumes, gestes, formes, figures, couleurs, nombres.

${ }^{205}$ Os Malavoglia, p. 213.
} 
O patrão 'Ntoni e o 'Ntoni são instâncias narrativas internas fundamentais do romance, e parodiam dois tipos de narradores, descendentes dos antigos "narradores anônimos" ${ }^{206}$, cujas origens reportam a camponeses e homens do mar, velhos contadores populares de história. $\mathrm{Na}$ representação das personagens como narradores internos, eles cumprem funções narrativas diferenciadas, cada qual de acordo com a sua tradição. A primeira categoria refere-se ao narrador sedentário, que vive na terra natal, conhece o seu passado, e narra suas histórias e tradições; a segunda, ao narrador viajante (volante, andarilho), que porta histórias e tradições de todas as terras. As características do primeiro tipo correspondem à personagem do patrão 'Ntoni, que, embora seja homem do mar, é de natureza sedentária; pois o mar é tãosomente o seu local de trabalho. A sua aventura diária restringe-se ao perímetro da pescaria, e mesmo quando a sua barca afasta-se para longe, o velho não perde de vista a mancha branca das "casinhas de Trezza"207. O avô é o depositário da história da família, e, no interior do romance, sua função narrativa é referencial, extremamente econômica e objetivada, desempenhada na medida exata da sua incumbência de transmitir a tradição aos descendentes:

\section{O patrão 'Ntoni só fazia pensar na Providência, e quando não} tratava de seus assuntos, não falava nada, e participava da conversa como um cabo de vassoura. (p. 29)

Ele transmite o modo de vida e os princípios morais dos antepassados, através da própria conduta de apego aos costumes; e da ladainha diária, dos "motes e provérbios que ouvira dos antigos"208. Já os atributos do narrador viajante remetem ao neto "Ntoni, que serviu como soldado na marinha e aventurou-se em outras terras. O mar do "Ntoni, convida-o a "olhar para longe", onde ficam "aquelas cidades grandes" ${ }^{209}$; é o seu ponto de fuga, de onde vislumbra uma possibilidade de mudança. $\mathrm{Na}$ representação da história contemporânea, a ligação da personagem com essa categoria de narrador

\footnotetext{
${ }^{206}$ W. Benjamin, em "O narrador — observações acerca da Obra de Nicolai Leskow", p. 58.

207 Os Malavoglia, p. 176.

${ }^{208}$ Idem, p. 15.
} 
define o seu caráter inovador, que, na tentativa de apreender o mundo em transformação, leva-o a questionar as convenções, e querer revolucioná-las. E é para isso que ele, mesmo sem se dar conta, está sendo instruído: "É preciso

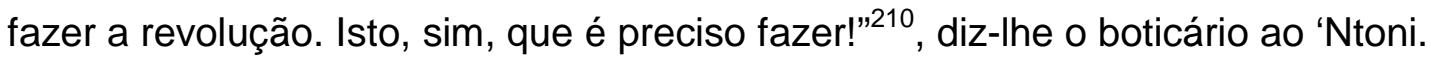

O Dom Franco, "mais escolado que os outros", é representante da voz ideológica revolucionária, porque sempre lê a gazeta e tem até "a História da Revolução francesa", além de ser "da seita"211, "protestante e judeu" ${ }^{212}$, como todo mundo na aldeia sabe. Depois que o rapaz volta do serviço militar, o boticário torna-se seu mentor, e o faz ler os jornais, pois, afinal de contas, "não é culpa dele se não sabe se expressar melhor, é culpa do governo que o deixa na ignorância" ${ }^{213}$. Ser discípulo de uma pessoa que não pertence à família confirma o rompimento da linha de transmissão "de pai para filho" da herança cultural. O 'Ntoni bebe em outras fontes, e entra em contato com uma série de elementos extraordinários, que ampliam o seu repertório narrativo. Desse modo, ele se distancia cada vez mais do ramerrão monocórdico da experiência e da história familiar, e alcança um raio de ação mais abrangente.

Assim, o 'Ntoni fazia sermões, como o boticário; pelo menos isso tinha aprendido na viagem e agora abrira os olhos, como os filhotes de gato depois de quarenta dias de nascidos. "A galinha que cisca volta para casa com o papo cheio". À falta de outra coisa ele tinha enchido o papo de juízo e andava contando o que aprendera na praça, no estabelecimento do Pizzuto e até na taverna da Santuzza. (p. 245)

Orgulhoso dos discursos do 'Ntoni, dom Franco gosta de repetir a quem quiser ouvir: "Esse rapaz aí tem talento!"; mas não deixa de arrematar: "Enxerga as coisas por atacado, meio atabalhoadamente, mas a essência está ali" ${ }^{214}$. A essência de um narrador que não cabe em sua terra.

\footnotetext{
${ }^{209}$ Idem, p. 220 (as duas citações).

210 Idem, p. 257.

211 Idem, p. 39.

212 Idem, p. 53.

213 Idem, p. 257.

${ }^{214}$ Idem (as duas citações).
} 
Nos tempos que correm, o patrão 'Ntoni, caracteriza-se como um narrador obsoleto, pois sua fonte é a sabedoria ultrapassada dos ancestrais; já o 'Ntoni estabelece conexão com o mundo moderno e tem sede de informações novas. Esses aspectos são determinantes na superação do velho pelo novo, e renovação do modelo tradicional de narração. "O lado épico da verdade, a sabedoria, está agonizando" ${ }^{215}$, e a arte de narrar só se renova pela orientação para o conhecimento de interesse prático da experiência atual.

A história da vida do 'Ntoni, seu aprendizado em casa, na barca, na Marinha, na botica, na taverna, na praça, na cadeia, e em outras terras é a história da formação de um narrador popular, descendente da velha linhagem do contador de histórias siciliano. Na organicidade do sistema narrativo, a personagem se estabelece como a instância interna principal, porque "conta a história que o romance conta". Quando o 'Ntoni volta à casa da nespereira, depois de tantos anos longe da terra natal, e olha para tudo, perguntando pelo avô e pela Lia, arremata a história dos Malavoglia do patrão 'Ntoni, "aqueles da casa da nespereira, e da Providência" ${ }^{\prime 16}$. Ele explica para o Alessi que antes "não sabia nada e não queria ficar", mas agora, que sabe de tudo, deve partir. No meio da estrada, senta-se "na mureta da vinha do feitor Filippo"217, e começa a plasmar a sua história:

E assim permaneceu durante um bom tempo, pensando em muitas coisas, olhando a aldeia escura, e ouvindo o mar que resmungava lá embaixo. E ali ficou até que começaram a ser ouvidos certos ruídos que ele conhecia, e vozes que se chamavam dentro de casa, e o bater das venezianas e passos pelas ruas escuras. À beiramar, no fundo da praça, começavam a formigar luzes. Ele levantou a cabeça para olhar os Três Reis que tremeluziam e a estrela dalva que anunciava o amanhecer, como tantas vezes tinha visto. Então, tornou a inclinar a cabeça sobre o peito e a pensar em toda a sua história.

\footnotetext{
${ }^{215}$ W. Benjamin, em "O narrador — observações acerca da Obra de Nicolai Leskow", p. 58. ${ }^{216}$ Os Malavoglia, p. 13.
} 
A história que o 'Ntoni rememora, no final do romance, é a que tem início no prólogo, quando o narrador verista convida o leitor a adentrar Aci Trezza pela mesma "estrada velha" ${ }^{218}$. O propósito desse narrador é reproduzir fielmente a narração popular, tal como é colhida nas ruas da província. Na produção do romance, ele estiliza a narrativa do 'Ntoni, o qual, de acordo com a sua experiência de viajante, parodia outros narradores, juntando cacos de narrações de todos os tempos, que ecoam pelas estradas; e as reinventa, imitando ora forma, ora conteúdo (ou ambos), como o recurso que tem ao seu alcance para criar um estilo próprio, compor e narrar a sua história.

Outros indícios lançados no romance sugerem que, na organicidade do sistema narrativo, o 'Ntoni é a fonte do argumento desenvolvido pelo narrador verista. Desde a primeira vez em que os elementos do universo ficcional aparecem na narrativa, são introduzidos por artigos definidos, como se já fossem velhos conhecidos do narrador: a Providência fica "na encosta do areal, debaixo do lavadouro, perto da Concetta do tio Cola e da chalupa do patrão Fortunato Cipolla" ${ }^{19}$. Na descrição das personagens centrais, feita no prólogo, a preferência pelo emprego dos hipocorísticos revela os laços afetivos do relator com os familiares. Ainda na apresentação genealógica e da tradição da família, estão concentradas as informações essenciais que o avô, como depositário da história familiar, transmitiu ao neto. O 'Ntoni é o único que tem motivos e condições para contar a história dos Malavoglia, e o faz, justamente porque, depois de todas as desditas que recaíram sobre eles, não pode mais permanecer na sua terra, com sua família; então, só lhe resta a possibilidade de reviver a história da sua vida por meio de sua narração.

A construção da máscara do 'Ntoni e a representação da trajetória de vida da personagem estabelecem um estreito vínculo intertextual com a Odisséia, e mais especificamente com a imagem de Ulisses, pela carnavalização do herói épico.

O 'Ntoni ia passear no mar todo o santo dia e cabia-lhe caminhar com os remos, arruinando a espinha. Porém, quando o mar

\footnotetext{
${ }^{217}$ Idem, p. 331(as duas citações).

${ }^{218}$ Idem, p. 13.

${ }^{219}$ Os Malavoglia, p. 13.
} 
estava bravo, querendo engolir de um trago a eles, a Providência e tudo, aquele rapaz tinha uma coragem maior do que o mar.

O sangue dos Malavoglia! dizia o avô; e era preciso vê-lo na manobra, com o vento a assobiar-Ihe nos cabelos, enquanto a barca saltava sobre os vagalhões como um mugem no cio. (р. 175)

Os atributos de Ulisses marcam a personagem do romance, no entanto, como se trata de uma representação paródica, a sua imagem refrata-os somente na medida exata da intenção de desvelar o seu reverso. Nas circunstâncias da contemporaneidade, as qualidades míticas do herói têm pouca serventia, pois não se mostram ajustadas às necessidades práticas da vida. Tome-se como exemplo, o fato de que, na realidade de Trezza, a morte no mar é sinal de bravura, pois "o mar é cruel e o marujo morre no mar"220, arriscando-se, num "jogo de desesperados", em troca de "algumas arrobas de peixe"221; já para Ulisses essa é uma "morte mesquinha"222, porque o herói épico deve morrer na batalha, por uma grande causa. Novamente, pode-se perceber o estilo firme do narrador verista, que estabelece o princípio de construção das personagens, a partir da destituição dos atributos dos mitos por ela recuperados.

A tempestade narrada no capítulo $X$, que apanha de surpresa a Providência em alto mar, com o patrão 'Ntoni, o 'Ntoni e o Alessi dentro, carnavaliza as diversas tormentas que Ulisses enfrenta no retorno a Ítaca, especialmente aquela em que está na jangada construída por ele mesmo, para sair da ilha de Calipso ${ }^{223}$. Os elementos, as circunstâncias, as ações, o ritmo e a intensidade dramática do episódio épico inspiram o do romance. Comparem-se alguns trechos de um e outro:

[...] - É a mudança do tempo! dizia ele, sinto isto nos ossos.

De repente, tinha escurecido tanto, que não se via mais nada, nem praguejando. Somente as ondas, quando passavam perto da Providência, luziam como se tivessem olhos e quisessem engoli-la; e

${ }^{220}$ Os Malavoglia, p. 77.

${ }^{221}$ Idem, p. 179.

${ }^{222}$ Cf. Homero, Odisséia, p. 66.

${ }^{223}$ Idem, pp. 66-70. 
ninguém ousava abrir a boca, no meio ao mar, que mugia até onde havia água.

- Não me sai da cabeça, disse de repente o 'Ntoni, que esta noite vamos ter de entregar ao diabo a pesca que fizemos. [...]

Ouvia-se o vento sibilar na vela da Providência, e o cordame, que soava como uma corda de violão. De improviso, o vento pôs-se a silvar como a locomotiva da estrada de ferro, quando sai do túnel do monte, acima de Trezza, e veio um vagalhão, sem se saber de onde, que fez a Providência chocalhar como um saco de nozes, lançando-a para o ar.

- Abaixar a vela! abaixar a vela! gritou o patrão 'Ntoni. Corta! Corta logo!

O 'Ntoni, com a faca entre os dentes, tinha-se agarrado ao mastro, como um gato, e, de pé na borda para fazer contrapeso, ficou suspenso sobre o mar, que rugia por debaixo dele, querendo engoli-lo.

- Segure firme! segure firme! gritava-lhe o avô em meio ao barulho das ondas que queriam arrancá-lo dali, e lançavam a Providência e o resto para o ar, fazendo a barca dobrar-se toda para um lado, que, dentro, estavam com água até os joelhos. - Corta! corta! repetia o avô. [...]

De repente, a vela caiu de vez, de tão tesa que estava, e o 'Ntoni recolheu-a num relance e arriou-a bem rente. [...]

A barca endireitou-se, depois de ter dado um grande salto daí, continuou a fazer cabriolas sobre as ondas.

[...] a Providência começou a ressaltar sobre a crista das ondas, curvada para um lado como uma ave ferida. Os Malavoglia mantinham-se todos de um lado, aferrados à borda; naquela hora ninguém respirava, pois quando o mar fala daquele jeito não se tem coragem de abrir a boca. [...]

Nesse momento, ouviu-se um estalido: a Providência, que antes tinha-se inclinado para um lado, ergueu-se como uma mola, e por pouco não atirou todos no mar; a verga, junto com a vela despencou sobre a barca, quebrada como um fio de palha. (Os Malavoglia, pp.180-83) 
Dito isso, ajuntou nuvens, empalmou o tridente e turbou o mar. Movimentou todo o ímpeto dos ventos de todos os rumos e cobriu de nuvens a um tempo a terra e o mar; a noite calou do céu. Juntos, precipitaram-se Euro e Noto e mais Zéfiro violento e Bóreas, filho do Éter, que rolava um vagalhão enorme.

Então se afrouxaram a Odisseu os joelhos e o coração quebrantado, disse a sua alma intrépida:

- Ai de mim, desventurado! Que me acontece agora por último? [...]

Enquanto assim falava, um grande vagalhão desabou do alto sobre ele, com tremenda violência, fazendo girar a jangada; ele soltou as mãos do leme e foi projetado a distância; terrível tufão de ventos confundidos veio partir-lhe o mastro ao meio; a vela e a antena foram cair longe no mar. A grande vaga manteve Odisseu submerso longo tempo [...] Nem assim, extenuado como estava, se esqueceu da jangada; arrojando-se entre as vagas, agarrou-se a ela e sentou-se no meio para não achar na morte o seu fim.

A vaga imensa, ao sabor de seu curso, a carregava de um lado para outro. Como, nas campinas, no fim do estio. Bóreas empurra, para cá e para lá, os cardos que cerradamente se estreitam, assim a tocavam os ventos [...]

Posidão, que o solo estremece, ergueu, emborcado, um vagalhão enorme, terrível e medonho, e arrojou-o sobre Odisseu. Tal como o vento impetuoso agita um montão de palhas secas e as dispersa em todos os sentidos, assim espalhou a vaga os longos fustes da jangada. Odisseu, porém, escanchou-se num dos troncos, como se montasse um cavalo de sela [...] (Odisséia, pp. 66-68)

Ao final, os Malavoglia são salvos por São Francisco, que os ouve, enquanto vai "pela borrasca em socorro de seus devotos" e estende "o seu manto sobre a Providência, justamente quando estava prestes a se arrebentar" $^{224}$. O episódio resolve-se de maneira muito semelhante ao da

${ }^{224}$ Os Malavoglia, p. 184. 
Odisséia, em que a deusa Ino dá a Ulisses um véu imortal, para que o estenda sobre o peito e, assim, não receie "nenhum dano nem a morte" ${ }^{225}$. Entretanto, antes que o santo acudisse a Providência, o patrão 'Ntoni já tinha sido atingido pelo mastro partido, e escapa da morte por um triz:

O avô jazia estendido no fundo do barco, com a cabeça quebrada. $O$ 'Ntoni encontrou-o, por fim, às apalpadelas, e achou que estivesse morto, porque não respirava, nem se mexia. (p. 184)

Nessa tempestade, dá-se a morte simbólica do patriarca e conclui-se o ritual de passagem da sucessão familiar, para o 'Ntoni e o Alessi. Os destinos do neto primogênito e do caçula representam as únicas possibilidades de continuação dos Malavoglia: a saída pela estrada e a reentrada na casa da nespereira. As duas opções, que a princípio aparentam ser atitudes opostas (emigração e permanência), propõem, de fato, o retorno às raízes. A saída do 'Ntoni, rebelde e aventureiro, simula a retomada da tradição dos primeiros antepassados, os Toscano, que emigraram da Península para a Sicília. A casa da nespereira do Alessi, que era "o avô escrito e borrado"226, é uma reprodução adaptada do modelo do patrão 'Ntoni. O caçula é o protetor da tradição familiar $^{227}$, e desde pequeno se prepara para cumprir seu encargo:

O Alessi, abraçado aos joelhos, como o avô, perguntava à Nunziata:

- Quer se casar comigo, quando eu crescer?

- Ainda temos tempo; respondia ela.

- Sim, tempo nós temos, mas é melhor pensar nisso agora, assim eu saberei o que devo fazer. Primeiro é preciso casar a Mena e a Lia, quando ela crescer. [...] É preciso ainda comprar a barca; a barca nos ajudará a comprar a casa. $O$ avô gostaria de ter outra vez a da nespereira, e eu também faria muito gosto, porque saberia por onde andar de olhos fechados, mesmo de noite, sem bater o nariz; tem o quintal grande para os apetrechos e em dois pulos estamos na

\footnotetext{
${ }^{225}$ Homero, Odisséia, p. 67.

${ }^{226}$ Os Malavoglia, p. 15.

${ }^{227}$ O nome Alessio significa "o protetor", "o defensor".
} 
praia. Depois, quando minhas irmãs estiverem casadas, o avô virá morar conosco e lhe daremos o quarto grande do quintal, onde bate o sol; assim, quando não puder mais ir ao mar, o pobre velho, ficará à porta que dá para o quintal, e no verão terá perto dele a nespereira, para lhe dar sombra. Nós ficaremos com o quarto da horta, você gosta? e teremos por perto a cozinha; assim, você terá tudo à mão, não é verdade? Quando meu irmão 'Ntoni voltar, nós o daremos a ele e iremos para o sótão. Você só terá que descer a escadinha para estar na cozinha ou na horta. (p. 241)

Todavia, as coisas não saem de acordo com o seu plano - a barca, que já parecia um "chinelo velho" quando foi arrematada pelo tio Crocifisso, não é mais recuperada; a Mena e a Lia não se casam; o avô morre; e 'Ntoni, o filho pródigo, não volta para ficar.

As condições de vida na província siciliana da Itália recém-unificada encerram as perspectivas existenciais. A marca histórica da miséria recai sobre a comunidade de Aci Trezza, fechando ainda mais o horizonte da aldeia, enquadrado "fra due zolle"228. Os pescadores têm que se aventurar cada vez mais ao longe, "agora que no povoado havia tantos barcos que varriam o mar"229. As moças se casam com os velhos - como a Sara, com o Menico Trinca, que era viúvo com seis filhos pequenos; a Barbara, com o patrão Fortunato Cipolla, que mais parecia o seu avô; e a Vespa, com o tio, o Campana di Legno -, pois os "maridos andam escassos, com esse recrutamento do diabo que leva embora todos os rapazes da aldeia" ${ }^{230}$. Os jovens agem como se "já tivessem cabelos brancos"231, porque "viram muitas desgraças" e tomam juízo desde cedo, como diz o patrão 'Ntoni. Em suma, não há renovação. No sistema econômico depauperado, o contrabando passa a ser o principal meio de subsistência da comunidade; e, ironicamente, essa sociedade, arraigada a valores tradicionais e ideais elevados do passado, vê-se dominada pela contravenção e vivendo na ilegalidade.

${ }^{228}$ G. Verga, "Fantasticheria”, p. 147.

${ }^{229}$ Os Malavoglia, p. 175.

230 Idem, p. 168.

${ }^{231}$ Idem, p. 241. 
Para o Ulisses de Verga não existe a possibilidade do regresso feliz à terra natal. Ao contrário do herói grego, que, depois de vencer todas as adversidades e inimigos, é abençoado por Palas Atenas, em sua casa, e recompensado com a "paz para o futuro"232; o 'Ntoni, "que tinha tido coragem suficiente" para abandonar a sua casa, "esfaquear dom Michele e meter-se em enrascadas" ${ }^{233}$, vê-se numa situação bem diferente quando retorna:

[...] a Mena disse-Ihe, completamente perdida: - Está indo embora?

- Estou! respondeu o 'Ntoni.

- E para onde vai? perguntou o Alessi.

- Não sei. Vim para vê-los. Mas desde que estou aqui, a sopa me desceu como veneno. Além disso, não posso ficar, pois todos me conhecem, e por isso é que vim de noite. Irei para longe, onde possa ganhar meu pão, e ninguém saberá quem sou.

Os outros não se atreviam a abrir a boca, porque sentiam o coração apertado num torno e entendiam que ele fazia bem em falar assim.

(pp. 328-29)

Tal como o rei de Ítaca, o 'Ntoni volta para Trezza com a aparência de um mendigo:

Uma vez, tarde da noite, o cachorro começou a latir, por detrás da porta do quintal, e o próprio Alessi, que foi abrir, não reconheceu o 'Ntoni, que voltava com o cesto debaixo do braço, tão mudado estava, coberto de poeira e a barba comprida. Quando entrou e foi se sentar num cantinho, quase não ousavam fazer-lhe festa. Ele não parecia mais o mesmo, e ficava olhando as paredes em volta, como se nunca as tivesse visto; até o cachorro latia para ele, como se fosse um estranho. Puseram-Ihe a tigela entre os joelhos, porque estava com fome e sede, e ele comeu em silêncio a sopa que Ihe

\footnotetext{
${ }^{232}$ Cf. Homero, Odisséia, p. 289.

${ }^{233}$ Os Malavoglia, p. 239.
} 
deram, como se não tivesse recebido dádiva de Deus durante oito dias, com o nariz metido no prato [...] (p. 328)

No entanto, aquilo que para Ulisses é parte de um ardil, que a deusa protetora planejara para expulsar os pretendentes à mão de Penélope de sua casa; para o 'Ntoni é a mais dura realidade, e motivo de vergonha perante a família e toda a aldeia.

As forças históricas atuantes solapam os princípios fundamentais da estrutura social da aldeia siciliana, endurecendo as condições de vida, virando de ponta cabeça os padrões axiológicos e minando as relações humanas. No quadro contemporâneo, os atributos heróicos do 'Ntoni, um rapaz "muito bem feito", que tem "bom coração" e "uma coragem do tamanho do mar"234, não representam mais nada.

- Adeus, repetiu o 'Ntoni. Veja como eu tinha razão em partir! aqui não posso ficar. Adeus, perdoem-me todos vocês. (p. 332)

${ }^{234}$ Os Malavoglia, pp. 16, 188,175 (respectivamente). 


\section{BIBLIOGRAFIA GERAL}

\section{OBRAS DE GIOVANNI VERGA}

I Malavoglia. Roma, Editori Riuniti, 1982.

Os Malavoglia. Tradução de Aurora Fornoni Bernardini e Homero Freitas de Andrade, São Paulo, Ateliê Editorial, 2002.

Tutte le novelle - Le opere di Giovanni Verga (a cura di Lina e Vito

Perroni). v. I, Milano, A. Mondadori Editore, 1940.

Mastro-don Gesualdo. Milano, II Saggiatore, 1979.

Lettere a Luigi Capuana (a cura di Gino Raya). Firenze, Felice Le Monnier, 1975.

\section{BIBLIOGRAFIA SOBRE GIOVANNI VERGA}

Dizionario biografico degli autori di tutti i tempi - Letterati, filosofi, scienziati, musicisti, storici, politici. vol. IV, Fabri, Bompiani, Milani, Fratelli Fabbri Editori, 1970. p. 394-6.

BUSETTO, Natale. "L'opera e l'arte di Giovanni Verga", in Archivio storico per la Sicilia orientale, fasc. II, Catania, Tipografia Zuccarello \& Izzi, 1932, pp. 289312.

CAPUANA, L. Verga e D’Annunzio. Bologna, Cappelli, 1972.

CROCI, Giovanni. "Introduzione e antologia critica" (Prefazione), in VERGA, Giovanni. I Malavoglia, Milano, Arnoldo Mondadori Editore,1978.

CONTINI, Gianfranco. Letteratura dell'Italia unita - 1861-1968. Sansoni Editore, 1994.

DEBENEDETTI, Giacomo. Verga e il naturalismo. Milano, Garzanti, 1976. 
GHIDETTI, E. Verga. Guida storico-critica. Roma, Editori Riuniti, 1979.

LANZA, Concetta Greco. "Invito alla lettura", in: Giovanni Verga: I grandi romanzi e tutte le novelle. Roma, Grandi tascabili economici Newton, 1992.

LUPERINI, R. Interpretazione di Verga. Roma, Savelli, 1975.

Verga e le strutture narrative del realismo. Padova, Liviana, 1976. Verga. Roma, Laterza, 1990.

"Verga o il viaggio impossibile", in Belfagor - rassegna di varia umanità, fascículo IV, Firenze, Casa Editrice Leo S. Olschki, 31/07/1989.

MASIELLO, Vitilio. Verga tra ideologia e realtá. Bari, De Donato, 1972.

MEROLA, Nicola. Giovanni Verga. Teramo, Lisciani \& Giunti Editori, 1993.

PETRONIO, Giuseppe. L'attivitá letteraria in Italia. Milano, Garzanti, 1990.

RAYA, Gino. Bibliografia verghiana (1840 - 1971). Roma, Ciranna, 1972.

RICCARDI, Carla. "Introduzione", in VERGA, Giovanni. Tutte le novelle. v. II, Milano, Arnoldo Mondadori Editore, 1984.

ROSA. Alberto Asor et alii. I/ caso Verga. IV edizione, Palumbo Editore, 1975.

RUSSO, Luigi. Gli scrittori d'Italia - storia della letteratura italiana. v. II, Firenze, G.C. Sansoni Editore, 1951.

SANGUINETI, Edoardo. "Cronologia della vita e delle opere" (Prefazione), in VERGA, Giovanni. I Malavoglia, Roma, Editori Riuniti, 1982.

SANTANGELO, G. Storia della critica verghiana. Firenza, La Nuova Italia, 1969.

SAPEGNO. Disegno storico della letteratura italiana. Firenze, La nuova Italia, 1973.

SCRIVANO, Riccardo. La narrativa di Giovanni Verga - appunti per le lezioni di letteratura italiana. Roma, Bulzoni Editore, 1981.

SICILIA, Francesco (org.) et alii. Giovanni Verga - Una biblioteca da ascoltare. Roma, Teatro dei Dioscuri, 13 aprile - 31 maggio 1999, Ministereo per i beni e le attivitá culturali - Edizioni de Luca.

SIMIONI, Corrado. "Introduzione", in VERGA, Giovanni. I Malavoglia. Milano, Arnoldo Mondadori Editore,1978.

SPINAZZOLA, V. Verismo e positivismo. Milano, Garzanti, 1977. 


\section{OBRAS DE TEORIA LITERÁRIA E OUTRAS}

Dicionário eletrônico Houaiss da língua portuguesa, versão 1.0, 2001.

Dictionnaire encyclopédique des sciences du language, Ducrot e Todorov, Seuil, 1972.

Dictionary of Literary terms, The concise Oxford, Chris Baldick, Oxford reference, 1990.

Dizionario della lingua italiana, G. Devoto, G. C. Oli, Firenze, Le monnier, 1971.

Dicionário da mitologia grega, Ruth Guimarães, São Paulo, Cultrix, Instituto nacional do livro - MEC, 1972.

Dicionário patrístico e de antiguidades cristãs. Tradução de Cristina Andrade, organização de Angelo Di Berardino, Petrópolis, Vozes, 2002.

Dictionnarie des symboles - mythes, réves, coutumes, gestes, formes, figures, couleurs, nombres. Jean Chevalier, Alain Gheerbrant, Robert Laffont/ Jupiter, 1982. Vocabulaire technique et critique de la philosophie, Société Française de Philosophie, 1960.

AUBRETON, Robert. Introdução a Homero. São Paulo, Difusão européia do livro, EDUSP, 1968.

ADORNO, Theodor et alii. "A posição do narrador no romance contemporâneo", in: Textos escolhidos. Col. Os pensadores, São Paulo, Abril Cultural, 1980.

Notas de literatura I. Tradução Jorge de Almeida. São Paulo, Livraria Duas Cidades, Editora 34, 2003.

ARISTÓFANES. A greve do sexo (Lisístrata) e A revolução das mulheres. Tradução de Mário da Gama Kury, Rio de Janeiro, Civilização Brasileira, 1964.

As vespas - As aves - As rãs. Tradução de Mário da Gama Kury, Rio de Janeiro, Jorge Zahar Editor, 2004.

ARISTÓTELES. Poética. Os pensadores, tradução de Baby Abrão, São Paulo, Nova Cultural, 2000.

AUERBACH, Erich. Mimesis. A representação da realidade na literatura ocidental. São Paulo, Editora Perspectiva, 1971. 
AYMARD, Maurice e GIARRIZZO, Giuseppe (org.) Storia d'Italia: Le regione dall'Unità a oggi - La Sicilia. Torino, Giulio Einaudi editore, 1987.

BAKHTIN, Mikhail. Estética da criação verbal. Tradução de Paulo Bezerra, São Paulo, Martins Fontes, 2003. Marxismo e filosofia da linguagem - Problemas fundamentais do método sociológico na ciência da linguagem. Tradução de Michel Lahud e Yara Frateschi Vieira, São Paulo, Editora HUCITEC, 1999.

Questões de literatura e de estética (A teoria do romance). Tradução de Aurora Fornoni Bernardini, José Pereira Jr, Augusto Góes Jr, Helena Spryndis Nazário, Homero Freitas de Andrade, São Paulo, Editora HUCITEC, Fundação para o desenvolvimento da UNESP, 1988.

BARTHES, Roland. "O efeito do real", in Literatura e Semiologia (Novas perspectivas em comunicação, $n^{\circ}$ 3). Rio de Janeiro, Vozes, 1972.

BENJAMIN, Walter et alii. "O narrador. Considerações sobre a obra de Nikolai Leskow", in Textos escolhidos. Col. Os Pensadores, São Paulo, Abril cultural, 1980, pp. 57 a 74

BONET, Carmelo M. El realismo literario. Buenos Aires, Editorial Nova.

BREA, L. Bernabò. Sicília. Lisboa, Editorial Verbo, 1972.

CANDIDO, Antonio et alii. A personagem de ficção. São Paulo, 1972. Literatura e sociedade. 8 ed., São Paulo, T. A. Queiroz Editor, 2000. "O mundo-provérbio", in VERGA, Giovanni. Os Malavoglia. Tradução de Aurora Fornoni Bernardini e Homero Freitas de Andrade, São Paulo, Ateliê Editorial, 2002.

CARPEAUX, Otto Maria. História da literatura ocidental. v. 6, Rio de Janeiro, Alhambra, 1982, p. 1.596-1.599.

CAROCCI, Giampiero. Storia d'Italia dall'unità ad oggi. Milano, Feltrinelli, 1975.

CHKLÓVSKI, Victor et alii. "Sobre a teoria da prosa" e "A arte como procedimento", in Teoria da literatura. Formalistas russos. Porto Alegre, Globo, 1971.

CIACERI, Emmanuele. "Siculi e greci nella storia più antica della Sicilia", in Archivio storico per la Sicilia orientale, fasc. II, Catania, Tipografia Zuccarello \& Izzi, 1932, pp. 3-32. 
CICCAGLIONE, Federico. "La Sicilia nella formazione e nello sviluppo del sentimento nazionale italiano", in Archivio storico per la Sicilia orientale, fasc. II, Catania, Tipografia Zuccarello \& Izzi, 1932, pp. 210-221.

DE SANCTIS, Francesco. Storia della letteratura italiana, a cura di N. Gallo. Torino, Einaudi, 1958.

DUBOIS, J. et alii. Retórica geral. Tradução de Carlos Felipe Moisés, Duílio Colombini e Elenir de Barros, São Paulo, Cultrix, EDUSP, 1974.

EISENSTEIN, Serguei. Reflexões de um cineasta. Tradução de Gustavo A. Doria, Rio de Janeiro, Zahar Editores, 1969.

GENETTE, Gerard. Discurso da narrativa. Tradução de Fernando Cabral Martins, Lisboa, Veja, 1972.

GROSSER, Hermann. Narrativa - Manuale / Antologia. Milano, Principato, 1985.

HAUSER, Arnold. Historia social de la literatura y el arte III - naturalismo e impresionismo bajo el signo del cine. Madri, Ediciones Guadarrama, 1969.

HOMERO. Odisséia. Tradução de Jaime Bruna, São Paulo, Cultrix, 1968.

JAKOBSON, Roman. "Do realismo artístico", in: Teoria da Literatura - Formalistas russos. Porto Alegre, Globo, 1971.

LAUSEBERG, Heinrich. Manual de retórica literaria - fundamentos de una ciencia de la literatura. Tradução de José Pérez Riesco, Madri, Bib. Romanica Hispánica e Editorial Gredos, 1966.

LIBERTINI, Guido. "Catania nell'età bizantina", in Archivio storico per la Sicilia orientale, fasc. II, Catania, Tipografia Zuccarello \& Izzi, 1932, pp. 242-264.

LIKHATCHÓV, Dmitri S. "Sobre el realismo y su definición", in Textos e contextos. Havana, Editora Arte y Literatura, 1985.

LUCKÁS, Georg. Teoria do romance. Lisboa, Editorial Presença, s/d. Ensaios sobre literatura. Rio de Janeiro, Civilização Brasileira, 1965. Materiales sobre el realismo. Barcelona, Grijalbo, 1977.

LUCKÁS, G., BAKHTIN, M. et alii. Problemi di teoria del romanzo. Torino, Einaudi, 1976.

MACHADO, Irene A. A voz e o romance. A prosaica dialógica de Mikhail Bakhtin. Rio de Janeiro, Imago/Fapesp, 1995.

MAGRI, Domenico. Storia della letteratura italiana. Torino, Società Editrice Internazionale, 1953, p. 357-360. 
MELETÍNSKI, Eleazar Mosséievitch. Os arquétipos literários. Tradução de Aurora Fornoni Bernardini, Homero Freitas de Andrade e Arlete Cavaliere, São Paulo, Ateliê Editorial, 1988.

PROPP, Vladímir. Comicidade e riso. Tradução de Aurora Fornoni Bernardini e Homero Freitas de Andrade, São Paulo, Ática, 1992.

ROSA, Alberto Asor. Storia della letteratura italiana. Firenze, La Nuova Italia, 1989.

ROSENFELD, Anatol. Texto e contexto. São Paulo, Editora Perspectiva, 1976.

SALINARI, C. e RICCI, C. Storia della letteratura italiana. Bari, Laterza, 1982.

SALVATORELLI, Luigi. Sommario della storia d'Italia - dai tempi preistorici ai nostri giorni. Torino, Einaudi, 1982.

SCHNAIDERMAN, Bóris. Turbilhão e semente: ensaios sobre Dostoiévski e Bakhtin. São Paulo, Livraria Duas Cidades, 1983.

SCHNERB, Roberto. O século XIX - O apogeu da civilização européia. Col. História geral das civilizações, São Paulo, Difusão européia de livros, 1961.

SQUAROTTI, Giorgio B. (org.) Literatura italiana - linhas, problemas, autores. São Paulo, Nova Stella, Istituto Italiano di Cultura, EDUSP, 1989, p. 451-454.

TODOROV, T. e DUCROT, O. Dicionário enciclopédico das ciências da linguagem. São Paulo, Perspectiva, 1977.

TYNIÁNOV, lúri. "Dostoevskij e Gogol': per uma teoria della parodia", in: Avanguardia e Tradizione. Tradução italiana de Sergio Leone, Bari, Dédalo Libri, 1968.

VILLARI, Rosario. (org.) II sud nella storia d'Italia - antologia della questione meridionale. Bari, Laterza editori, 1961.

WELLEK, René. História da crítica moderna 1750-1950 - o final do século XIX. São Paulo, Editora Herder, EDUSP, 1972.

Referências de sítios da Internet consultados:

\begin{tabular}{|l|l|}
\hline$\bullet$ http://biografie.leonardo.it & $\bullet$ www.grifasi-sicilia.com \\
\hline$\bullet$ http://it. wikipedia.org & $\bullet$ www.italiadonna.it \\
\hline$\bullet$ www.accademiadellacrusca.it & $\bullet$ www.italialibri.net \\
\hline$\bullet$ www.bandieraitaliana.com & $\bullet$ www.letteratour.it \\
\hline$\bullet$ www.cademeusanto.com.br & $\bullet$ www.liberliber.it \\
\hline$\bullet$ www.cataniaonline.it & $\bullet$ www.luchinovisconti.net \\
\hline
\end{tabular}




\begin{tabular}{|l|l|}
\hline$\bullet$ www.carboneria.it & $\bullet$ www.parchiletterari.com \\
\hline$\bullet$ www.cronologia.it & $\bullet$ www.regione.sicilia.it \\
\hline$\bullet$ www.demauroparavia.it & $\bullet$ www.santiebeati.it \\
\hline$\bullet$ www.garzantilinguistica.it & $\bullet$ www.sipario.it \\
\hline$\bullet$ www.giovannigiolitti.it & $\bullet$ www.storiafilosofia.it \\
\hline$\bullet$ www.girodivite.it & $\bullet$ www.volpin.it \\
\hline
\end{tabular}

